\title{
THE INTERACTION BETWEEN PHOTOVOLTAIC MATERIALS AND BUILDING FORMS
}

\author{
By \\ Liming Qiu \\ Bachelor of Engineering, Zhengzhou University,1998 \\ A thesis project \\ presented to Ryerson University \\ in partial fulfillment of the \\ requirements for the degree of \\ Master of Architecture \\ In the Program of Master of Architecture
}

Toronto, Ontario, Canada, 2009

(C) Liming Qiu 2009 
I hereby declare that I am the sole author of this thesis.

I authorize Ryerson University to lend this thesis to other institutions or individuals for the purpose of scholarly research.

\section{Liming Qiu}

I further authorize Ryerson University to reproduce this thesis by photocopying or by other means, in total or in part, at the request of other institutions or individuals for the purpose of scholarly research.

Liming Qiu
The interaction between photovoltaic materials and building forms

By Liming Qiu, M. Arch., Master of Architecture, Ryerson University, 2009

\section{Abstract}

There is an intrinsic relationship between photovoltaic materials and building forms: although there are numerous imaginations and concepts about buildings integrated photovoltaic materials. The relationship between these two components needed to be identified and examined in the process of architectural decision making

This thesis explores the relationship between photovoltaic materials and building forms in particular geographical and climatic environments through case studies and then proposes an architectural design project. Based on the research suggestion, the design illustrates how a recreational facility adopts an approximate building form for photovoltaic integration and how the concept is developed. Some implications and principle for solar design are summarized in the final chapter. 
Table of Contents

Abstract iii

I would like to thank my thesis supervisor Dr. Mark Gorgolewski for his guidance and encouragement throughout the semester. I also thank Professor Colin Ripley and Dr. Alan Fung for their valuable suggestions. I am especially grateful to Sheena Sharp for her invaluable time and remarks on my thesis and Mila Aleksic who contributed her raw data for solar pane calculation. Finally I thank my parents and friends who have always supported my work. You have all inspired me and encouraged me to learn.

\section{Acknowledgements iv}

1. Introduction 1

1.1 Problem statement $\quad 2$

1.2 Research methodology 3

1.3 Literature review $\quad 4$

2. Interactions between photovoltaic materials and building forms

2.1 Why study photovoltaic materials and building forms 6

2.2 The architectural interpretation of photovoltaic materiality $\quad 7$

2.2.1 Form, size and pattern 7

2.2.2 Transparency and color 8

2.2.3 Manufacturing process, efficiency and cost

2.3 The evolution of photovoltaic building forms

2.3.1 Form making towards efficiency and optimization

2.3.2 Form making towards aesthetic and cultural expression

2.3.3 Three approaches to creative design 24

2.4 Aesthetic and cultural expression in photovoltaic buildings

2.4.1 Envelop of the future: Smart Wrap ${ }^{\mathrm{TM}} 31$

2.4.2 Zero Energy Media( The Green Pix) 33

2.4.3 Expression of Particular Cultures (The Japanese Sanyo Solar Ark) 


\section{List of Tables}

Table 1

2.6 Conclusion 50

3. A recreational facility integrated with photovoltaic technologies

3. 1 Overview 53

3.2 Solar shading analysis

3.3 Site analysis 62

3.4 Design objectives 62

3.5 Form exploration 66

3.6 Architectural intervention 70

4. Principles and conclusions 95

4.1 Principles for the building forms integrated with photovoltaic materials

4.2 Summary of the research 99

4.3 Limitations of the study 99

List of Tables vii

List of Figures vii

Appendices 101

References 108
Table 2

Table 3

Table 4

Dimensions and architectural properties of selected solar panels

Photovoltaic Applications of Different Building Types

Technical and Architectural Implications for Photovoltaic Materials

Sunrise and Sunset Times for Toronto Eastern Time Zone

List of Figures

Figure 1 The Greenpix, facade integrated with photovoltaic cells and an LED lighting system. Retrieved September 10, 2008, from PHOTON International, p.146.

Figure 2 Pattern illustrating how transparency can be achieved through a matrix of photovoltaic cells (Drawn by the author)

Figure 3 Austin Convention Center: thin film photovoltaic modules installed on the facade of south entrance. Retrieved November 10, 2008, from http://www. concierge. com/images/destinations/destinationguide/usa+canada/usa/texas/austin/austin_0 02p.jpg

Figure 4. A vacation house in Ferienhaus Bartholoma-Park, the roof is a completely integrated photovoltaic system. Retrieved November 10, 2008, from PVdatabase website, http://www.pvdatabase.org/projects_view_details.php?ID=261

Figure 5 Down 2000 Zero emission houses with photovoltaic awnings on roofs. The space underneath the roof is not impacted by the photovoltaic installation. Retrieved November 10, 2008, from BEAR Architecten, www.bear.nI

Figure 6 Solar Fabrik, Freiburg, Germany. The east view of this Europe's first zeroemissions solar module factory. Retrieved November 10, 2008, from http:// www.solar-fabrik.com/fileadmin/user_upload/pressebilder/fabrik/ Aussen1.JPG

Figure 7 Transformation of building forms to satisfy technical requirements (Drawn by the author) 
Figure 8 Mont - Cenis - Academy in Herne Sodingen, Germany. Retrieved November 14, 2008, from International Energy Agency ( IEA ) Photovoltaic Power Systems Programme: $h$ ttp://www.iea-pvps.org/cases/deu_01.htm

Figure 9 Solarcafé "Sonnenzeit" in Kirchzarten,Germany. Retrieved November 10, 2008, from PVdatabase, http://www.pvdatabase.org/

Figure 10 Canoga Park Branch Library in Los Angles. Retrieved November 12, 2008, from http://archrecord.construction.com/projects/bts/archives/libraries/06_CanogaPark loverview.asp

Figure 11 Solarsiedlung in German, designed by Rolf Disch. Retrieved November 8, 2008 from $h$ ttp://greenlineblog.com/wp-content/uploads/2008/01/solarsiedlung-image07.jpg

Figure 12 San Diego Children's Museum, photos showing multiple pitched roofs integrated with photovoltaic and interior space (Photography by the author)

Figure 13 ShenZhen Floral Exhibition 2007 office building, perspective showing saw tooth roof integrated with oval shaped building form (Credit the photographer).

The diagram below illustrates the controversy of optimum orientation for passive solar design and active solar design (Drawn by the author)

Figure 14 Tobias Grau KG Office, designed by BRT Architeckten. Retrieved October 10 2008, from http://www.brt.de/start.htm/

Figure 15 Coney Island's Stillwell Avenue Terminal in New York, designed by Kiss + Cathcart Architects. Retrieved December 10, 2008, from http://www.kisscathcar t.com/stillwell.html

Figure 16 Oldenburg stadium EWE-Arena, cylinder shaped facade integrated with movable photovoltaic panels. Retrieved October 5, 2008, from Colt Group, http://www.colt group.com/projects/sports-stadia-leisure/ewe-arena/

Figure 17 London City hall, roof integrated with photovoltaic panels. Designed by Foster + Partners. Retrieved December 10, 2008, from http://www.london-se1.co.uk/news /imageuploads/1204815897_62.49.27.213.jpg

Figure 18 Three approaches to form-making in building integration of photovoltaic materials (Drawn by the author)

Figure 19 Turbulence house, designed by Steven Holl. The tilted roof is mounted with photovoltaic panels to optimize solar gain. The second floor houses a bedroom and a study area. Retrieved December 10, 2008, from http://www.stevenholl.com /project-detail.php?type $=$ houses\&id $=53 \&$ page $=0$

Figure 20 The tilted roof of Turbulence House covered by thin snow. Retrieved in November 20, 2008, from http://www.stevenholl.com/project- detail.php?type= houses\&id $=53 \&$ page $=0$

Figure 21 Heliotrop and its perspective, designed by Rolf Disch. Retrieved November 20, 2008, from http://www.rolfdisch.de/project. asp? $i d=45 \&$ sid $=-633635510$

Figure 22 Steinhude Sea Recreation Facility. Retrieved November 20, 2008, from http:// www.volume5.com/rstout/html/architect_randall_stout_interv1.html

Figure 23 Exterior views of SmartWrap ${ }^{\mathrm{TM}}$. Retrieved November 10, 2008, from Kieran Timberlake Associates, http://www.kierantimberlake.com/research/smartwrap_ research_1.html

Figure 24 The Greenpix, facade integrated with photovoltaic cells and LED lighting system Retrieved September 20, 2008, from PHOTON International, p.146.

Figure 25 Vlatko Ceric is working on his art (left), the algometric works entitled "Agglomeration" by Vlatko Ceric (right). Retrieved November 24, 2008, from his personal website http://www.vceric.net/

Figure 26 A diagram illustrating how the Greenpix's photovoltaic facade is integrated LED lighting system (Drawn by the Author)

Figure 27 The Japanese Sanyo Solar Ark. Retrieved November 24, 2008, from Sanyo Electric Co. Ltd., http://www.sanyo.com/solar/solarark/index.html

Figure 28 Form analysis of the Sanyo Solar Ark (Drawn by the author). Photos retrieved November 10, 2008 from http://www.genjimono.cn/bbs/showthread.php? 
threadid=8680, http://lh4.ggpht.com/_g2ogMZBczdw/R78pKg60 wnl/AAAAAAAA CrA/5RS4-toNAGk/DSC05372.JPG, and http://www.sanyo.com/solar/solarark lindex.html. Credit the photographer.

Morphological analysis of the Solar Ark (Drawn by the author)

Figure 30 The Canadian Museum for Human Rights (schematic design). Retrieved November 10, 2008, from http://canada.archiseek.com/news/2005/000115/ 1.html

Figure 31 Form study of Canadian Museum for Human Rights( CMHR) (Drawn by the author)

Figure 32 A diagram illustrating the relationship between photovoltaic annual electricity and geographical location (Drawn by the author)

Figure 33 This diagram illustrates the relationship between annual electricity generated by a specified photovoltaic panel and its spatial locations, defined by azimuth angles and slopes. The spectrum, divided into ten equal intervals, indicates the amounts of electricity from maximum to minimum, represented by blue and red squares respectively. The deeper blue the square is, the less electricity the photovoltaic panel generates (Drawn by the author).

Figure 34 Lux Nova or (true north), designed by Canadian stained glass artist Sarah Hall. Retrieved November 20, 2008, from http://www.sarahhallstudio.com/photo glass

Figure 35 Spinnereistrasse in Austria: façade integrated with thin film photovoltaic panels. Retrieved November 20, 2008, from http://www.stromaufwaerts.at/en/content popup referenz.php?rs $I D=94$

Figure 36 Efficiency-cost trade off for the three generations of solar technology: wafers, thin films, and advanced thin films (year 2003; cost in US\$). Redrawn and revised by the author. Source: Green, Martin A. (2006). Third Generation Photovoltaic materials. P3. Figure 1.2

Figure 37 The proposed site: Lamport Stadium recreational park located in west region of Toronto, Ontario Canada. Latitude of the site is $43^{\circ} 38^{\prime} 20.20$ " $\mathrm{N}$, longitude is $79^{\circ}$ 25'22.87" W
The simulation diagram of solar shadow showing the site has long hours of solar radiation without permanent shadow

Figure 40 The diagram and bar graph showing sunrise and sunset times (top left) and daily solar radiation (bottom left) for the proposed site and the area appropriate for photovoltaic materials (right). Data retrieved June, 2008 from RETScreen database and Sunrise and Sunset calculator of Time and Data AS

Figure 41 The diagram of circulation showing the site is surrounded by industrial and commercial buildings

Figure 42 Community centers in the neighbourhood

Figure 43 Demographic data and the map of community facilities

Figure 44 Comparison between different forms for photovoltaic materials

Figure 45 A diagram showing PV canopy, light wells, and the cubic form are integrated into one building

Figure 46 Diagrams showing a photovoltaic canopy accommodating a service block and flexible space for community use.

Figure 47 Diagrams showing the building accommodates different events

Figure 48 Conceptual diagrams showing the integration of the photovoltaic technologies, the cubic form and the structural columns functioning as light wells and a natural ventilation system

Figure 49 Master plan showing the integration of cubic form of the building and outdoor multifunctional green space

Figure 50 Space configurations showing that the building provides a large event space for flexible programs and the service block providing electrical room for photovoltaic technologies

Figure $51 \quad$ Floor plans of the service block

Figure 52 Long section AA looking north; the rooftop of service block on the left hand 
provides occupants with a cafeteria space and retractable seats are located against the walls of service block

Figure 53 The proposed steel truss structure, steel column system and their geometries

Figure 54 Various photovoltaic materials such as thin film panels and photovoltaic cells can be integrated onto the flat roof

Figure 55 Various photovoltaic materials such as flexible thin film sheets and tubular collectors can be integrated onto the flat roof

Figure 56 Elevations showing that the south and west facades are integrated with photovoltaic cells

Figure $57 \quad$ North elevation along King Street

Figure $58 \quad$ Facade integrated with solar cells

Figure 59 Roof details showing the façade and the roof are connected by a mechanical system

Figure 60 A night view of the building seen from King Street West, a spiral stair on the right is designed for photovoltaic roof maintenance

Figure 61 The building seen through the outdoor green space from Liberty Street

Figure 62 Parts of the building facade can be opened up to connect indoor and outdoo community activities, photovoltaic cells laminated on the tilted facade will be more efficient

Figure 63 A close view of the building facade opened up for community activities; photovoltaic cells laminated on the tilted facade will be more efficient

Figure 64 A view into the cafe area close to the facade- the shade of photovoltaic cells provides a dynamic visual effect

Figure 65 An aerial view of the building and the photovoltaic roof seen from the Liberty Street

\section{Introduction}

Through performing both technical and aesthetic functions photovoltaic technology is stirring the imagination of architects with its potential. How to achieve unity, harmony and creativity in architecture has become a major concern. A successful photovoltaic building design relies not only on synthesizing various building materials and space, but also on determining an appropriate building form on a larger scale. Through exploring the interaction between photovoltaic materials and building forms, this thesis aims at proving creative designs exist in photovoltaic integration.

Section Two reviews the history of photovoltaic technologies in contemporary architecture by identifying the primary aspects of photovoltaic materiality, technologies and the connection between building forms and photovoltaic modules. An analysis of the relationship between energy performance, building forms and space is examined with case studies that range from a cafeteria to a children's museum in various countries throughout the northern hemisphere.

Section Three proposes a design project that illustrates how photovoltaic technologies can be integrated into a recreational facility in Toronto, Ontario, Canada. The relationship between building functions, the geographical location, and photovoltaic technologies will be explored to demonstrate how design opportunities still exist for creating a distinctive photovoltaic building in spite of constraints.

The final chapter summarizes some principles of photovoltaic design derived from thesis research. 


\subsection{Problem Statement}

The research addresses practical problems and common questions for solar professionals. What is the fundamental concern in the design process of photovoltaic integration? Why and how should a creative photovoltaic building be designed? Where should a creative photovoltaic building be located?

These problems reflect a prevalent state of synthesizing and promoting photovoltaic materials as building materials in current architectural design. The answer to these questions is the inception of photovoltaic architecture.

The research explores the interaction between photovoltaic materials and building forms as the researcher argues there is an intrinsic relationship between them. A successful solution of photovoltaic integration relies on a thorough understanding and experience of both photovoltaic technologies and their relationship to building forms.

In the design project the thesis integrates, explores and tests the implications summarized in the first section. Based on the exploration, the thesis claims that the recreational facility, as one type of public building, can be integrated with photovoltaic technologies and materials creatively to promote solar energy. It goes on to show that discussing interaction associated with photovoltaic materials and building forms is one essential step in the process of decision making. The thesis builds a basis for building integration of photovoltaic materials through not only analysis, but practice.
1.2 Research methodology

The primary aim is to establish principles and strategies for creative architectural design in photovoltaic buildings with simple functions and energy demands. To meet these ends, the paper explores the interaction between relevant building forms and photovoltaic materials by analyzing the relationship between the energy output, building form and photovoltaic integration. The method followed is to analyze projects through case study before exploring their implications for architects in the process of design and decision making. Information collected is both quantitative and qualitative. Quantitative items are factors such as annual electricity generation, temperature and building areas. The qualitative items do not have precise measurement illustrated by difficulties in assembly, the ease of collaboration and geometric aesthetics. Case studies were chosen from various forms of literature including, but not limited to, journals, magazines, reliable websites and books.

The design project is used as a way of investigating practical issues of photovoltaic integration in a realistic context. In the design project, the procedure is presented in the following sections: Overview, Solar Shading Analysis, Site Analysis, Design Objectives, Form Exploration and Architectural Intervention. The first three sections provide this design project with concrete evidences while design objectives are achieved through form exploration and architectural intervention 


\subsection{Literature review}

Can photovoltaic technologies present opportunities for creative architectural design? Hermannsdorfer and Rüb (2005) state:

they [solar facilities] can enhance the architecture, accentuate it and distinguish it from the mass; they can express adaptation and transformation or modernity while at the same time preserving the traditional features" (p. 9).To demonstrate this, a German-Italian team conducted a research project, PVACCEPT, to improve the aesthetic design of photovoltaic materials, focusing on new applications of photovoltaic materials in existing or historic buildings.

Photovoltaic modules are generally used as surface materials. Thus both the materiality and technology of photovoltaic materials are critical aspects of creative architectural design. Johan Bettum (2002) stated "the focus on surface articulation is fundamentally linked to, even uniquely expressed as, a corresponding interest in materials and material technology" (p. 72) This perspective will assist architects discovering the aesthetic values of photovoltaic technologies on a two-dimensional level.

Besides the technology and materiality of photovoltaic materials, I believe the interaction between building forms and photovoltaic materials is one of the major aspects of creative architectural design. A discussion of the relationship between surface and architecture can be found in Bettum's article (2002):

in contrast to approaches based on types of topology or topography, current concern with surface articulation are subject to the possibilities and resistances of the surface as a three-dimensional material entity. The surface must therefore be conceptualized and designed with respect to its depth. (p. 25)

Bettum also suggests architects have to think of surface materials in both micro-scale and macro-scale. Material studies in micro-scale are limited to the individual characteristics of selective surface materials. Material studies in macro-scale investigate the optical, physical and scientific phenomena of materials in applications by observing and analyzing the connection between selected materials and other materials. Through macro and micro studies architects can better comprehend building materials by integrating architecturally innovative ideas with them
Many books have studied the micro features of photovoltaic materials. However, few documents contribute to material studies on a macro-scale. Most of them refer to the field only in an engineering manner therefore missing ample opportunities for creative form-making in photovoltaic integration, and for conveying architectural meaning through building forms.

Research into photovoltaic materials on a macro-scale uncovers opportunities for creative architectural design. Moreover, the paper intends to explore principles of creative photovoltaic integration by analyzing building form-making and relevant tradeoffs. 


\section{Interactions between photovoltaic materials and building forms}

\subsection{Why study photovoltaic materials and building forms}

Photovoltaic technologies and contemporary architecture have been interacting since the 1980s. Before that, photovoltaic technologies had come a long way since their first discovery in 1839 by French physicist Alexandre-Edmond Becquerel. From 1900 to 1970, scientists have explored the photovoltaic effect and its application in spacecraft. After the first application of photovoltaic technologies on earth in the 1970s, scientists and engineers started to experiment with integrating photovoltaic systems into buildings. Early applications of Building Integration of Photovoltaic (BIPV) systems dated back to the 1980s, when large photovoltaic plants were established in many advanced industrial countries, such as Germany, Japan, and the United States. Some European architectural firms, such as Kiss + Cathcart Architects, and Bear Architecten in Germany, engaged in BIPV research and design in the same period (Lugue \& Hegedus, 2003).

Photovoltaic technologies were "born" in a period when contemporary architecture was involved in complicated discourse and practice. On the one hand, the development of the post-modern architecture movement inspired many young architects. Material assemblage, construction detail and interior space in their practices were subversive. As Roth (2007) describes this period, "the pioneers of modern architecture in the 1920s and 1930s tried to create a wholly new idiom generated solely by functional use and structural systems. Their ascetic architecture was to make no statement other than to reveal itself "(p. 539). On the other hand, theoretical thinking on the preservation of classical tradition spread through Europe, America, and Asia (Fazio, Moffett, \& Woodhouse, 2008).

The diversity, however, left a dilemma for architects who were engaging with photovoltaic integration in buildings. The dilemma was whether photovoltaic integration conforms to rigid technical requirements or to artistic expression? Could photovoltaic buildings use the legacy from post-modernism, liberating building forms from technical restrictions? Could photovoltaic materials, integrated with architectural motifs, convey social and cultural meaning?

\subsection{The architectural interpretation of photovoltaic materiality}

Without knowledge of photovoltaic materiality, practical solutions for this dilemma cannot be achieved. To explore the transparency of photovoltaic materials, for instance, Architects need to understand photovoltaic mechanisms and physics of photovoltaic cells. Therefore, a brief review of photovoltaic materiality is presented before discussing this dilemma

Photovoltaic materials are evolving. Recently, crystalline silicon and thin-film have become two major technologies of the photovoltaic industry. The major difference in physical properties between these two photovoltaic technologies is their base materials. Unlike crystalline silicon cells that are produced from silicon wafer, thin film cells are printed on the film.

Their physical characteristics of both mainly refer to five aspects: transparency, colour, form, size and pattern. In addition, efficiency, cost, and manufacturing process are helpful to understand these features. There is no room in this thesis to discuss these aspects comprehensively; this brief introduction is intended to explain opportunities for creative architectural design in microscale before the following discussion on building forms and photovoltaic materials.

\subsubsection{Form, size and pattern}

Typical crystalline photovoltaic modules consist of crystalline cells. Usually, the crystalline cell size is approximately $150 \times 150 \mathrm{~mm}$; these cells are "glued" in transparent "sandwich" glass sheets. These panel types vary from $200 \times 200 \mathrm{~mm}$ to $2000 \times 3000 \mathrm{~mm}$. Some solar panel sizes and their relevant properties in selected manufacturing can be referenced in Table 1. Recently, a cut-to-size module prototype based on thin film technology was developed by PVACCEPT to meet architectural needs. These modules can be customized to specified design dimensions through trim and cutting (Hermannsdorfer \& Rüb, 2005). 
Patterns of crystalline silicon can render semi-transparent effects. This phenomenon, integrated by the artistic imagination, can create an expressive design. In a hotel complex in Beijing, Simone Giostra \& Partners used this method, combining it with LED technology to generate a striking façade (see Figure 1). Unlike crystalline silicon photovoltaic materials, the size of thin film photovoltaic materials depends on the base materials they use. There is no common industrial standard for this type of material, so architects have to contact manufacturers for detailed product information.

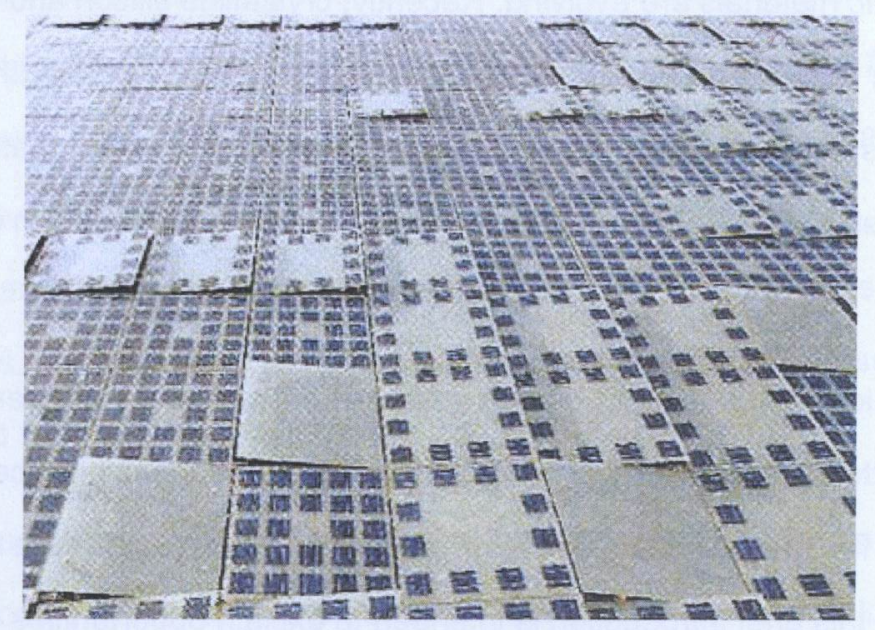

Figure 1. The Greenpix, facade integrated with photovoltaic cells and LED lighting system.

\subsubsection{Transparency and colour}

Manufacturers provide both opaque and semi-transparent photovoltaic products. Individual crystalline silicon cells are opaque, while thin film cells based on cadmium-telluride (CdTe) or copper-indium-diselenide (CIS) are semi-transparent. By arranging the pattern of crystalline silicon cells or changing the cells' shape, photovoltaic panels can have relative "transparency" in appearance. This optical phenomenon assists architects to apply opaque materials like photovoltaic cells to create translucent screens. Visual effects are determined by the distance and density of crystalline silicon cells (see Figure 2). However; creating semi-transparent effects interferes with the solar panels' area. The more transparent a surface with a given area is, the fewer its photovoltaic cells, and so the smaller amount of electricity these photovoltaic cells generate.

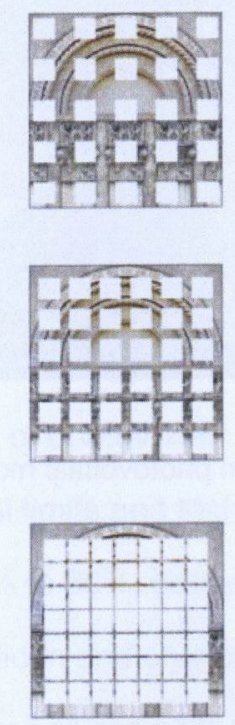

Figure 2. Pattern illustrating how transparency can be achieved through a matrix of photovoltaic cells.

The concept of translucency has been widely used in architecture in the last decades because of its social, technical, and psychological functions. Using transparent or translucent materials, architects can create exciting spaces, bringing light and view into a building's interior. As a result, architects give serious consideration to the transparent characteristics of building materials. Even in buildings integrated with photovoltaic materials, architects also consider this notion instinctively. Austin Convention Center is an example (see Figure 3). The central exhibition hall is surrounded by other spaces: lobbies, registration areas and circulation areas. Along the Trinity Street facade, the architects integrated thin-film panels into the building's curtain wall in order to reduce the stress that the building's volume brings to the street (Lawrence, 2007). One major disadvantage of making photovoltaic materials transparent is losing conversion efficiency of photovoltaic panels. However, these deep blue thin film panels can reduce overheating from their western orientation, producing energy from the sun's radiation. Its transparent facades also encourage people to explore dynamic activities happening in this building. 


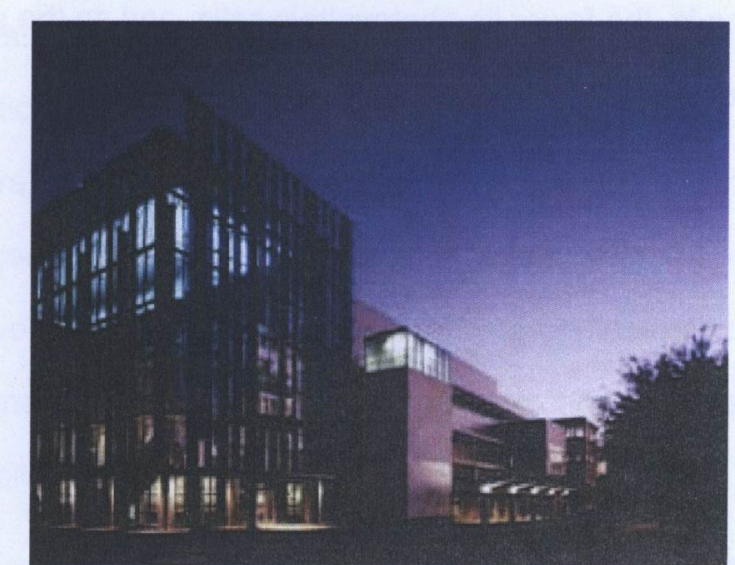

Figure 3. Austin Convention Center: thin film photovoltaic modules installed on the facade of south entrance.

Besides transparency, architects can also play with photovoltaic colours. However, the colour options of photovoltaic cells are limited because of their technical features (Hindrichs, 2007). Crystalline silicon cells range from deep blue to green, while "Thin film [cells] consisting of amorphous silicon or CIS are black in colour, CdTe cells have a greenish shimmer" ( Hermannsdorfer \& Rüb, 2005, p.41). An approach to modifying solar cells' colour is to alternate an anti-reflection layer of cells, but this will slightly reduce conversion efficiency. In addition, this method increases the cost of the solar cells because of the additional manufacturing process. (Hermannsdorfer \& Rüb, 2005)

\subsubsection{Manufacturing process, efficiency and cost}

The manufacturing process for photovoltaic cells is associated with the cost and technical characteristics of solar cells, presenting opportunities for creative architectural design. The manufacturing process for crystalline silicon cells is based on wafer technology in which cells are produced from ingots by trimming, sawing, diffusion, and screen-printing of contacts. Thin film technology is based on screen-printing. To achieve higher efficiency, one practical way in crystalline silicon technology is to increase the thickness of base materials. However, a disadvantage of this method is that thicker material not only increases cost but also reduces efficiency indirectly (Luque \& Hegedus, 2003, p.27). Though crystalline silicon technology is well established, thin film technology is more competitive because of its thinner base materials and faster manufacturing process.

The efficiency of photovoltaic systems influences the performance of photovoltaic cells, indirectly impacting on the market acceptance of photovoltaic systems. Generally speaking, whether a building is suitable for photovoltaic installation and what types of photovoltaic cells can meet energy goals depend on the efficiency and cost of photovoltaic products.

The ideal solar cell efficiency limit of photovoltaic cells has a maximum value of $95 \%$ (Tom, 2003). However, due to material limits and technical barriers, the best solar cell efficiency reported currently is from $3 \%$ to $30 \%$, depending on the technologies and materials (Tom, 2003). In addition, crystalline silicon and crystalline thin film modules are different in conversion efficiency; present crystalline silicon cells have $8-15 \%$ and thin film cells (CIGS) have approximately 3-20\% (Hindrichs, 2007).

Many factors can limit the efficiency of photovoltaic systems. For instance, silicon cells generate large amounts of heat as they convert sunlight to electricity, which lowers conversion efficiency. That is one reason why architects need to consider ventilation in integrating silicon photovoltaic panels into buildings. Another limitation on photovoltaic efficiency is the band gap of the semiconductor, because "the simplest semiconductor cannot absorb below band gap photons" (Tom, 2003). Some researchers attempt to achieve high efficiencies by coating multilayer materials on crystals, but this method results in complex problems such as strain damage to the crystals. Recently, fortunately, there seems to have been a breakthrough in higher efficiency photovoltaic cells. Scientists at the Ohio State Institute for Materials Research announced that they have created a new electrically conductive plastic which is able to absorb all spectrums of visible light. This new research into improving efficiency is extending photovoltaic systems' use and markets. 


\subsection{Evolution of photovoltaic building forms}

Photovoltaic building forms are also evolving. Similar to organisms' evolution, building forms develop from simplicity to complexity, from monotone to variety. One economic reason for this is that capital costs of photovoltaic material keep falling due to economy of scale. Meanwhile, conversion efficiency, affecting photovoltaic materials for use as building components, keeps increasing over time.

Some scientific facts explain why prototypes of photovoltaic buildings have been relatively simple in details. First, fragile photovoltaic materials such as silicon cells need transparent materials, usually highly transparent glass, with reliable hardness for support. Second, different angles of the photovoltaic material towards the sun will generate different voltages, which can result in the failure or bad performance of the photovoltaic system. In addition to this, products those are easy and cheaper to manufacture dominated architects design of photovoltaic buildings. These factors influenced the architects' early explorations of form-making. However, architects are now attempting to break through this barrier against architectural design, as shown in the projects discussed in the following sections.

\subsubsection{Form making towards efficiency and optimization}

Rather than being translated into buildings gracefully, photovoltaic technologies radically changed buildings' forms at an early stage of Building Integration of Photovoltaic systems (BIPV). In this early period, building forms were not made particularly for this technology. On the one hand, the low efficiencies of photovoltaic technology required a relatively large surface area on buildings, which usually for other building components. On the other hand, the high cost forced architects to consider technical function first. As a result, prototypes of photovoltaic integrated buildings were designed in a more engineering way. To maximize energy generation from these expensive but low efficiency materials, architects had to sacrifice most of the roof areas, tilting them into optimizing angles. So the building space had to become the secondary consideration in a photovoltaic building. As a result, these prototypes were not attractive to ordinary people. This posed the question of functional conflict (see Figure 4).

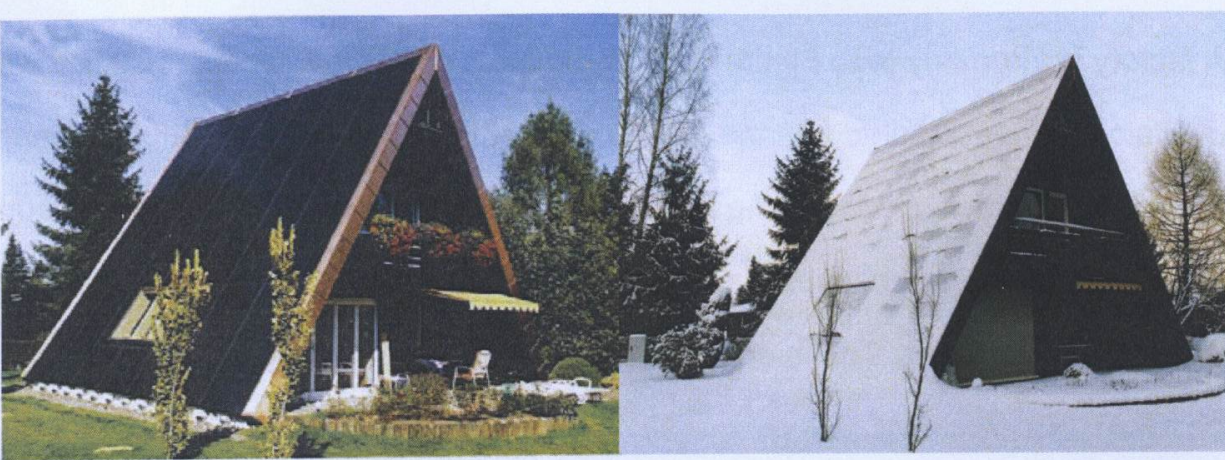

Figure 4. A vacation house in Ferienhaus Bartholoma-Park, the roof is a completely integrated photovoltaic system.

Because of functional and material limitations, a single mono-pitched roof doesn't satisfy as an architectural composition to arrange space and building materials. Besides, size, shape, and aesthetic quality will direct an architect to find other means to deal with photovoltaic panels. In this situation, multi-louver techniques as visual or semi-visual elements can be considered. This strategy is suitable for individual multi-storey buildings, such as hospitals, hotels, museums, and city halls. The photovoltaic louver can be a major or minor component of a building. Balance and equilibrium can be achieved through delicate architectural composition. In this case, surface consciousness is raised when photovoltaic louvers are mounted on a building façade (see Figure 5).

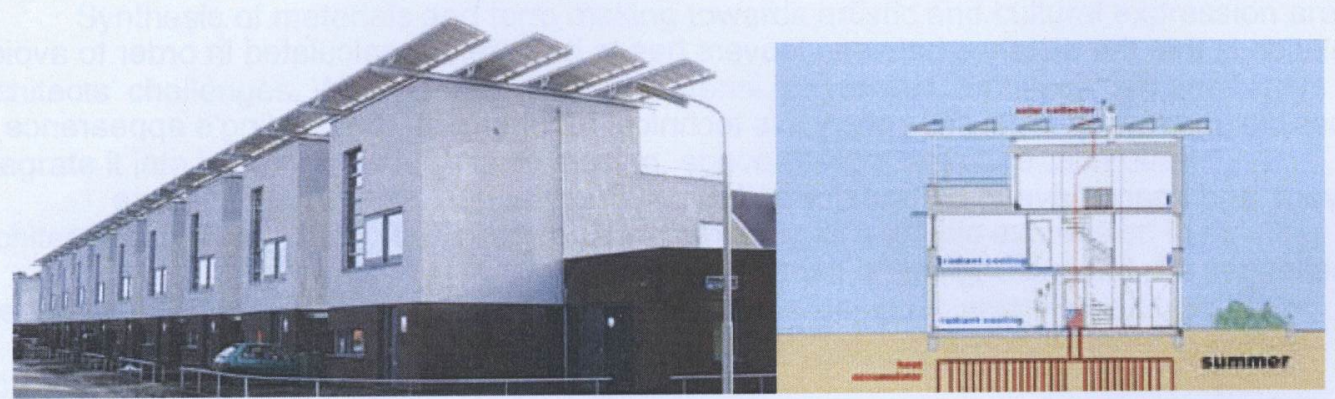

Figure 5. Down 2000 Zero emission houses with photovoltaic awnings on roofs. The space underneath the roof is not impacted by the photovoltaic installation. 
A factory in Germany (see Figure 6) is an example of a whole facade installed with photovoltaic awnings. Mounted on the façade are $575 \mathrm{~m}^{2}$ photovoltaic modules generating one fifth of the electricity needs of the factory; $210 \mathrm{~m}^{2}$ modules are in front of the south facing wall. The angle is assigned to optimize summer sun radiation, and to allow the winter sun to penetrate into the building. The interior space under the tilted facade is a circulation area.

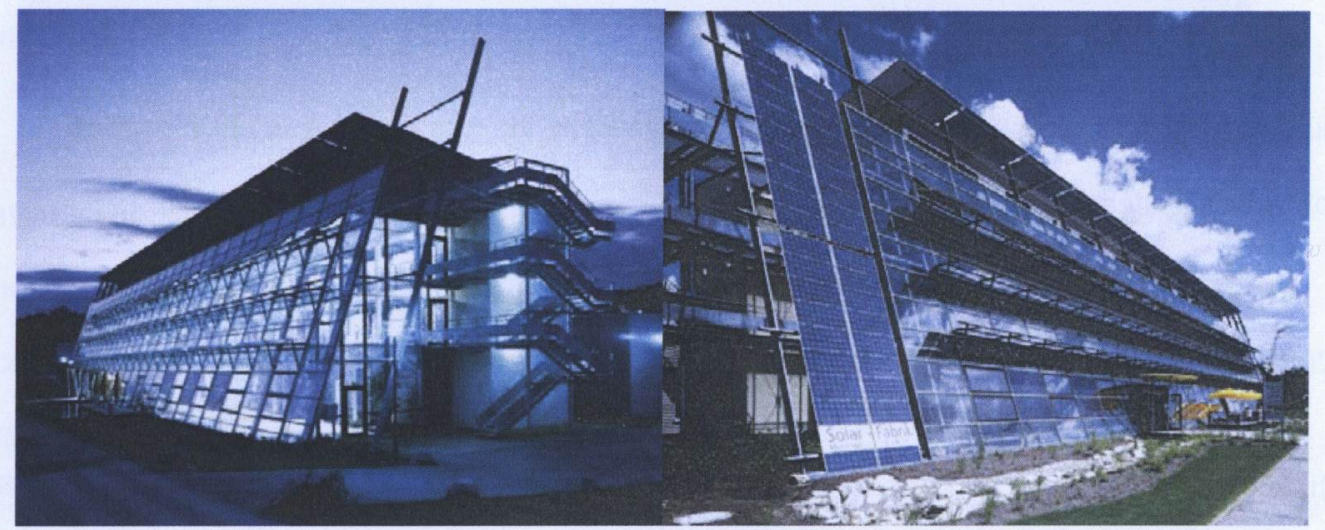

Figure 6. Solar Fabrik, Freiburg, Germany, the east view of this Europe's first zero- emissions solar module factory.

This example, based on engineering thinking, aims to maximize efficiency. Building forms can be lengthened to house more rooms or functional areas. By separating one roof into louvers, photovoltaic panels can harvest equal solar radiation. The drawback to this solution is that the distance between louvers has to be carefully calculated in order to avoid possible shadow on them. To satisfy this technical requirement, the building's appearance, layout, and space have to be transformed to suit the changes (see Figure7). These challenges are beyond engineers' capacity to solve.

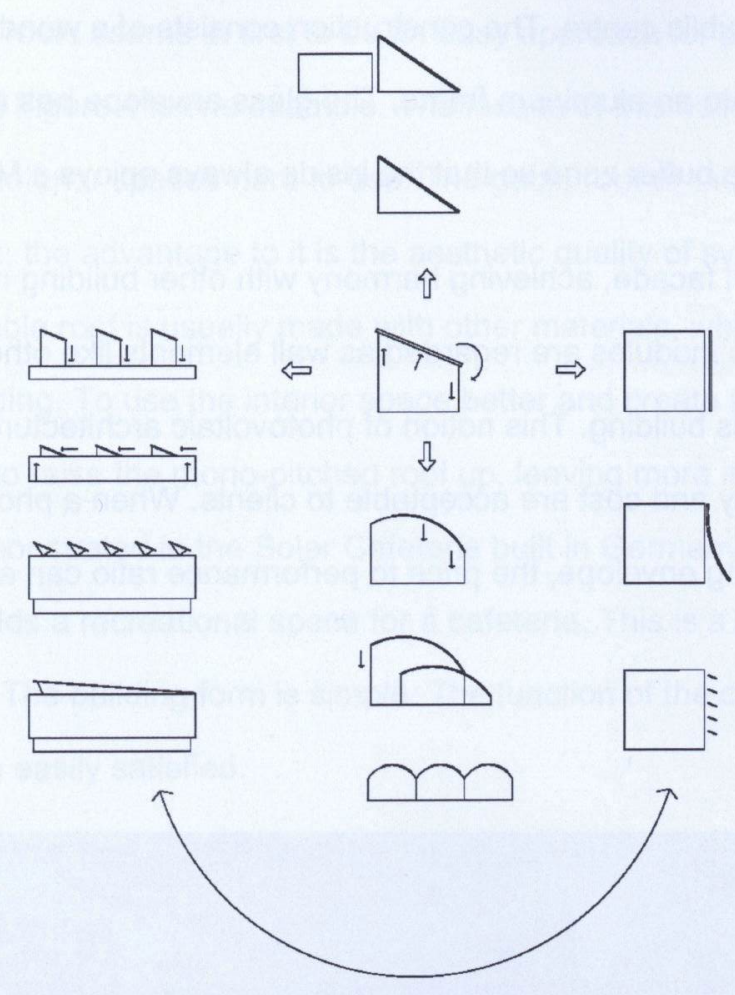

Figure 7. Transformation of building forms to satisfy technical requirements.

\subsubsection{Form making towards aesthetic and cultural expression}

Synthesis of materials and form making towards artistic and cultural expression are architects' challenges. When a new building material is invented, architects will seek ways to integrate it into buildings through form-making, space design, structure, and other architectural factors. During this process, the new material's artistic expression in building integration will be discovered gradually. This process of design is also happening with the architectural integration of photovoltaic materials

Photovoltaic materials can be integrated into various building forms. First, cubic thinking is a given for most architects. Mont-Cenis Academy is an example (see Figure 8). This public institution consists of many different functions: college, library, office, hotel, restaurant, 
recreation, sport and public centre. The construction consists of a wooden frame covered by glass that is inserted into an aluminum frame. The glass envelope has an area of $20.000 \mathrm{~m}^{2}$ and produces a climatic buffer zone so that the inside always enjoys a Mediterranean climate.

Another successful facade, achieving harmony with other building materials, is shown in Figure 35. Photovoltaic modules are regarded as wall elements like other wood panels, creating harmony in this building. This notion of photovoltaic architecture can become possible if the efficiency and cost are acceptable to clients. When a photovoltaic system is integrated into a building envelope, the price to performance ratio can also be reasonable (Dehra, 2004).

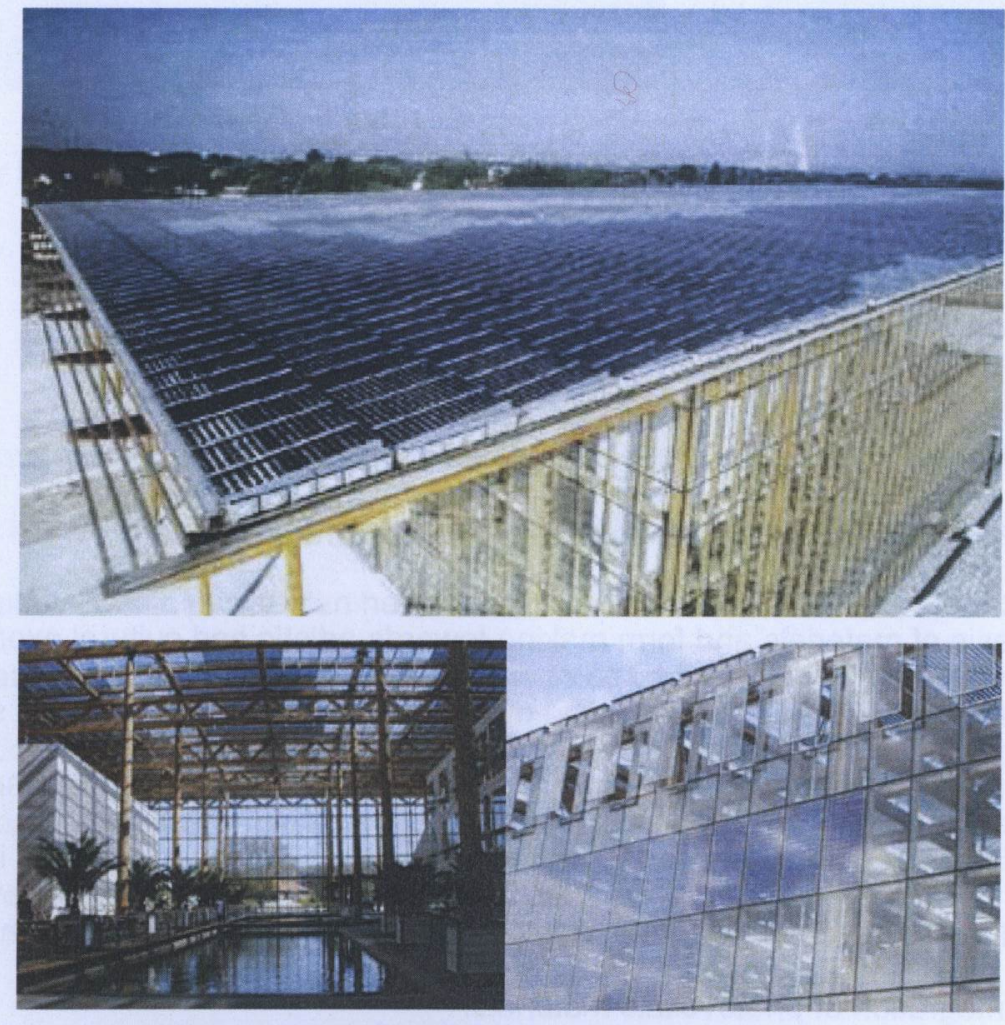

Figure 8. Mont-Cenis-Academy in Herne Sodingen, Germany, Germany,From International Energy Agency( IEA ) Photovoltaic Power Systems Programme.
Using pitched roofs seems at first to be an easy approach for photovoltaic integration. The summer house in Figure 4 is one example. The facade of this building is completely tilted but this leaves many interior spaces hard to use. The gable roof or facade is a traditional notion for an architect; the advantage to it is the aesthetic quality of symmetry. However, the shaded side of the gable roof is usually made with other materials, which gives a sense of imbalance to the building. To use the interior space better and create an independent effect, another technique is to raise the mono-pitched roof up, leaving more interior spaces for use. This technique is demonstrated in the Solar Cafeteria built in Germany (see Figure 9). Its mono-pitched roof holds a recreational space for a cafeteria. This is a prototype of a typical photovoltaic building. The building form is simple. The function of the cafe, demanding little of space or form, can be easily satisfied.

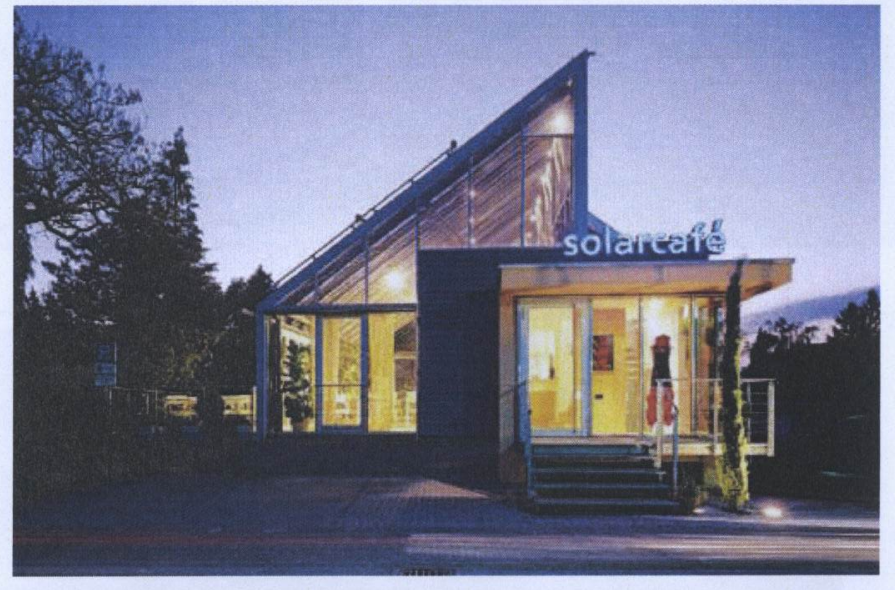

Figure 9. Solarcafé "Sonnenzeit" in Kirchzarten,Germany.

What if the space need is changed or the area needs to be increased? Can this simple form be used in this situation? Canoga Park Branch Library in Los Angeles provides a good solution. (see Figure 10). This library's space needs are more complex than those of small residential and service buildings. To house the major function areas, the architects designed a tilted roof supported by a steel grid system. The lecture room, separated from the major reading area, is a massive cylinder. This one storey building does not show the conflict between space arrangement and roof forms. 


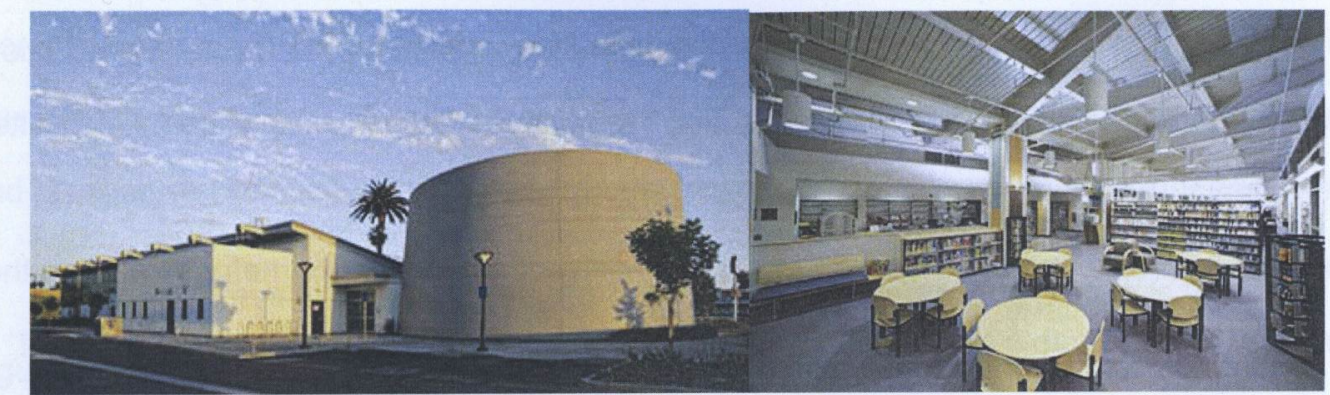

Figure 10. Canoga Park Branch Library in Los Angles.

Can mono-pitched photovoltaic roofs be used in multifamily buildings and communities? A possible approach to relieving the dull sense that mono-pitched roofs bring is to employ the principle of rhythm, for instance, designing even multi-unit communities in which the tilted roofs can be arranged in rows. In the case of the Solarsiedlung project (see Figure 11), maximizing solar gain was the primary goal, but by separating solar roofs into several similar forms in the principle of rhythm, architect Rolf Disch also created a successful harmony.
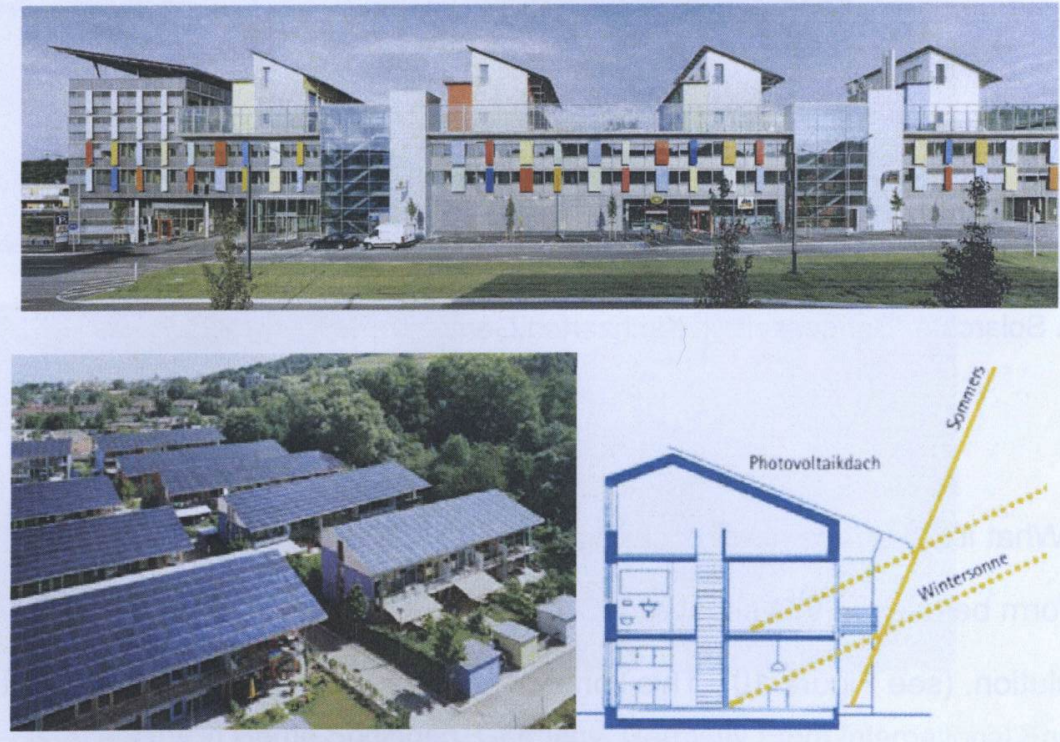

Figure 11. Solarsiedlung in German, designed by Rolf Disch.
One of the aesthetic challenges for a single-pitched roof is the monotony of a large area of deep blue photovoltaic panels. To solve this problem, some tectonic techniques are applicable. For instance, a single photovoltaic roof can be transformed into saw tooth roofs By doing this, the architect has extended the whole span north-south, providing opportunities for housing many functional areas. Interior space can be flexible due to the structural system. The side curtain wall offers great daylight (see Figure 12).

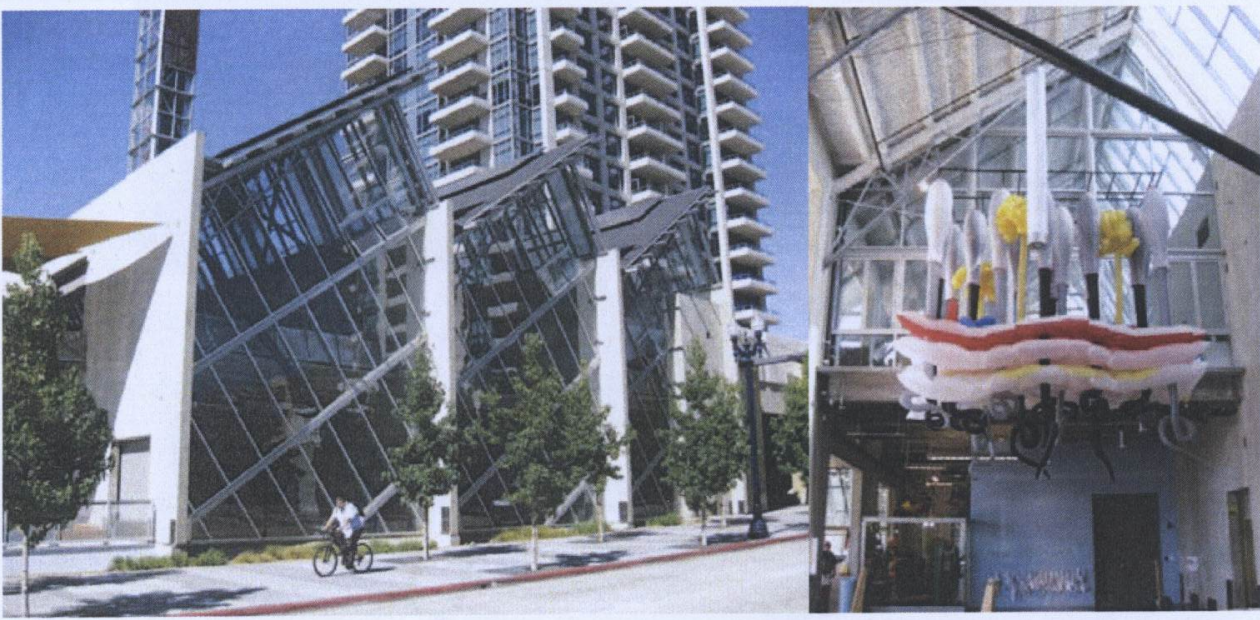

Figure 12. San Diego Children's Museum, photos showing multiple pitched roofs integrated with photovoltaic and interior space.

Saw tooth roofs can also be integrated into other irregular forms, such as oval shapes. The office building of Flora Exhibition International in Shenzhen China (see Figure 13 ) is oval shaped with a photovoltaic roof. This is an example of how creative design of multiply pitched roofs becomes possible. However, a new problem presented by this building is that the oval shape cannot satisfy both optimum solar radiation and other architectural issues such as interior space and natural ventilation. In this case, the long axis of oval is useful for arranging photovoltaic panels, but not for conducting the south east wind in the summer 

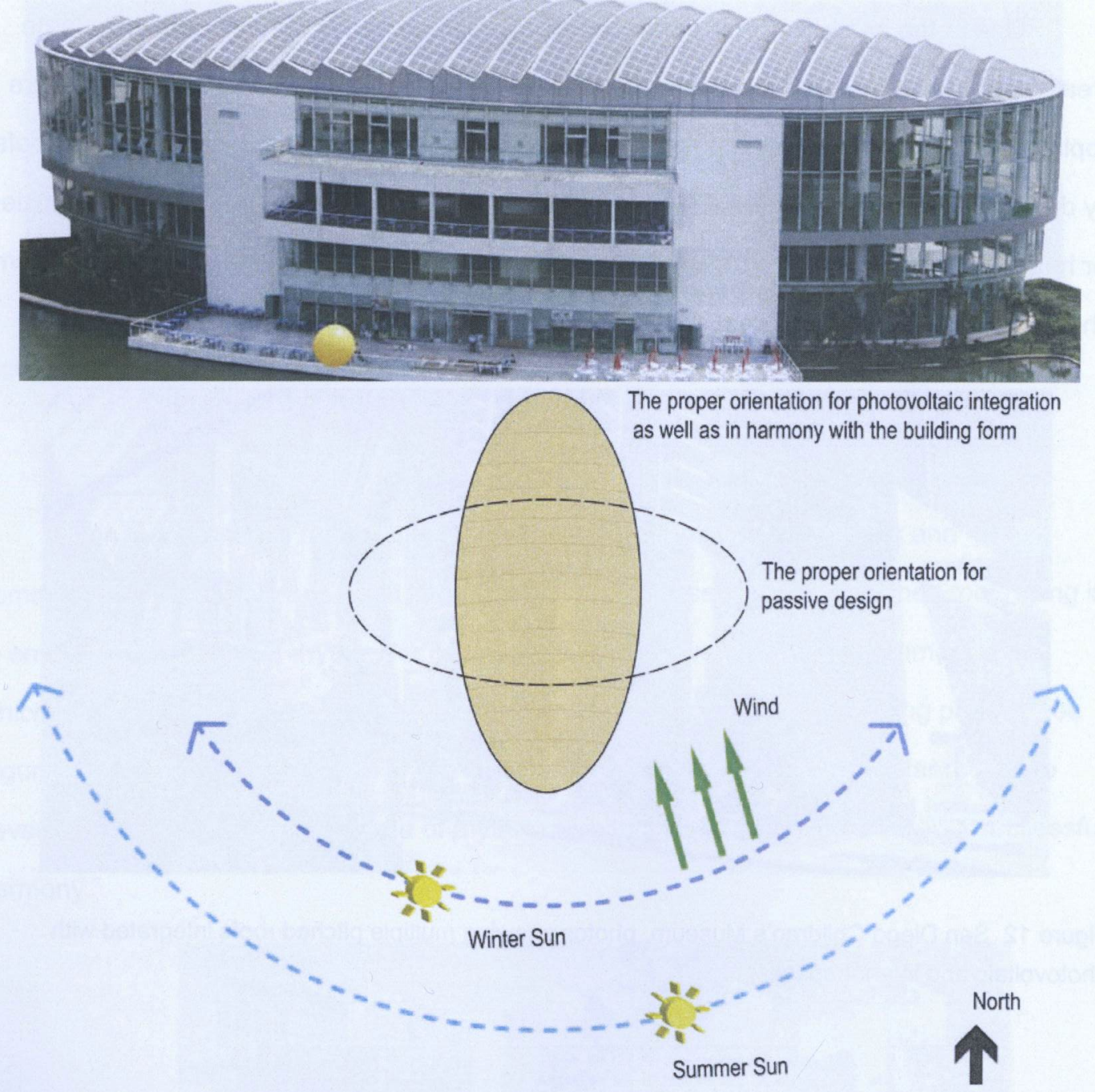

Figure 13. ShenZhen Floral Exhibition 2007 office building, perspective showing saw tooth roof integrated with oval shaped building form. The diagram below illustrates the controversy of optimum orientation for passive solar design and active solar design.

The office building of Flora Exhibition International is also an example of integrating photovoltaic materials into one of cylindrical building. Another similar application is Tobias Grau KG Office, near Hamburg, Germany (see Figure 14). These two squeezed "tubes," connected by a two storey office space, have photovoltaic modules mounted on their south facade. From an architectural perspective, these thin film photovoltaic modules provide different optical effects over time. They are deep blue in the daytime, preventing the sun from overheating the interior. At night, the semi-transparent photovoltaic modules function like a silk screen, providing certain privacy for the interior workshops. From a technical point of view, this vertical surface is less efficient than a horizontal one. In the Hamburg region, the daily solar radiation on a vertical south surface is only $64 \%$ of that on a horizontal surface based on my calculation using RETScreen Version 4 Beta.
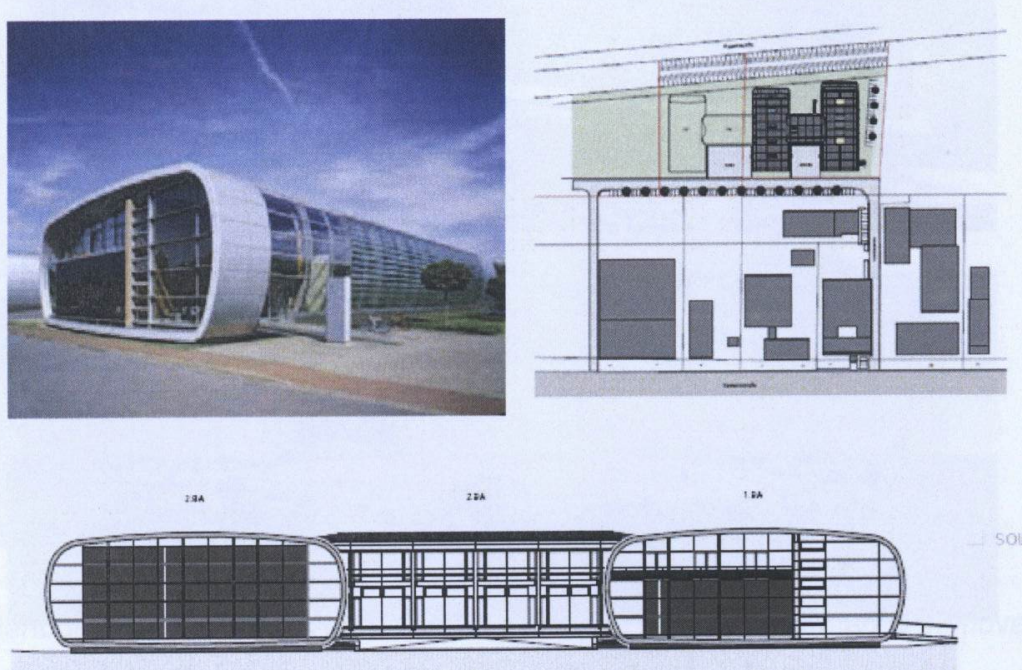

Figure 14. Tobias Grau KG Office, designed by BRT Architeckten.

In fact, cylindrical forms can provide higher energy efficiency than the Tobias Grau KG office building if their curved surfaces are carefully orientated. In the example of Coney Island's Stillwell Avenue Terminal in New York, Kiss + Cathcart, Architects demonstrated this possibility (see Figure 15). They designed a slightly curved photovoltaic canopy for the subway station. This photovoltaic canopy can reach up to $88 \%$ of a horizontal envelope in the same locality based on my calculation using RETScreen Version 4 Beta. This semi-transparent structure, reminding people of an image of bird's wing, is also expressive even at night. 

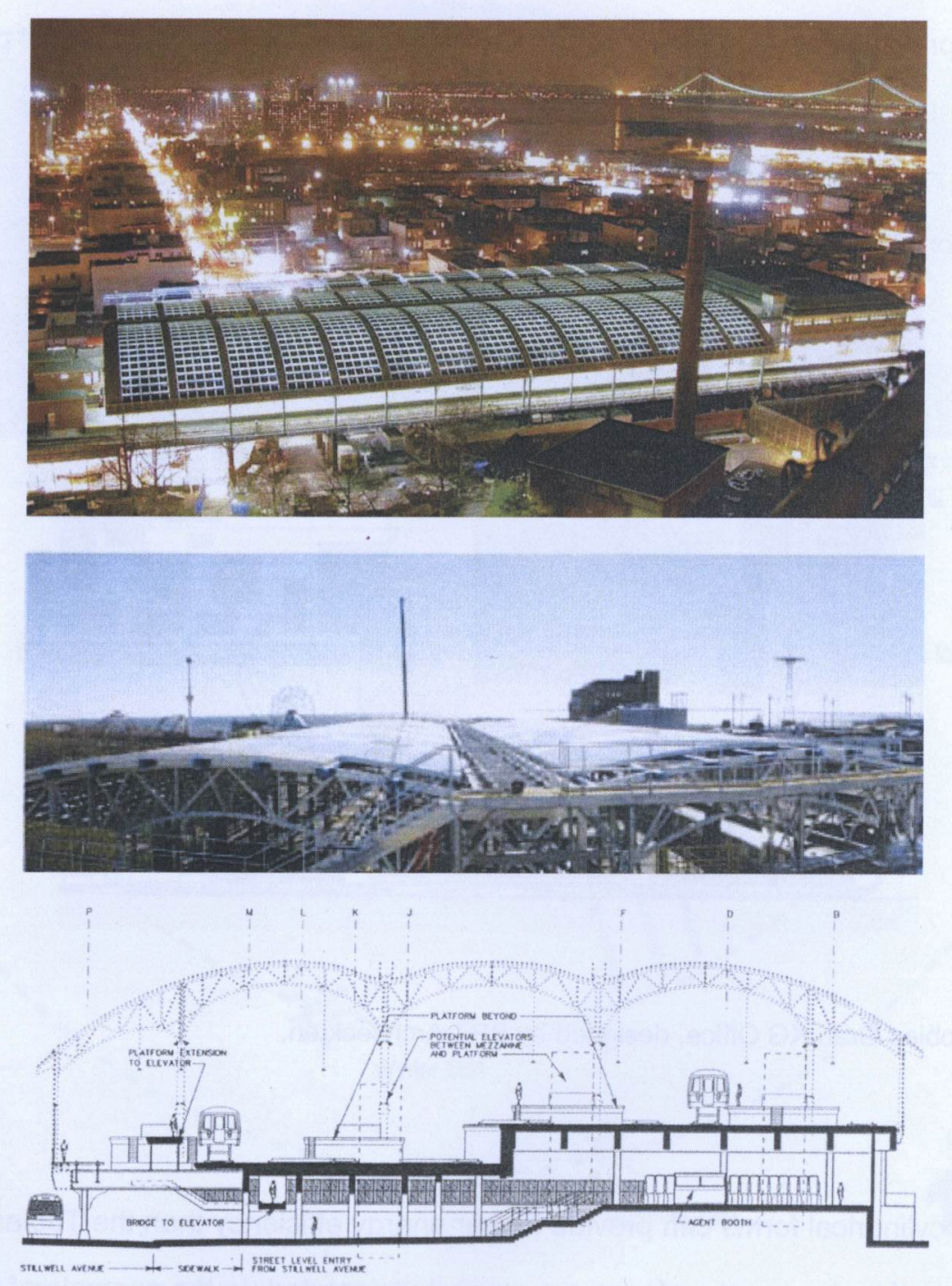

Figure 15. Coney Island's Stillwell Avenue Terminal in New York, designed by Kiss + Cathcart Architects.

These two examples illustrate how to integrate photovoltaic materials into cylindrical forms statically. One example of integrating a photovoltaic wall dynamically into a cylindrical form is Oldenburg Stadium EWE-Arena (see Figure 16). Architects Arat Siegel Schust integrated a movable grey photovoltaic wall $6.5 \mathrm{~m}$ in height and $40 \mathrm{~m}$ in length, providing shade and solar gain for this building. The 18 separate segments contain 72 separate grey monocrystalline PV panels laminated into toughened-laminate glazing panels and connected in modules. The 72 monocrystalline photovoltaic panels can generate $14.76 \mathrm{kWp}$ for the stadium. Every half hour the moveable photovoltaic panels can rotate 7.5 degrees along a 160 metre track like a sunflower (Colt Group, 2008)

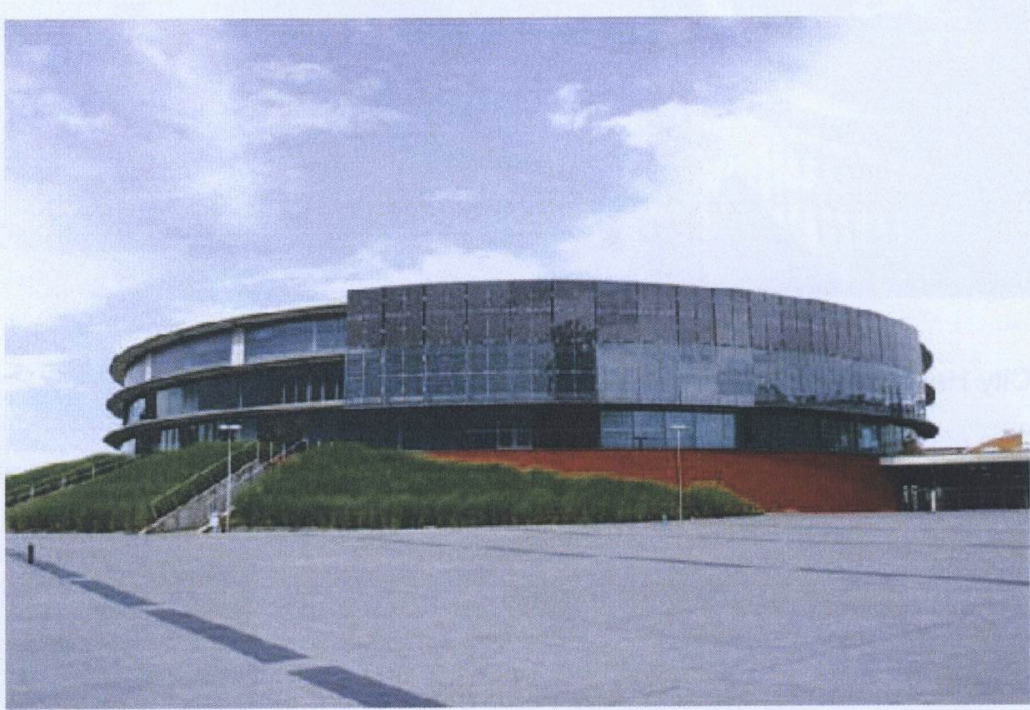

Figure 16. Oldenburg stadium EWE-Arena, cylinder shaped facade integrated with movable photovoltaic panels.

One aspect that clients and architects for the Oldenburg stadium had to consider is the conflict between constant electricity generation and dynamic energy use in stadium buildings. However, this would not be a problem in a country where the government promotes green energy subsidies.

One extreme case is to integrate photovoltaic materials into ovoid form. Foster + Partners, Architects, designed an additional photovoltaic roof for the London City Hall, making it egg-shaped (see Figure 17). The geometric profile of photovoltaic modules is perfectly in harmony with this ovoid form. However efficiency is not optimized due to the roof's orientation, nor are the slope angles optimized. In addition, the public have argued that the expensive photovoltaic system, $f 540,000$, is not worth its $1.5 \%$ saving on conventional energy (London SE1 website team, 2008). 


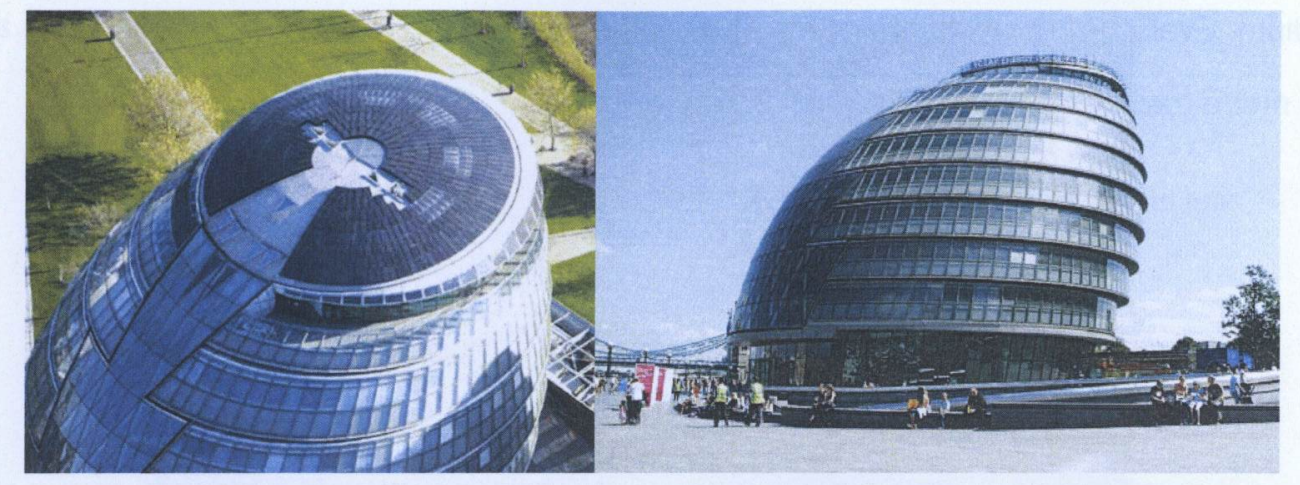

Figure 17. London City Hall, roof integrated with photovoltaic panels. Designed by Foster + Partners.

\subsubsection{Three approaches to creative design}

From the discussion above, the diversity in architectural thinking also can be defined as taking three directions: the fixed azimuth angles system, the tracing system, and mixed azimuth angles. Turbulence house is one example of fixed azimuth angles for a photovoltaic system integrated with roofs. Heliotrop is a typical tracing system integrated with roofs; and Steinhude Sea Recreation Facility is a good example of mixed azimuth angles for a photovoltaic system integrated with roofs. (see Figure 18)

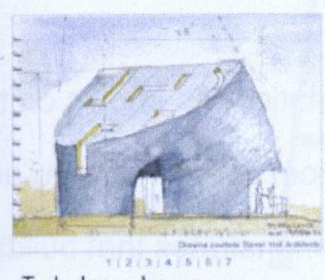

Turbulence house

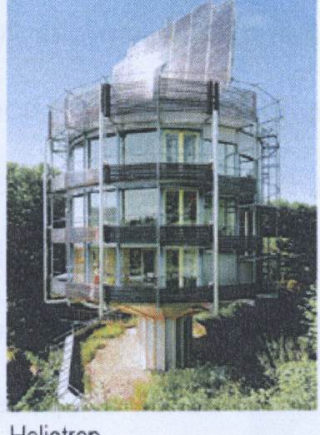

Heliotrop

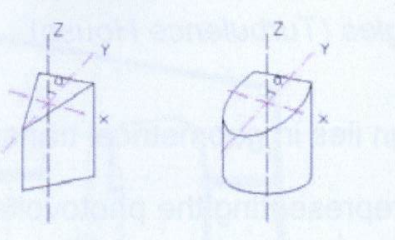
$<$ Given a fixed slope and an azimuth angle, both the periphery of photovoltaic roof can be modified and building forms can vary in space
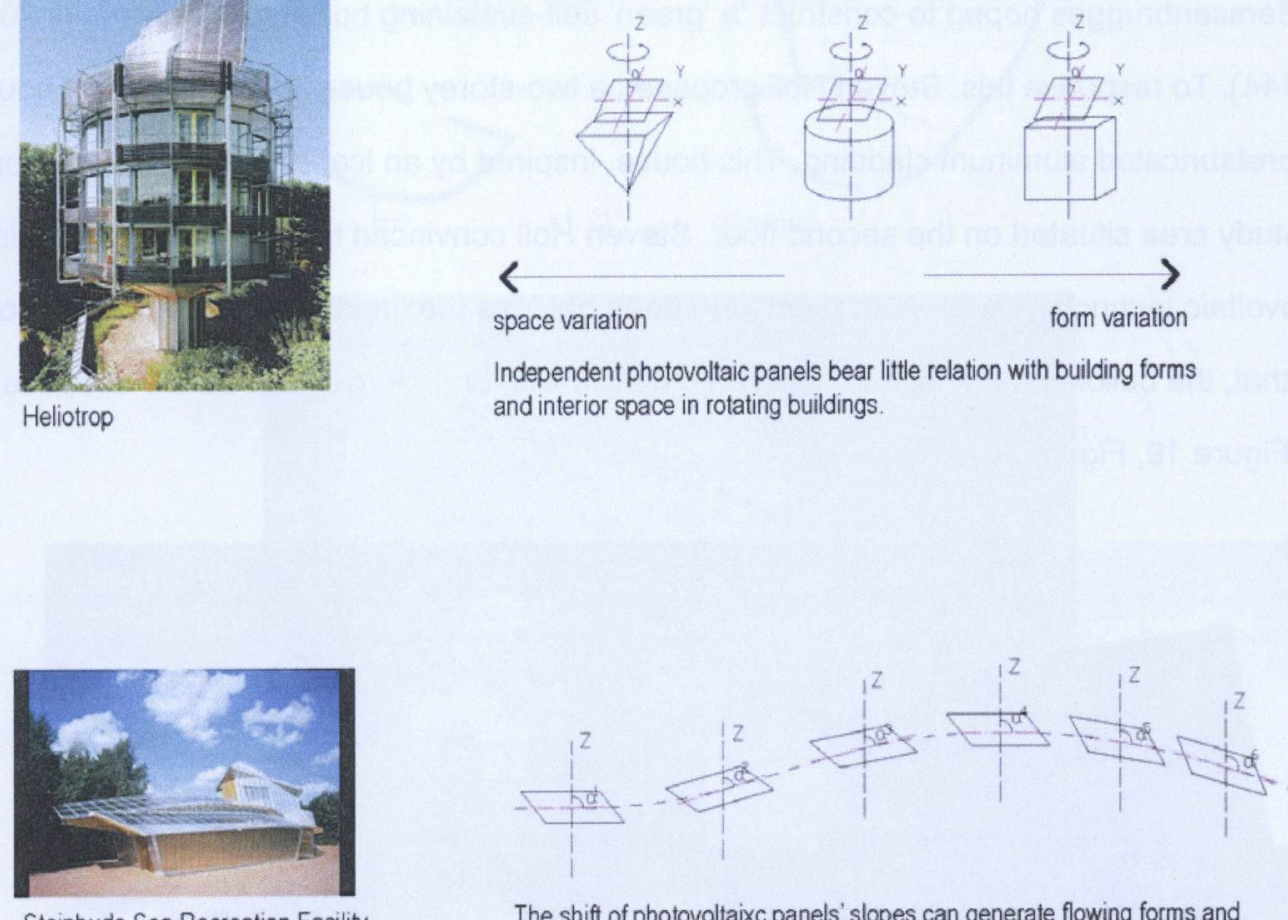

The shift of photovoltaixc panels' slopes can generate flowing forms and dynamic interior space

Figure 18. Three approaches to form-making in building integration of photovoltaic materials. 


\section{Approach one: Fixed angles (Turbulence House)}

An opportunity for creative design lies in geometrical transformation. As shown on the top diagram of Figure 18, an XY plane representing the photovoltaic roof can conform to any shape and form underneath without altering the slope angles. This demonstrates that building forms, roof perimeters, and space can be complex.

Turbulence House, designed by Steven Holl's studio for an artist couple Richard Tuttle and Mei-Mei Berssenbrugge, is an example of the approach to photovoltaic integration. The Berssenbrugges hoped to construct "a 'green' self-sustaining building," (Giovannini,2003, 138-144). To response this, Steven Holl proposed a two-storey house, 900 square foot house with prefabricated aluminum cladding. This house, inspired by an iceberg, has a guest room and study area situated on the second floor. Steven Holl convinced his client that integrating photovoltaic technology with an organic form need not lose the function of the building; more than that, the building he designed generated a style with an unforgettable sense of space (see Figure 19, Figure 20)

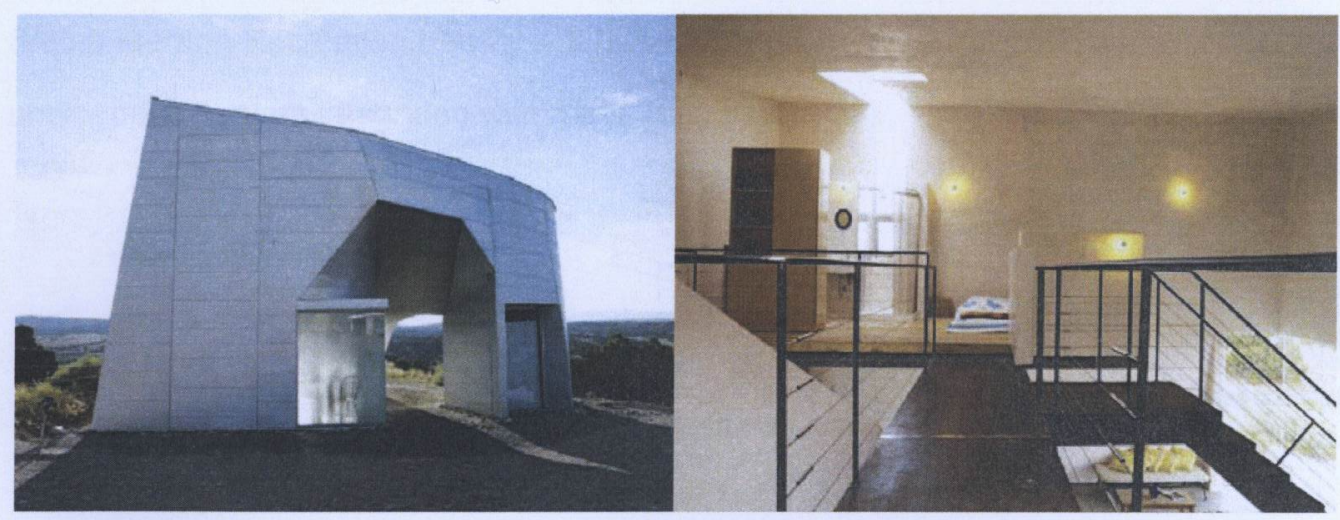

Figure 19. Turbulence house, designed by Steven Holl. The tilted roof is mounted with photovoltaic panels to optimize solar gain. The second floor houses a bedroom and a study area.
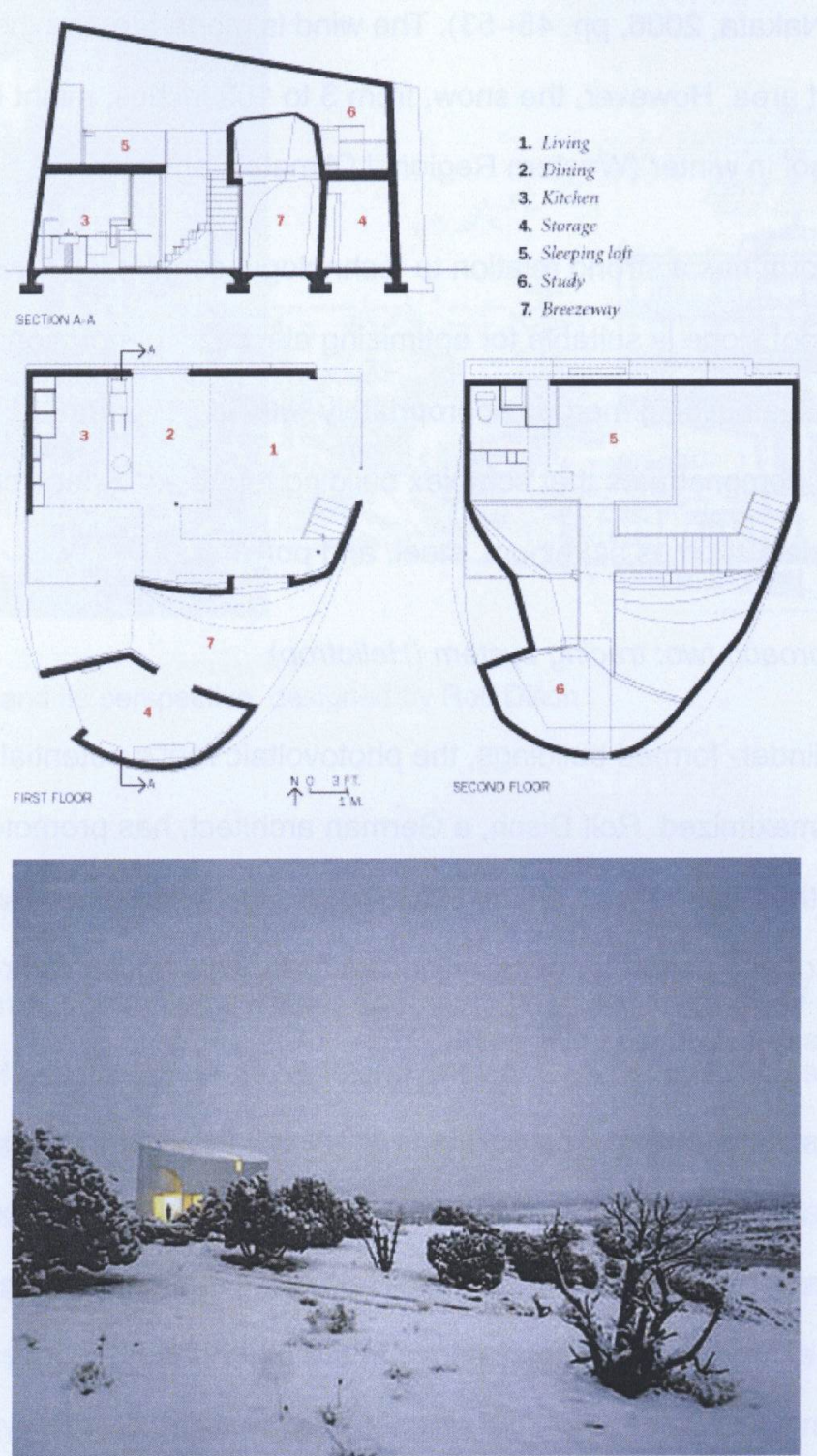

Figure 20. The tilted roof of Turbulence House covered by thin snow.

There are long hours of solar radiation annually in New Mexico where this house situates. "The average number of hours of annual sunshine ranges from near 3,700 in the southwest to 2,800 in the north-central portions " (Western Regional Climate Center, 2008, p.1). Due to this, the initial photovoltaic roof panels can generate enough electricity to power the whole guest house. Additional PV panels can produce up to $3.3 \mathrm{kw}$-hr/ day for this couple's own adobe house that not far from this house. The radiant floor heating system is also powered by 
the roof PV cells (Nakata, 2006, pp. 45--53). The wind is moderate and there is little precipitation in that area. However, the snow, from 3 to 100 inches, might be a problem for this photovoltaic roof in winter (Western Regional Climate Center, 2008).

This building form has a strong relation to technology, context, and the architect's intent. For instance, the roof slope is suitable for optimizing electricity generation. The desire to produce a sustainable building merges appropriately with its geographical context. In addition, Turbulence House demonstrates that complex building forms and space can be realized by using elastic materials such as aluminum, steel, and polymer

\section{Approach two: tracing system (Heliotrop)}

By rotating cylinder- formed buildings, the photovoltaic roof's potential for energy generation will be maximized. Rolf Disch, a German architect, has promoted the idea of rotating houses with Heliotrop (see Figure 21). Photovoltaic and thermal collectors are mounted on the roof and perimeter of its cylindrical form. This house can rotate along its central vertical axis to maximize solar gain

This idea is inspiring, but rotating buildings challenge the balance between energy consumption and energy generation. One aspect for concern is that the extra electricity gained through this approach is only about $10 \%$ in a two direction tracking system and less than $20 \%$ in a three direction tracking system. On the other hand, the investment in the mechanical system could be several times higher than the extra electricity gained from the tracking system. Another aspect for concern is that these revolving buildings are not suitable for large scale building for mechanical reasons. The larger a building is, the more energy and the larger mechanism for rotating the building will be needed.

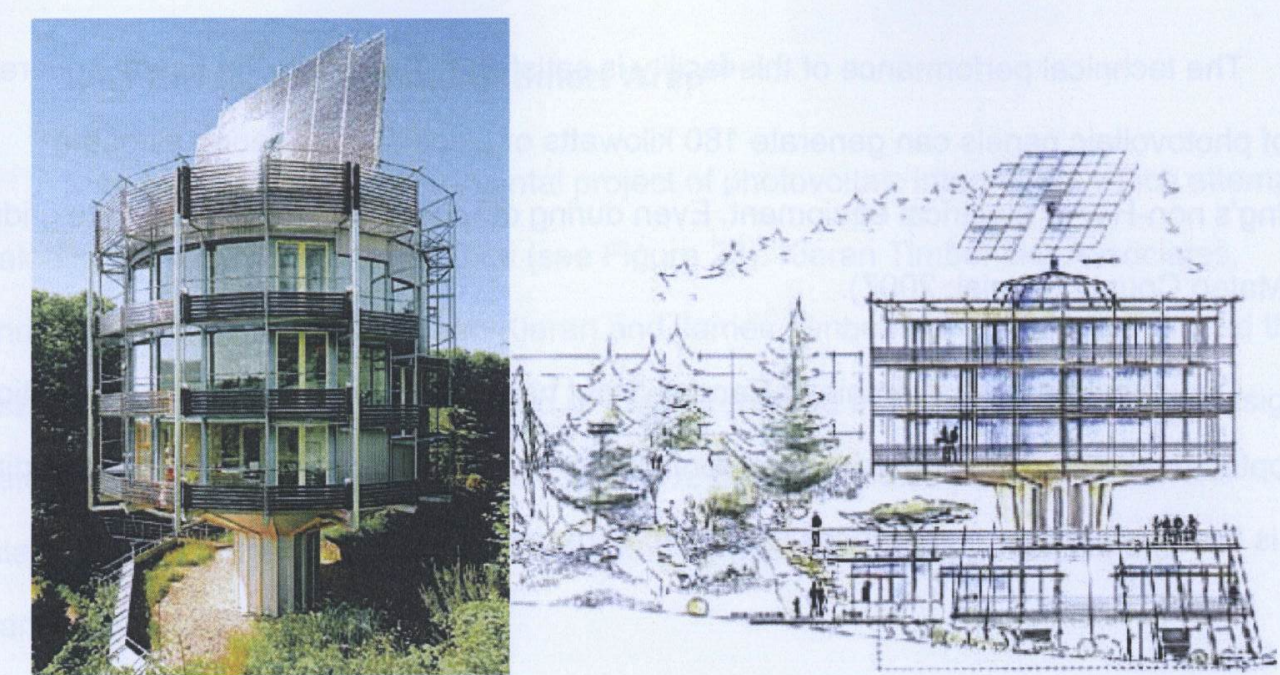

Figure 21. Heliotrop and its perspective, designed by Rolf Disch.

Approach three: flowing forms (Steinhude Sea Recreation Facility)

Flowing forms, containing surfaces with various angles, are one of the approaches to achieve this kind of satisfaction in architectural design. Geometrically, by shifting the XY plane to another spatial position with a changing slope angle, architects can generate flowing forms for photovoltaic roofs. Flowing forms both attract and challenge. On the one hand, pleasure can be achieved through imitating the proportion, structure, or space of natural things (Steadman, 2008); on the other hand, synthesizing flowing forms with photovoltaic panels needs solid technical knowledge and practices.

There have been many vigorous explorations of flowing forms since industrialization. Architect Randall Stout brought this idea to photovoltaic technology. In the small Steinhude Sea Recreation Facility in Germany, he challenged the nature of photovoltaic cells against the nature of contemporary architecture (see Figure 22). This building's flowing form, derived from his schematic idea of eels, could provide opportunities for creative architectural design with photovoltaic technologies. 
The technical performance of this facility is satisfying. Twenty-six thousand square feet of photovoltaic panels can generate 180 kilowatts of electricity, powering all of the building's non-HVAC electrical equipment. Even during off-peak hours it can export to grids in San Mateo County (Daniel, 2007).

One of problems that Architect Randall Stout had to face lay in building's orientation. The optimum orientation for interior view conflicts with photovoltaic needs. The final building form is the result of how he balances these two demands.

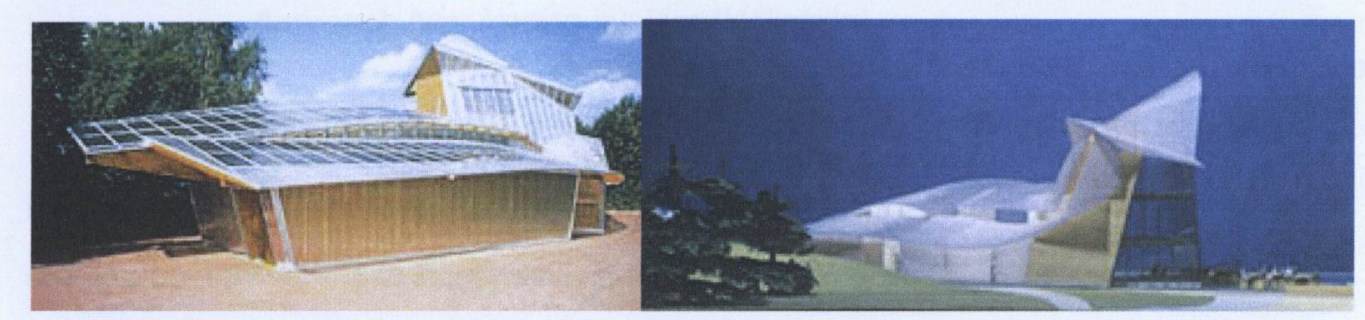

Figure 22. Steinhude Sea Recreation Facility.

\subsection{Aesthetic and cultural expression in photovoltaic buildings}

Any new material experiences a long process of being adapted into buildings and structures. Plastic, for example, has been adopted into buildings for decades. In the early stages of using plaster or plastic in buildings, these flexible materials were used mostly for temporary building components such as side walls. However, contemporary architects have been exploring other design opportunities in architectural integration of plastic. What they have done proves that plastic forms, from folded-plate to dome structures, from shells to membranes, can produce sensual and provocative effects, expressing artistic and cultural meanings (Jeska, 2007)

Photovoltaic materials are also experiencing the similar pattern of development. In some experimental architectural studies, major aspects of photovoltaic materials as building materials are being explored. Smart Wrap ${ }^{\mathrm{TM}}$ is one of these examples.

\subsubsection{Envelop of the future: Smart Wrap ${ }^{\mathrm{TM}}$}

Smart Wrap ${ }^{\mathrm{TM}}$ is an experimental project of photovoltaic integration, which attempts to break a rigid image in people's minds (see Figure 23). Kieran Timberlake Associates, founded in Philadelphia by Stephen Kieran and James Timberlake in 1984, conducted this research. Their initial idea was to get rid of the stereotyped thought of photovoltaic design, to create a new colourful, impressive, demonstrative photovoltaic structure. There were obstacles that the architects had to face when they integrated their notions in the SmartWrap ${ }^{\mathrm{TM}}$ project.

1. Weather-proof

2. Manufacturing time and material costs

3. Occupied or non-occupied buildings

4. Conflict of transparent photovoltaic layer and other opaque layers of building components

To achieve their objectives, Kieran and Timberlake treated elastic photovoltaic materials as a transparent wall which can be printed, rolled, and installed. They chose a clear film material called polyethylene terephthalate (P.E.T), a cheap, colourless polymer with low moisture absorption. The whole building skin consists of this material, laminated with other compositions such as "organic light emitting diodes (O.L.E.D.s), organic photovoltaic materials (O.P.V.s), phase change materials (PCMs), thin film batteries, and printed circuitry" (Tanzer, 2007, p. 224)

The power generated by thin film photovoltaic materials is stored in thin film batteries embedded in the same building skin. Kieran and Timberlake used aerogel, a transparent material, for insulation. Aerogel is fragile and needs to be kept within certain thicknesses to achieve its insulating function. The dilemma that Kieran and Timberlake faced was satisfying insulating needs by adding a supplemental layer when this could reduce the building envelope's transparency. To enhance the transparent effects, they finally sacrificed the 
weather-proofing function of SmartWrap ${ }^{\mathrm{TM}}$.

Kieran and Timberlake claim that "SmartWrap ${ }^{\mathrm{TM}}$ is the building envelope of the future: a composite that integrates the currently segregated functions of a conventional wall and combines them into one advanced composite" (KieranTimberlake, 2008). The structural system is relatively simple. The whole structure of this pavilion is supported by aluminum frames. All the frames were premade and labelled before being delivered to the construction site.

Both its elaborate details and transparent appearance impress people. The light and its self-sufficient function stimulate the public's interest in sustainable design and creativity in sustainable design. On this limited level, it is successful. However, from an engineer's perspective, it is not. Vertical installation weakens the potential energy generation of the photovoltaic materials. Different slopes and azimuth angles of photovoltaic cells make other parts of photovoltaic system (for instance, inverters) more complicated and increase the system cost and possibility of system breakdown. This experimental project questions photovoltaic integration: how best to appropriately balance the rigid technical requirements of photovoltaic materials and aesthetic quality?

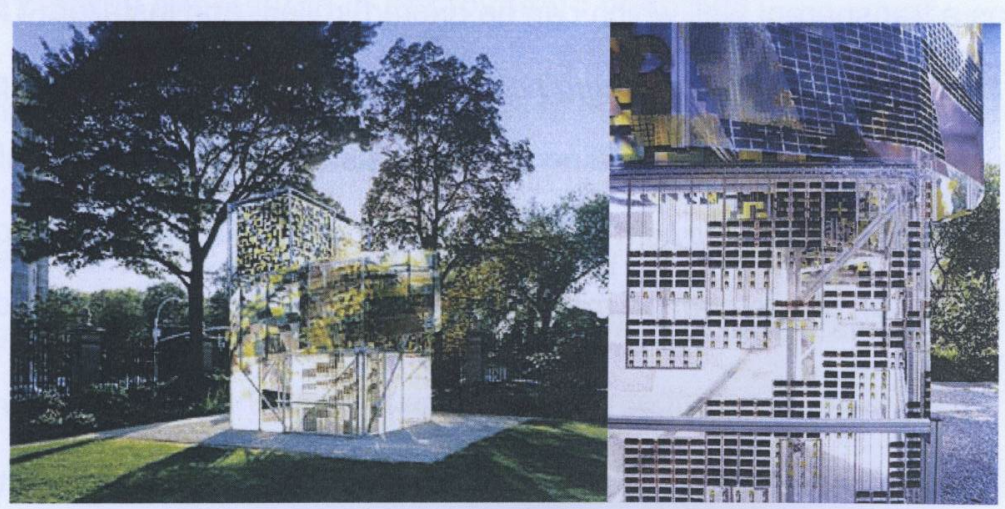

Figure 23. Exterior views of SmartWrap ${ }^{T M}$.

\subsubsection{Zero Energy Media ( The Green Pix)}

Smart Wrap ${ }^{\mathrm{TM}}$ provides an imaginative idea for photovoltaic building and structure. Zero Energy Media (The Green Pix), a self-sufficient LED display designed by Simone Giostra \& Partners and ARUP, push this idea forward. The fundamental motif is that the LEDs, controlled by an intelligent computer system, perform as a spectacular media screen at night. The whole wall can respond to data put into the computer, creating a variable building "skin". Solar cells are embedded randomly, creating an impressive effect in daytime. Simone Giostra \& Partners and ARUP also built a website to illustrate how the Green Pix functions. Figure 28 shows the different architectural effects of this entertainment building in the daytime and at night. The image on the bottom is the interface of the software they built for the Green Pix.

This algorithmic theme in architecture can be found in fine art. A computer-based cycle of art entitled "Agglomeration" by Vlatko Ceric, a Professor of Computing at the University of Zagreb, uses a similar concept. One or two simple mathematical elements are arranged randomly through a computer program to render complex and startling images (see Figure 25, Figure 26). Like the photovoltaic hotel, Vlatko Ceric's algometric works use a similar simplicity-to-complexity approach that takes one simple shape element to create a complex image in one given area. In Beijing's Rejing Hotel, architects use this approach to demonstrate that rectangular photovoltaic cells can be organized to create an attractive building facade (see Figure 24). The Green Pix raises a question: can architects integrate photovoltaic materials with their ideas in social and cultural dimensions? 


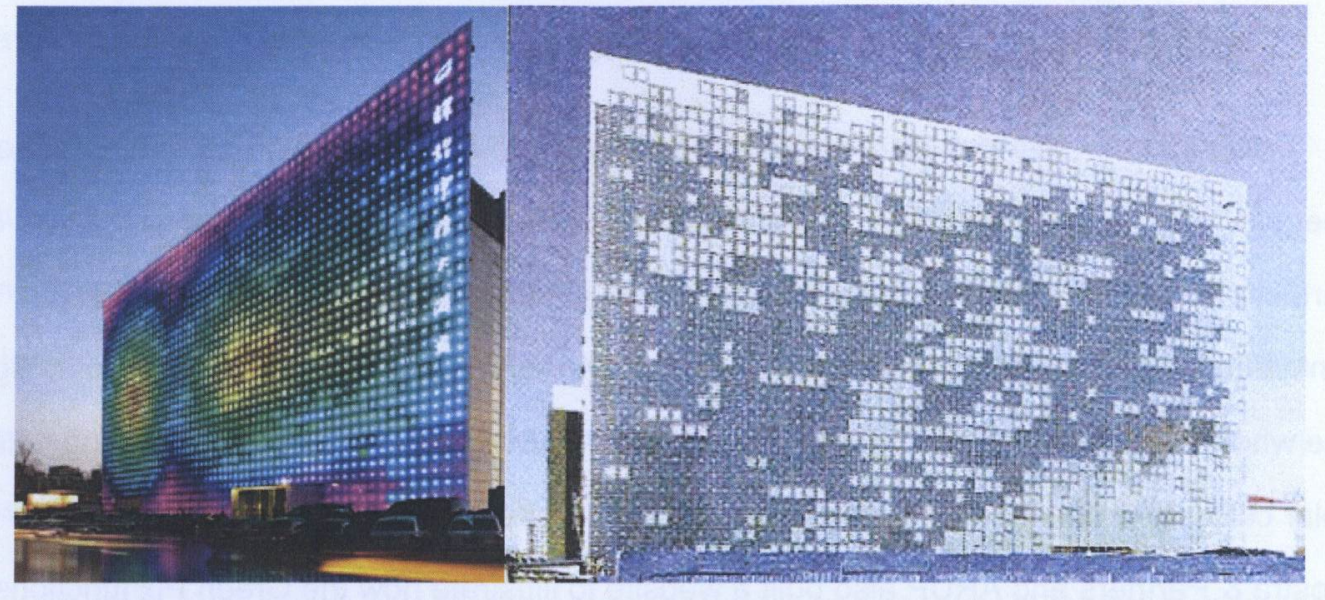

Figure 24. The Greenpix, facade integrated with photovoltaic cells and LED lighting system.

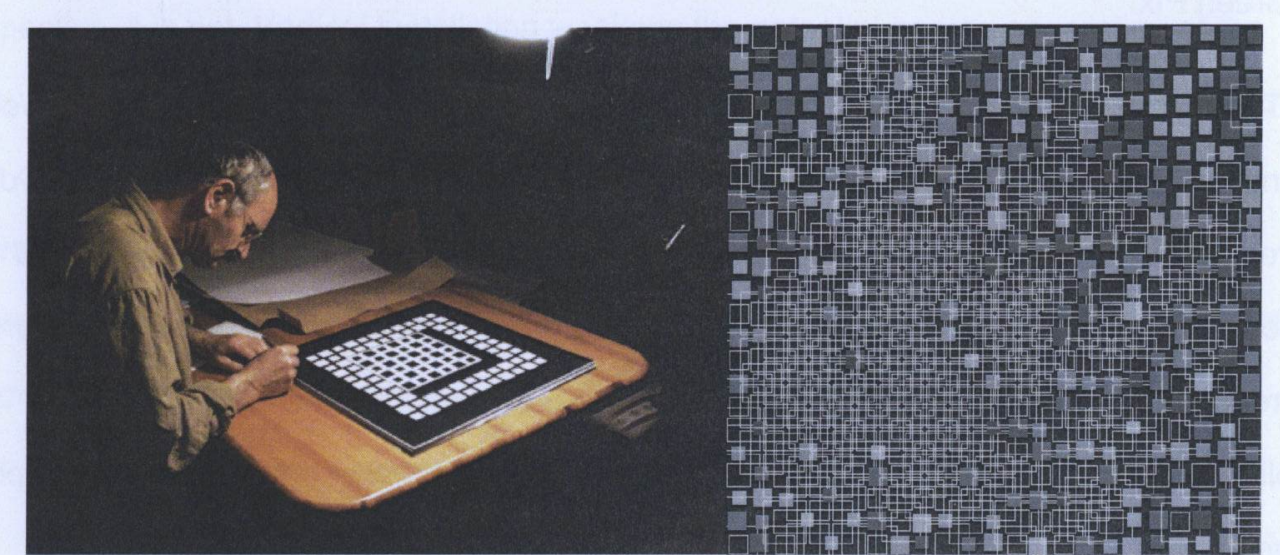

Figure 25. Vlatko Ceric is working on his art(left), the algometric works entitled "Agglomeration" by Vlatko Ceric (right)

$$
\underset{\text { single cell }}{\rightarrow \rightarrow} \underset{\text { Photovotalic matrix }}{\rightarrow}
$$

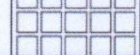

뭄ำ

Matrixes with different transpar-
ency, embedded in glass panels

.

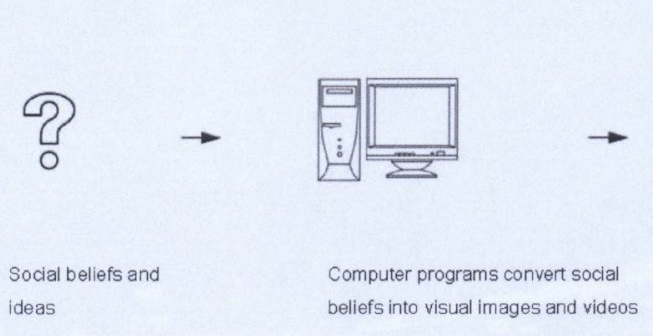

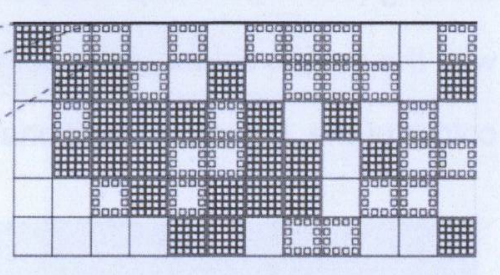

potovotaic panels, generatang electridty for a LED light ng system, create visual phenomenon in the dayxime

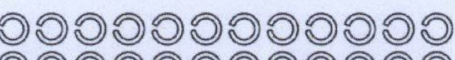

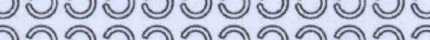
(2) 0 (2) 2002000

puter programs

Figure 26. A diagram illustrating how the Greenpix's photovoltaic facade is integrated LED lighting system. Drawn by the Author.

\subsection{Expression of Particular Cultures (The Japanese Sanyo Solar Ark)}

To express particular cultures, architects can turn to study connections among themes in this culture and society. For example, different accessories might be culturally linked to different levels of social status. The Sanyo Solar Ark is an example of such a way of expressing the rich Japanese culture and spirit (see Figure 27). The form of the Japanese Solar Ark building imitates the form of the Japanese traditional sword or archway. Japanese swords have a long history in which their shapes have changed many times. However, many styles of antique Japanese sword have an arc shaped scabbard and handle (see Figure 28). Different forms of sword also identified the owners. Hoso tachi, one style of Japanese sword, could be worn only by the highest ranking royal officers in ancient Japan. Thus this shape of sword can evoke cultural memories of nobility and elegance. By integrating this unique shape into the building, the architects successfully expressed a cultural meaning through this solar 
building (see Figure 29). The purity of the whole building's coloured envelope, in harmony with the unique colour of the solar panels, also conveys the Japanese spirit through the colour of the Japanese traditional archway and Zen Garden.
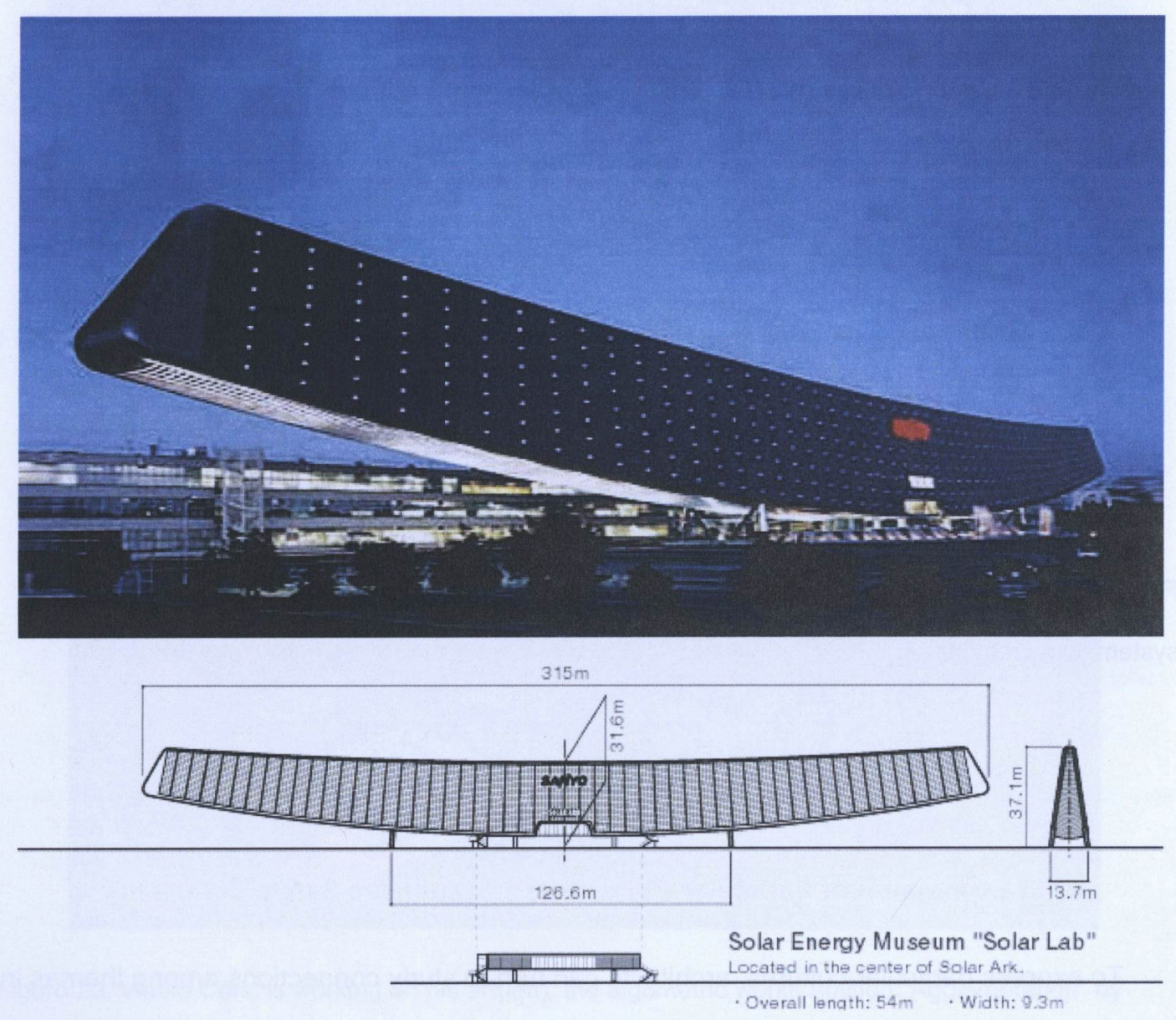

Figure 27. The Japanese Sanyo Solar Ark.

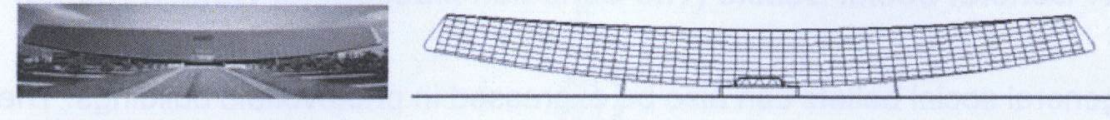

Solar Ark ( Solar Energy Museum )
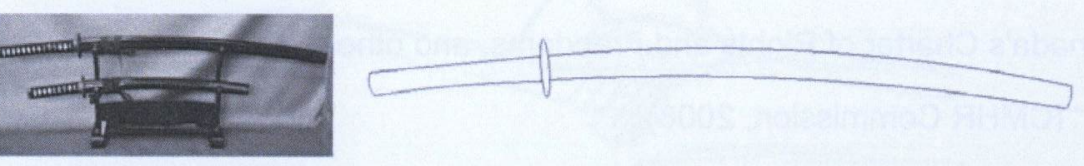

Curved Japanese sword "Katana
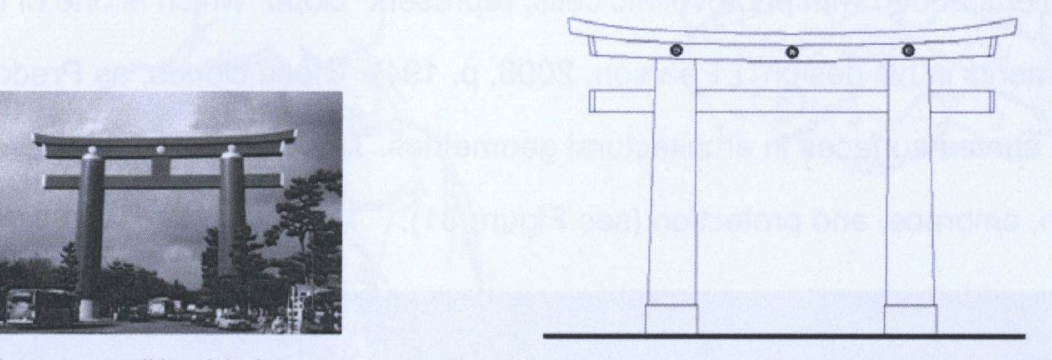

Japanese traditional Archway.

Figure 28. Form Analysis of the Sanyo Solar Ark.

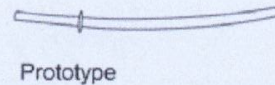

Prototype

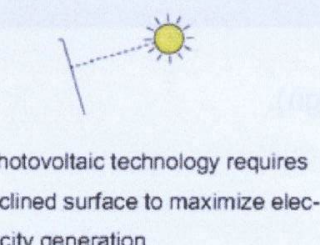

tricity generation

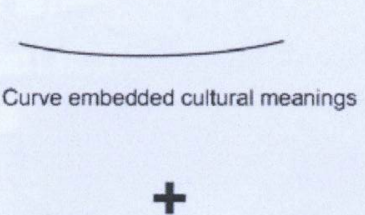

$+$

¿

Architectural symmetry completes the used space and building forms
$=$ pression
Figure 29. Morphological analysis of the Solar Ark. 


\subsubsection{General Social Beliefs (The Canadian Museum for Human Rights)}

More general social beliefs can also be expressed in photovoltaic buildings. The Canadian Museum for Human Rights, planned to be completed in 2012, is an example. This museum designed by Antoine Predock proposes to " feature, explore and promote discussion on human rights legislation such as the U.N. Universal Declaration of Human Rights, Canada's Charter of Rights and Freedoms, and other human rights legislation “ (CMHR Commission, 2008).

Conveying the notion of human rights in architecture challenged Predock who has responded by using " shingled glass to wrap several stone galleries (see Figure 30 ). The glass panels, embedded with photovoltaic cells, represent "cloud" which is one of three symbolic elements in his design" ( Pearson, 2006, p. 194). These clouds, as Predock explains, are curved surfaces in architectural geometries. This building's forms evoke the sense of faith, embrace, and protection (see Figure 31)

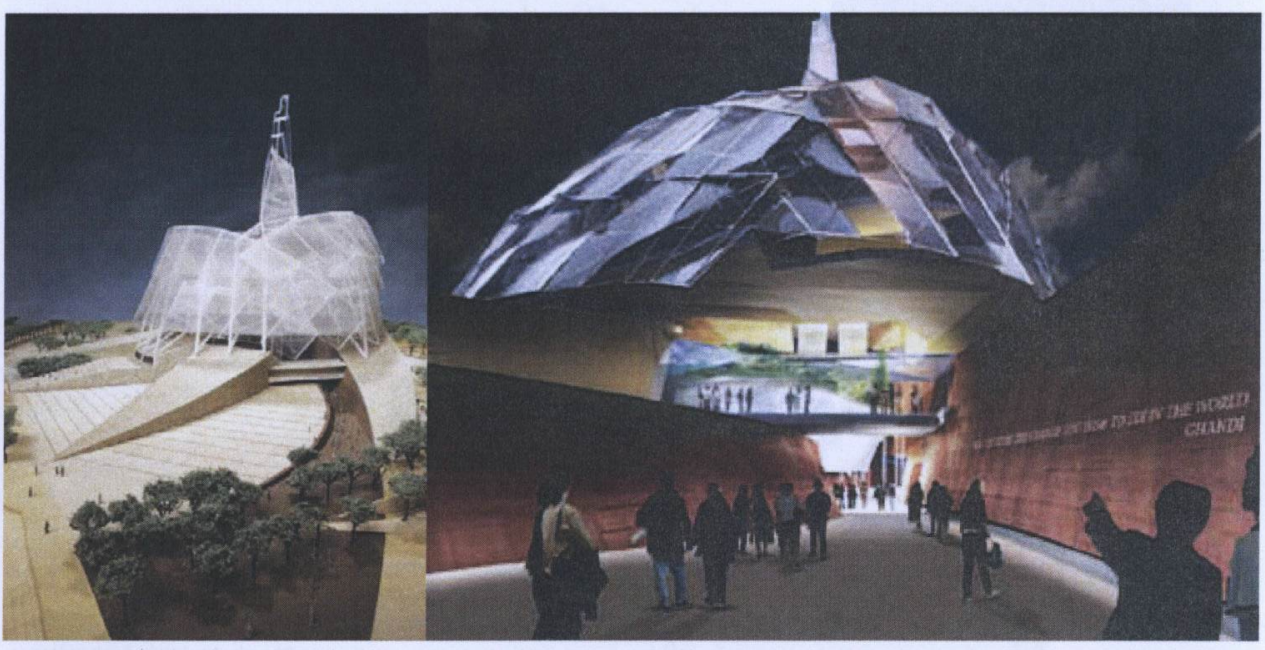

Figure 30. The Canadian Museum for Human Rights (schematic design).
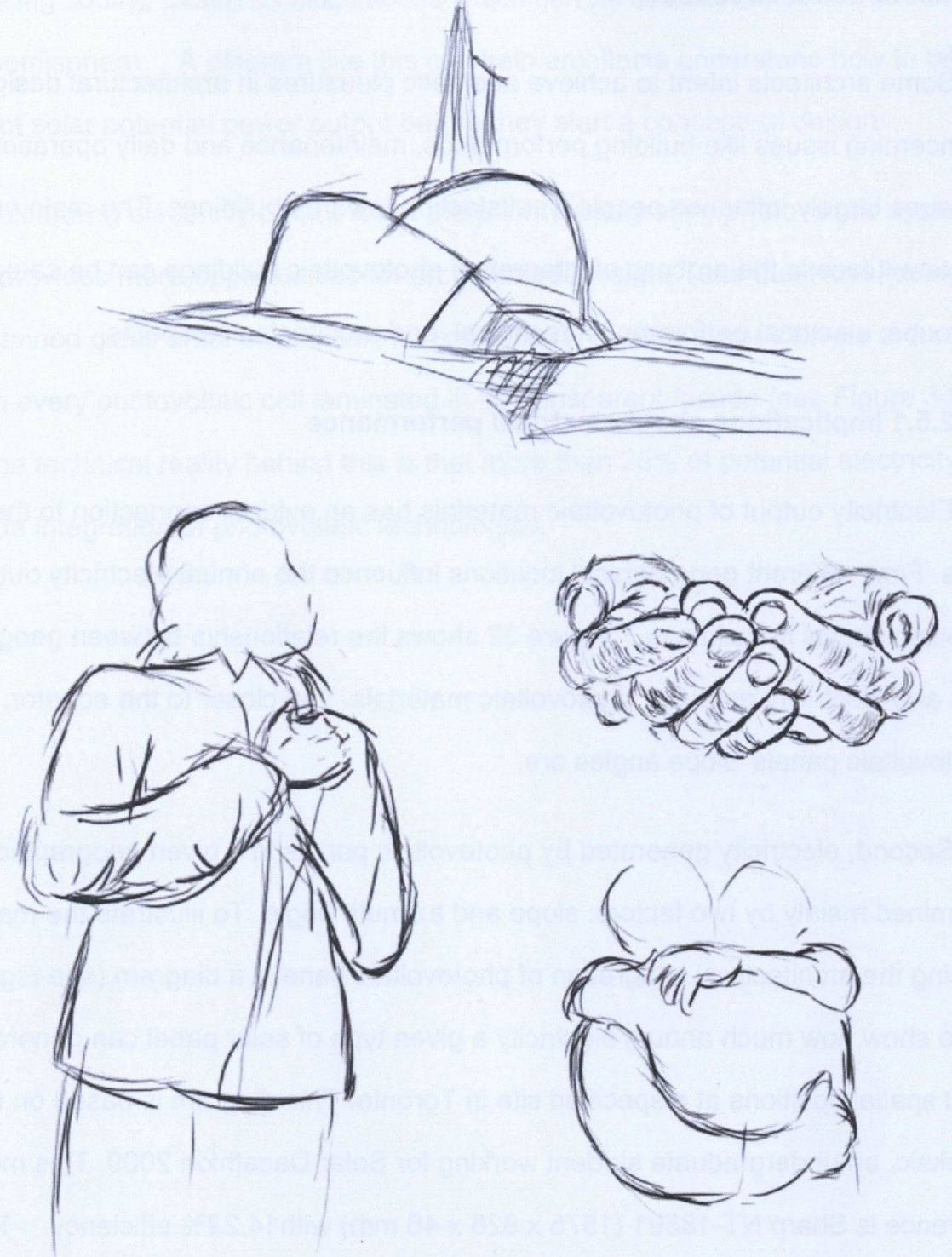

Figure 31. Form study of Canadian Museum for Human Rights ( CMHR) 


\subsection{Implications for Architects}

Some architects intent to achieve aesthetic pleasures in architectural design rather than concerning issues like building performance, maintenance and daily operation. However, these issues largely influence people's satisfaction towards buildings. The main problems architects will face in the process of integrating photovoltaic buildings can be categorized into three groups: electrical performance, technical, and architectonic aspects.

\subsubsection{Implications about electrical performance}

Electricity output of photovoltaic materials has an evident connection to the spatial surfaces. First, different geographical locations influence the annual electricity output of photovoltaic panels in buildings. Figure 32 shows the relationship between geographical location and electricity output of photovoltaic materials. The closer to the equator, the lower the photovoltaic panels' slope angles are.

Second, electricity generated by photovoltaic panels in a given geographical location is determined mainly by two factors: slope and azimuth angle. To illustrate the major factors influencing the architectural integration of photovoltaic panels, a diagram (see Figure 33) is drawn to show how much annual electricity a given type of solar panel can generate in different spatial positions at a specified site in Toronto. This diagram is based on the data of Mila Aleksic, an undergraduate student working for Solar Decathlon 2009. This module type for reference is Sharp NT-185u1 ( $1575 \times 826 \times 46 \mathrm{~mm})$ with $14.22 \%$ efficiency. The PV energy absorption rate is $100 \%$, and a $72 \mathrm{KW}$ inverter with $100 \%$ efficiency is used. Assume that $0 \%$ miscellaneous losses happen in the photovoltaic system. All the data is calculated by the software RETScreen Version 4

Every square represents a unique spatial location with a different slope and azimuth angle (no scale). The spectrum from deep red to deep blue represents the power the solar panel generates annually. The deeper red the square, the more power the solar panel in that position will generate. The deeper blue the square, the smaller the amount of electricity the solar panel in that position will generate. The optimized slope is 33 degrees with azimuth 90 degrees (facing south), based on calculations which can be seen in the centre of the Electricity hemisphere. A diagram like this can help architects understand how to take advantage of solar potential power output before they start a conceptual design.

If maximizing electricity output is not the priority, integrating photovoltaic systems into the facade provides more opportunities for architectural design. Take Lux Nova, designed by Canadian stained glass artist Sarah Hall, for example. This wind tower delivers a dream-like beauty from every photovoltaic cell laminated in its transparent facade (see Figure 34 ).

However, the technical reality behind this is that more than $25 \%$ of potential electricity will be lost in facade integration of photovoltaic technologies. 


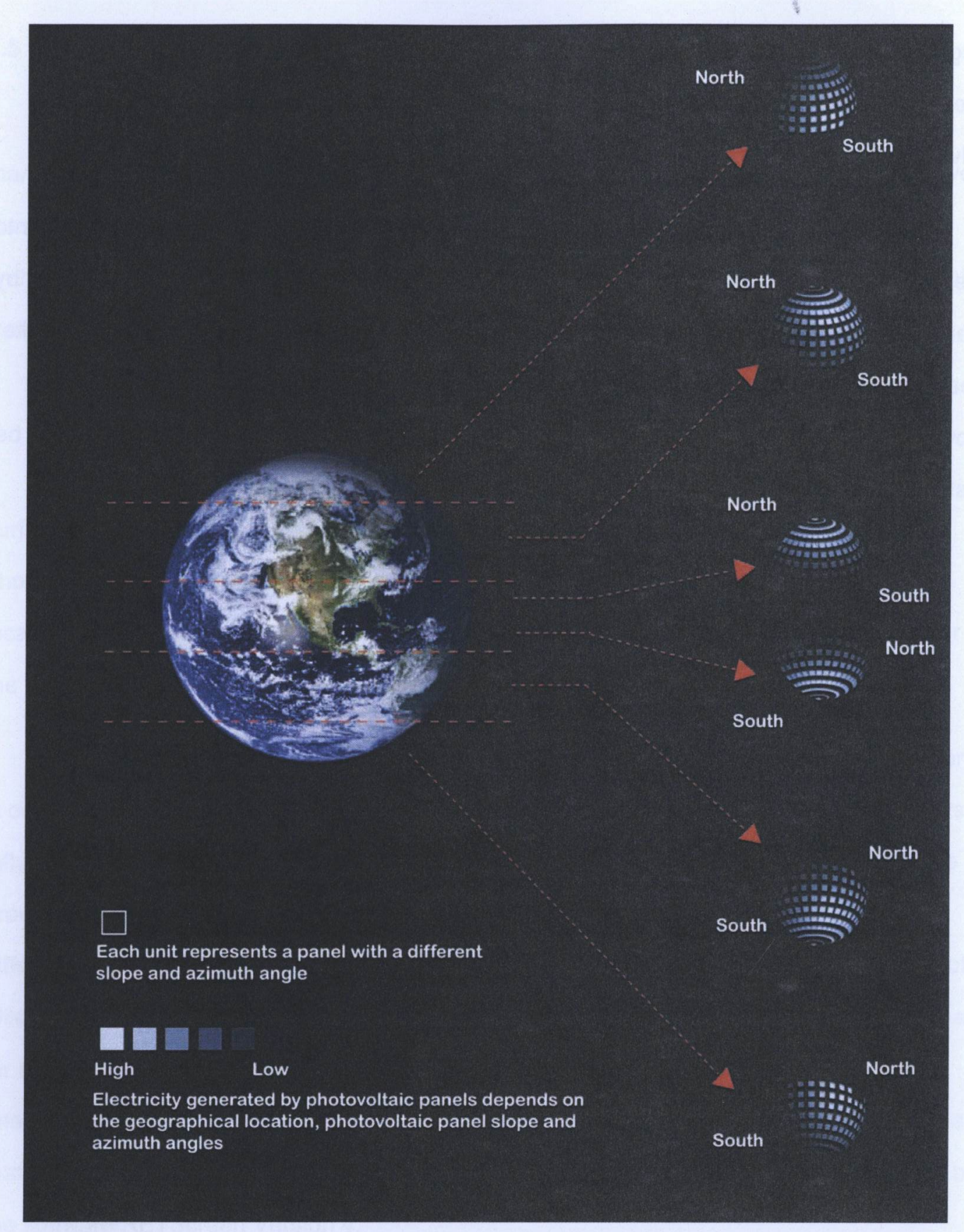

Figure 32. A diagram illustrating the relationship between photovoltaic annual electricity and geographical location
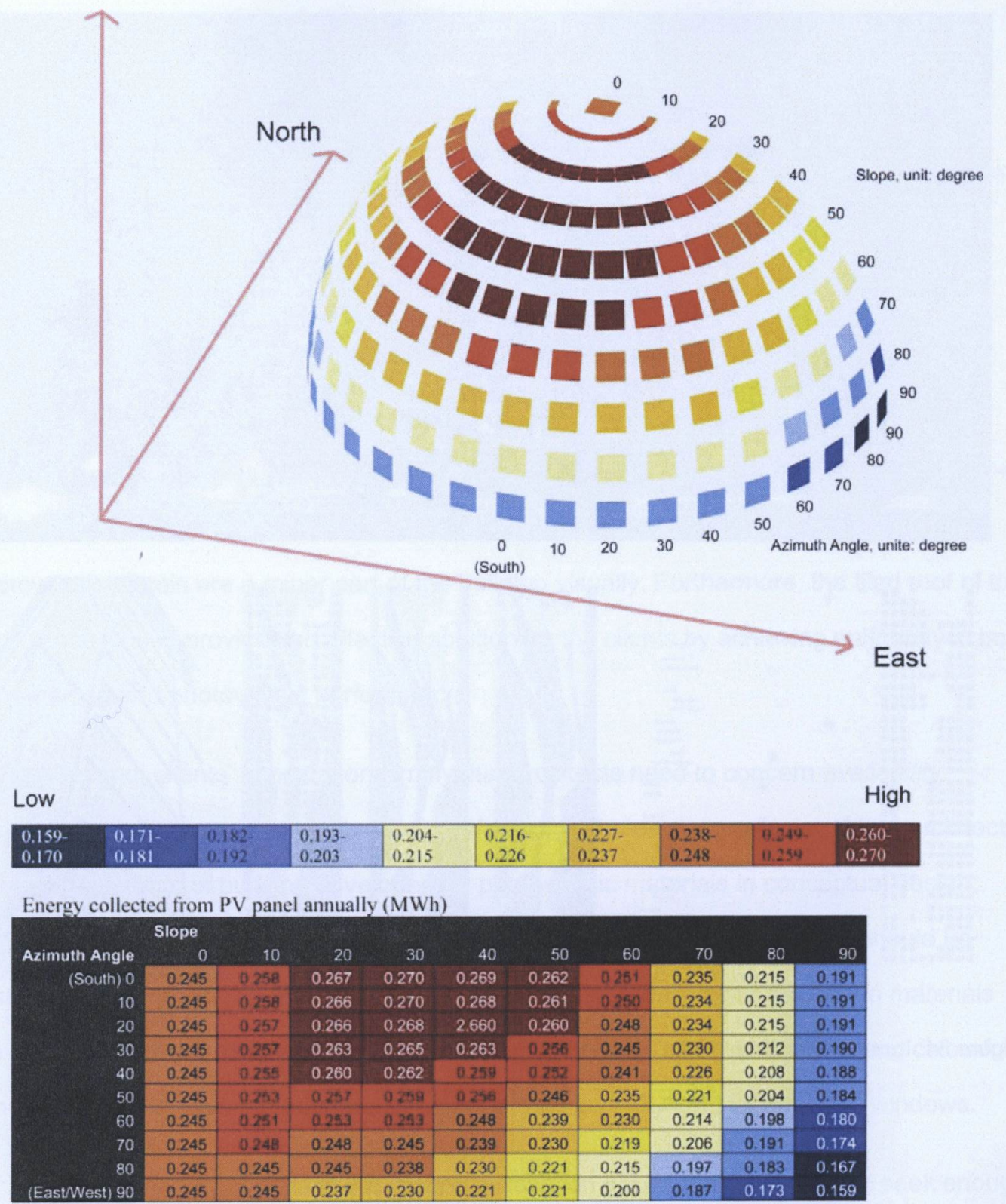

Figure 33. This diagram illustrates the relationship between annual electricity generated by a specified photovoltaic panel and its spatial locations, defined by azimuth angles and slopes. The spectrum divided into ten equal intervals, indicates the amounts of electricity from maximum to minimum, represented by blue and red squares respectively. The deeper blue the square is, the less electricity the photovoltaic panel generates. 


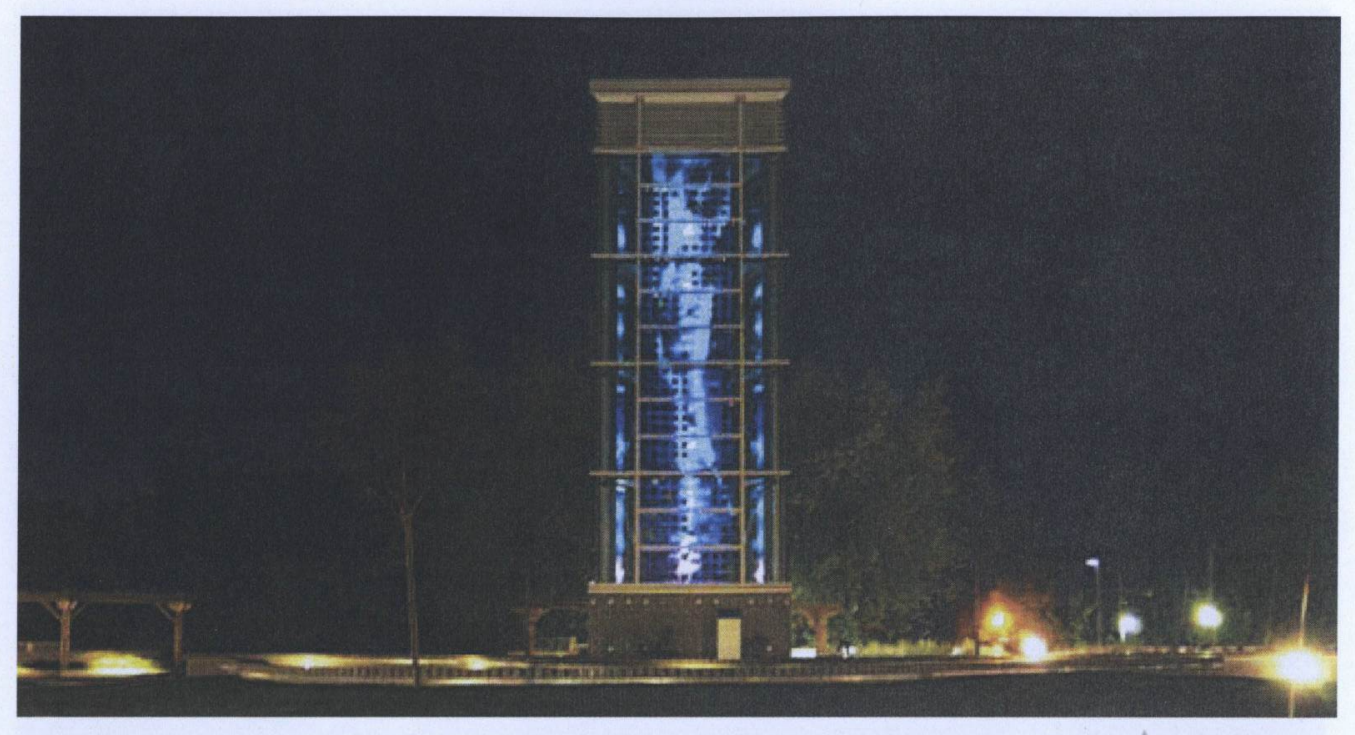

\subsubsection{Technical and architectonic implications}

If architects manage to integrate cultural meaning into photovoltaic buildings, then what other issues besides electrical performance can affect the form making of photovoltaic buildings? What potential risks will architects face in creative architectural design? The questions at hand provoke detailed discussions on technical and architectonic aspects in creative design and practice.

First, the clients' expectations are the priority in architectural integration of photovoltaic technologies. For instance, the clients' expectations for Turbulence House were not colour and transparency, but conversion efficiency of photovoltaic panels. In this case photovoltaic panels are a minor part of the building visually. Furthermore, the tiled roof of the Turbulence House provides an effective solution for the clients by achieving uniformity in both form-making and photovoltaic performance.

Second, clients' expectations imply that architects need to concern availability, accessibility and perceptibility of building surfaces for photovoltaic material. When architects seek suitable parts of building envelopes for photovoltaic materials in conceptual design availability of building surfaces including the size, consistence and orientation should be systematically considered. For instance, rigid, opaque and dull crystalline silicon materials are suitable for metal roofing systems. Comparably, flexible, semi-transparent and colourful thin film materials have the potential to be integrated with skylight, facade, and windows

One primary challenge in the rooftop renovation at London City Hall is to seek enough area for photovoltaic modules (see Figure 17). The building was designed as a passive solar building as architects didn't expect to add new components to the rooftop. Consequently, the photovoltaic rooftop of the oval building tiling facing north brings difficulty for the optimization of electrical performance.

Accessibility of building surfaces for photovoltaic material refers to the idea that photovoltaic panels integrated into buildings should be easily accessible for cleaning and maintenance. Lack of proper consideration for accessibility degrades photovoltaic 
performance. For example, the large tiled photovoltaic roofs in Solarsiedlung community (Figure 9) post a problem of accessibility. The affordable design, due to its standardized photovoltaic arrays, expose fragile, slippery and inaccessible glass roofs presenting considerable difficulties for cleaning and maintenance. The major implication for accessible photovoltaic roofs is that structural supports for photovoltaic modules need to be simple, durable and sturdy.

Perceptibility of building surfaces for photovoltaic material refers to the manner that photovoltaic materials are publicly visible. For facade integrated photovoltaic buildings, dialogue between other building components and photovoltaic materials in colour, pattern and texture should be carefully considered in a rational manner. Spinnereistrasse in Vorarlberg, Austria is an example of inspiring architectural composition in photovoltaic buildings (see Figure 35). Visible dark blue photovoltaic modules are regarded as facade panels that seek equilibrium and harmony with other building components. In addition, the notion of photovoltaic architecture is feasible because the price to performance ratio is satisfying (Himanshu, 2004).

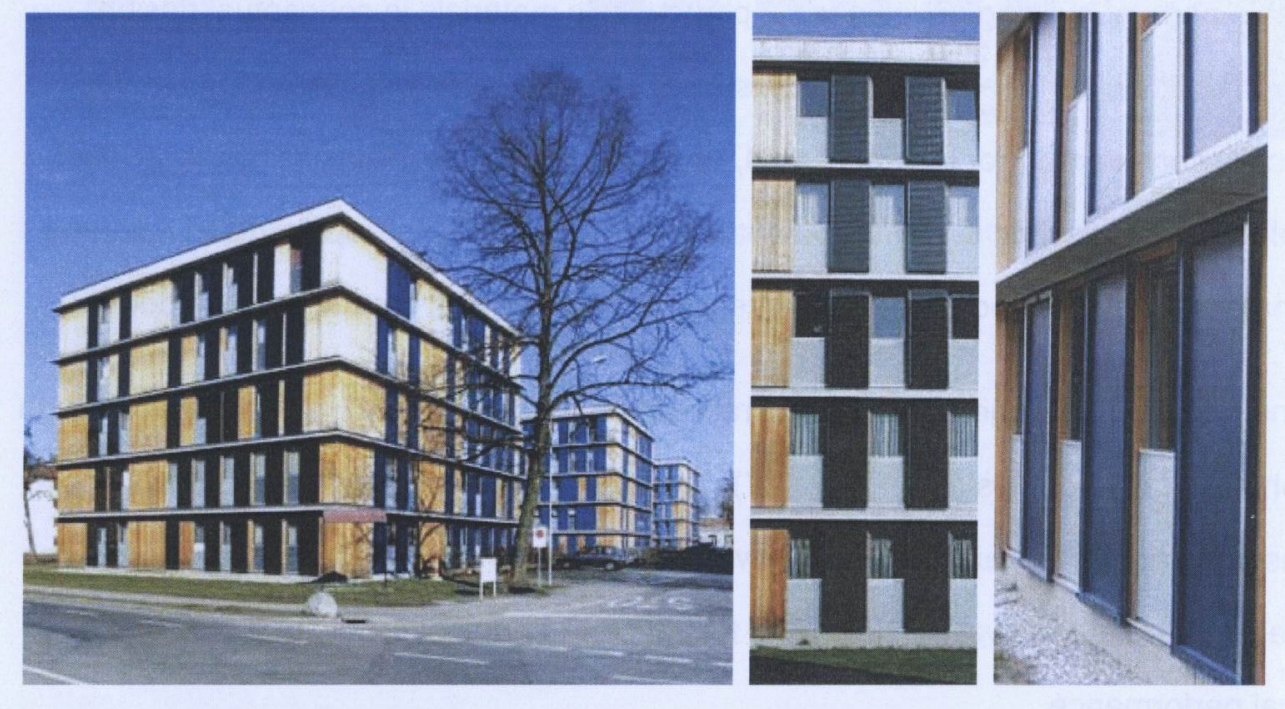

Figure 35. Spinnereistrasse in Austria: façade integrated with thin film photovoltaic panels.

Thirdly, alternative functions of photovoltaic materials should be taken into consideration. In the Spinnereistrasse project, the photovoltaic modules, produced by
German solar company stromaufwärts, do not perform major insulating functions so the facade still requires insulating layers. Roof integrated photovoltaic modules also raise questions about seeking additional layers for insulation and moisture protection. For instance, the idea of a photovoltaic roof challenges various architectural performances such as thermal comfort, lighting and insulation in Mont-Cenis-Academy. The academy's envelope was designed as a transparent "shell" resistant to solar radiation, rain, and wind. On the rooftop photovoltaic panels perform only few functions of a conventional roof. Architects had to provide feasible solutions for interior thermal comfort by either constructing "buildings in building" or attaching other insulation layers to photovoltaic roofs in a conceptual design. In addition, an interior pool was designed to collect rainwater through a specified system or by leaking from the canopy.

Fourthly, complex photovoltaic systems may generate difficulties in construction, maintenance and electric performance therefore increasing initial costs. The inconsistent arrangement of photovoltaic panels generates difficulties in technical integration. For architectural form-making different convex slopes occurring along a short length can cause difficulties in photovoltaic integration. Responding to these technical limitations, Steinhude Sea Recreation Facility has relatively gentle slopes when integrating convex surfaces with rigid photovoltaic modules. In addition, using standard photovoltaic modules will reduce complexity and installation costs.

Finally, the awareness about building surfaces triggers a further discussion on suitable building types for photovoltaic materials (see Table 2). Table 2 analyzes the potential for photovoltaic materials integrated into various building types. Different building types supply possible building surfaces with various spatial positions while at the same time providing architects with the potential to express cultural and artistic motifs. For instance, a residential building in an urban environment has relatively less potential than a museum at the same urban context to express cultural meaning. Therefore the potential building types may provide for photovoltaic materials needs be exploited. 
Successful integration of cultural and artistic ideas with photovoltaic materials relies on a comprehensive understanding of these implications. A diagram assisting architects in decision-making on photovoltaic building designs is shown in Table 3. However, architects must realize that these technical and architectonic implications cannot constrain creative architectural thinking. Otherwise, architects will easily shift to functionalism.

\subsubsection{Outlook for the solar technologies}

Photovoltaic materials are becoming cheaper, thinner, and more flexible. In 1985, the University of New South Wales in Australia developed a solar cell with $20 \%$ efficiency. Now this number has doubled. The current record for conversion efficiency of solar cells is $40.7 \%$, held by the National Renewable Energy Laboratory (NREL), which means 1 square metre of photovoltaic panel in a $1000 \mathrm{Kw} / \mathrm{m} 2$ region can generate a 407 watt electricity maximum (IEA, 2007) . Martin A. Green, one of the best known researchers into photovoltaic systems, classifies the development of this fast growing technology for electricity generation into three stages. In his book, Third Generation Photovoltaic materials : Advanced Solar Energy Conversion (2006), he argues that the first generation of photovoltaic systems used silicon wafer as its base material, reaching its limit on cost and production. Thin film technology, the second generation, uses fewer materials than its predecessor, offering advantages in low cost and mass production. The third generation, which Green deems will rely on tandem cells, will lower overall costs and raise the conversion efficiency. Figure 36 illustrates the performance-price ratio of the three generations. This trend provides architects with insight into how active solar building design will evolve.

The colours of photovoltaic materials are also a challenge today. Besides photovoltaic cells, some engineers have begun to explore other characteristics of photovoltaic material, bringing a new perspective on photovoltaic systems. For instance, researchers in Covalent Solar have suggested the novel idea of using simple glass or plastic panels laminated with common outdoor dyes. Photovoltaic cells wrapping the edges of glass or plastic panels can reach conversion efficiencies of up to $6.8 \%$. This system also can absorb diffuse light, working without a tracking or cooling system. (Currie, 2008,) Innovative photovoltaic materials will inspire and encourage architects in the building integration of photovoltaic materials.

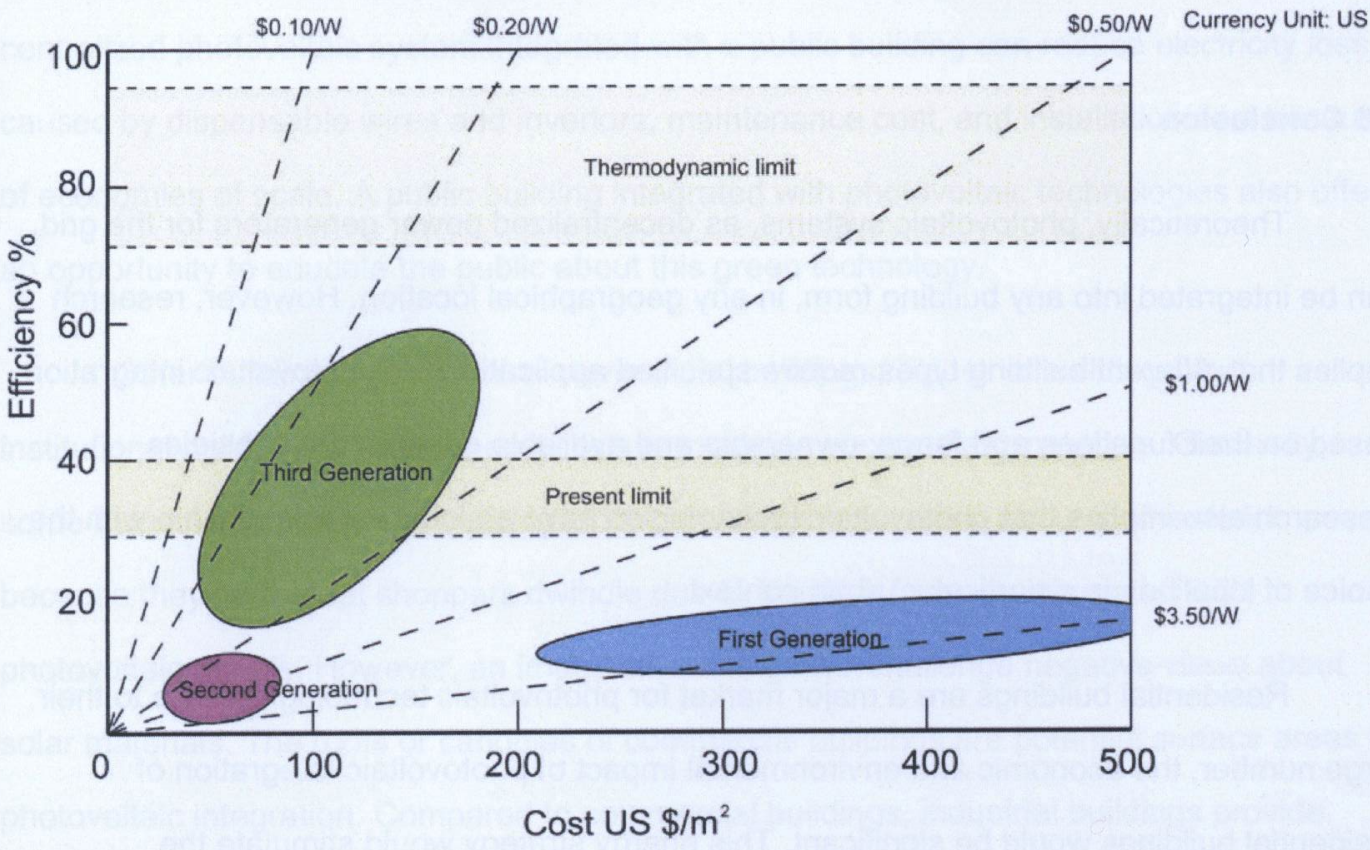

Figure 36. Efficiency-cost trade off for the three generations of solar technology: wafers, thin films,and advanced thin films ( year 2003; cost in US\$). Redrawn and revised by the author. Source: Green, Martin A. (2006). Third Generation Photovoltaic materials. P3. Figure 1.2.

Average architects usually are adaptors rather than inventors (Reyer, 1980). They have been and are trained to arrange available technologies and materials to create a material world for societies with cultural, aesthetic, and emotional expression. The trends in photovoltaic systems tell architects that the integration of photovoltaic systems into buildings has considerable future potential. The forms of photovoltaic building will not be rigid, following only the technology-driven approach; on the contrary, they will vary in spatial dimension. Any shape of building surface can be produced with the second or third generation of photovoltaic systems because of their low costs or high efficiency or both. Just like the evolution of aluminum use today, new developments of photovoltaic systems will have a promising future with economy of scale. The building types integrated with photovoltaic collectors will be 
diverse, from institutional to residential. Even small buildings, such as vendor stands, bus stops, and tents, will have photovoltaic systems mounted on them.

\subsection{Conclusion}

Theoretically, photovoltaic systems, as decentralized power generators for the grid can be integrated into any building form, in any geographical location. However, research implies that different building types require specified applications of photovoltaic integration based on their functions and forms, ownership and available government subsidies.

Research also implies that photovoltaic technologies have an inherent relationship with the choice of locations in a particular urban context.

Residential buildings are a major market for photovoltaic technologies. Due to their large number, the economic and environmental impact of photovoltaic integration of residential buildings would be significant. This energy strategy would stimulate the development of solar energy technologies. Currently, the main market for photovoltaic technologies is small scale residential buildings such as houses, townhouses and mid-rise apartments. Architecturally, the traditional prototype of a house with tilted roofs benefits photovoltaic technologies, and the façade of residential buildings also offers areas for photovoltaic integration. However, maximizing daylight in residential buildings limits the possible installation areas for photovoltaic panels because the window areas dominate the facade. This tradeoff increases both the difficulties of architectural integration and the solar electricity cost because photovoltaic integration of residential buildings needs more electronic invertors and longer wires connecting invertors with dispersed solar panels than large scale integration to generate the same amount of electricity; in addition, the power output will drop slightly due to longer wires.

In addition to low rise residential buildings, large scale public buildings are also potential areas for photovoltaic technologies. A large scale public building integrated with photovoltaic technologies, compared to a house, can generate more power because it offers more installation areas. A large scale public building can reach the electricity capacity of 100 KWp, the threshold between a large scale power plant and a small scale one (Goetzberger, 2005 , p. 126), and is more meaningful economically. Besides the larger electricity capacity, a centralized photovoltaic system integrated with a public building can reduce electricity loss caused by dispensable wires and invertors, maintenance cost, and installation cost because of economies of scale. A public building integrated with photovoltaic technologies also offers an opportunity to educate the public about this green technology.

Other building types such as commercial buildings, industrial buildings and institutional buildings also have potentials to integrate photovoltaic materials. Generally, some owners of commercial buildings in urban area are selective about their exterior because they worry that shoppers dwindle due to the dark frontage integrated with photovoltaic panels. However, an imaginative design will challenge negative views about solar materials. The roofs or canopies of commercial buildings are potential surface areas for photovoltaic integration. Compared to commercial buildings, industrial buildings provide designers with more exterior surface for photovoltaic integration. High efficiency and good performance are the two priorities in photovoltaic integration of industrial buildings. As a result, the panels should be installed on the roof, which reduces the design opportunities to showcase photovoltaic technologies to the public.

The basic requirement for photovoltaic integration is that there is no shading in the site. Based on this principle, agricultural areas are a natural fit for photovoltaic technologies, except that this would consume valuable land areas.

Urban areas without shading are also appropriate for photovoltaic integration. Urban areas that dominated by high rise buildings could also be potential locations for photovoltaic integration with careful shade analysis of surrounding buildings. Admittedly, the limited shading-free surface areas are a major barrier to integrating solar technologies in urban environments. However, the significance of photovoltaic integration in urban areas, compared to suburban areas, is the educational purpose it serves. 
The landscape of a city transforms over time. Building structures remain the same but their function changes over the years. In many post-industrial cities, old industrial low-rise buildings that have been changing their functions would be appropriate sites for photovoltaic integration.

The research implies that urban areas in post-industrial cities should be explored as possible sites for photovoltaic integration. With government subsidies, photovoltaic buildings in cities or even a solar city could be possible.

\section{A recreational facility integrated with photovoltaic technologies}

\subsection{Overview}

The following section is a proposed architectural design developed by the author based on the research presented in this thesis. The project, titled a Recreational Facility Integrated with Photovoltaic Technologies, presents form exploration and architectural intervention. The application of the research is understood through the process of this design. The intention is to present: First, the importance of interaction between building forms and photovoltaic materials in conceptual design. Second, how the architectural theme is conveyed. Thirdly, how relevant details of the building can be sophistically developed to achieve an efficient solution.

To find a meaningful project for photovoltaic technologies three major aspects must be considered including topographical, economic and social feasibility. Topographical feasibility emphasizes the solar analysis of the site which helps to determine the appropriate area for the proposed building during a year. Economic feasibility refers to the comparison of energy generation and consumption of the proposed building while questions like whether the energy generation is significant compared with the energy consumption of the building have to be framed to judge the proposed project. Social feasibility is assessed and determined through investigating demographics of local communities and public demands on building space. This step-by-step logic and reasoning is the basis and criteria for the design project.

Based on the three aspects, the author selected Lamport Stadium Recreational Park -- one of numerous green spaces in Toronto -- as the proposed site. This site contains an aged stadium, a green space and various municipal parking lots. The major topographical character of the neighbourhood is the flatness of urban fabric consisting of low rise office buildings and industrial parks (see Figure 37,38 ). There are around 20 conifers and other deciduous trees five to 12 metres tall mainly distributed along the west and east edges of the site. An historic house is located on the northwest corner on the King Street W. The economic 
and architectural significance of this area for photovoltaic technologies is based on the idea that public facilities can be transformed into electrical generators in an urban context. For a city, a network of this installation will promote solar energy as a sustainable resource in an urban environment

Historically this area was used for prisons followed by a major industrial centre (Wieditz, 2007). After urbanization in recent decades, the neighbourhoods were gradually transformed into an art centre accommodating various industries related to arts such as furniture design (Green design studio), radio (Sirius), and 3D film (Geneva Film Co). Rising employment and distinctive landscape drove young professionals to move into this area therefore promoting local economic activity and recreational opportunities. As a public green space the existing Lamport Stadium Park fails to service new residents in the area. These social and geographical factors, combining with solar shading analysis, make the proposed site an ideal place for proposing a new recreational facility integrated with photovoltaic technologies

Objectives and building programs presented in this section address the technical and architectural challenges of photovoltaic integration with building forms to maximize electricity generation. These challenges are constructed based on the research and investigation of the site. Form exploration examines the objectives and building programs determined in the previous process. The research presented in Section One guides form exploration with criteria such as electricity generation, urban context, structure, flexibility for various technologies and building programs.

An explicit form model generated in the previous step has to be integrated with an architectural theme to develop an elaborate design. In the process of architectural intervention the author integrated aspects such as expressive ideas, thermal insulation, structure, solar control, dimension, proportion, scale, details of the building, mechanical systems and electronic systems as a whole. This process, depending largely on individual imagination and experience, would lead to various designs. For example, the proposed design project concentrates on the idea of integrating photovoltaic technologies with daylight, rain collection, patio and expressive structure into a cubic form. The architectural theme is to express the shape of energy flow, the weightlessness of a photovoltaic roof and the dynamic photovoltaic façade.

Information of the proposed site was obtained and gathered following several site trips from March to April, 2009, Maps and Data at Ryerson University, statistics data from the City of Toronto, Google Earth and the Bing Maps system. The key findings in this design are summarized in Section Four. 

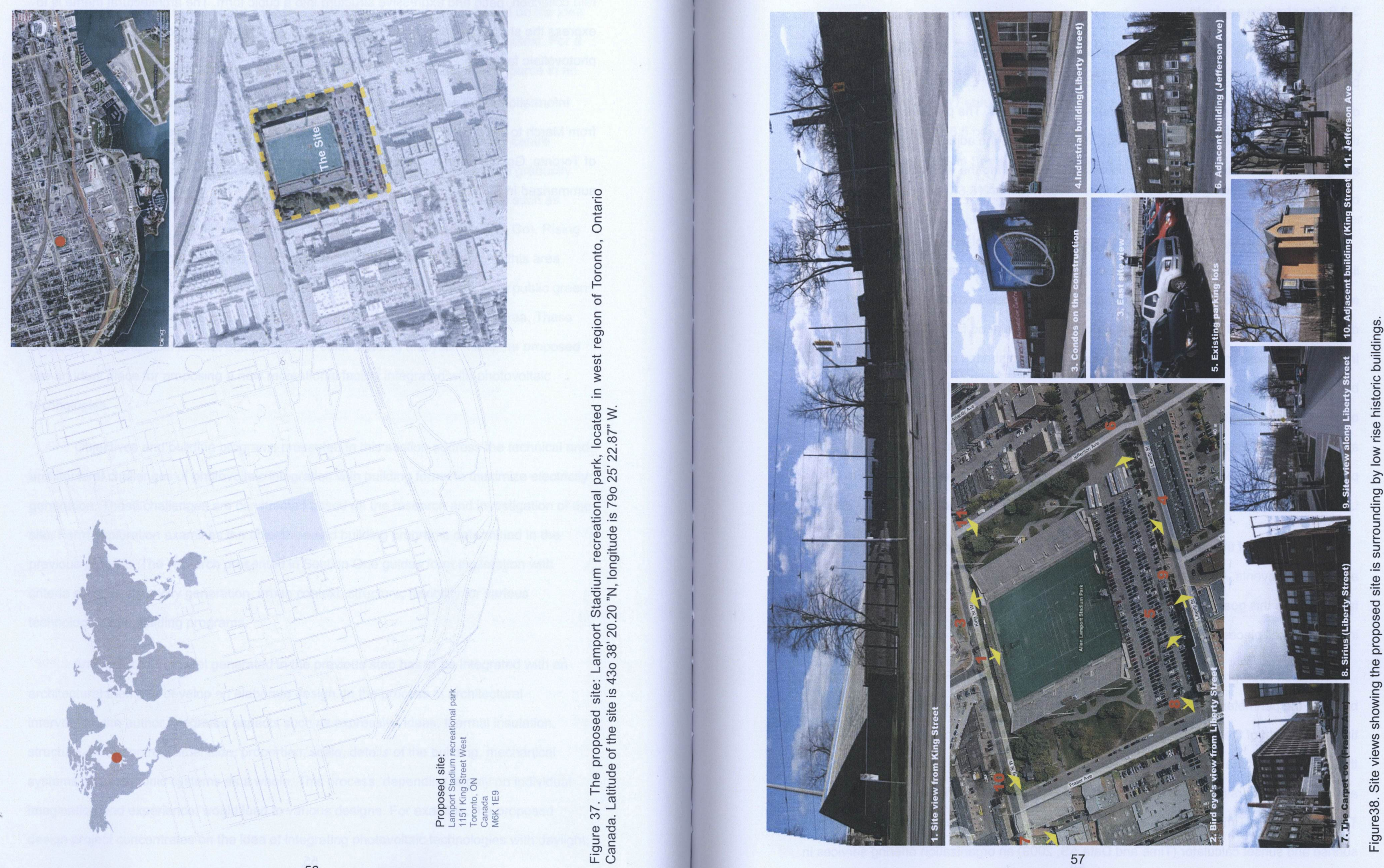


\subsection{Solar shading analysis}

Shading analysis is an essential phase for solar building design. During the conceptual phase architects can use simulation tools such as Sketchup or Ecotech to generate a

diagram showing the area available for photovoltaic materials. The process helps determine the appropriate area for proposed buildings. In this process, the adjacent buildings vegetation along with other tall structures, that could cast shadows during the year should be taken into consideration.

Usually, locations available for photovoltaic integration in mixed-use urban areas are limited due to the considerable height of the adjacent buildings or vegetation. Finding an appropriate site for the photovoltaic integration in urban areas becomes important. The diagrams in Figure 39 illustrates that the proposed site is a good fit for photovoltaic integration because most parts of it are annually free from shades of adjacent low rise buildings. In addition, only the perimeter of the site would be shaded from large conifers and other deciduous plants that are around five to 12 metres tall (see Figure 38 for the site views and Figure 40 for area appropriate for photovoltaic integration). Solar analysis implies three potential shade-free parts in the chosen area for the photovoltaic integration: close to the Liberty St. (south), at the centre of the site, or close to King St. W (north).

The intention of the design is to provide local residents with convenience of engaging in activities and events. A proposed location close to Liberty St. or in the centre of the site wil fail to achieve this goal. Another concern of a central location is that the whole site divided into three small pieces lacks flexibility for hosting large events.

The area appropriate for photovoltaic materials is illustrated in Figure 40. The distance between the perimeters of the suitable area and the adjacent trees is designed at least 1.5 times the height of these trees. Since the adjacent buildings do not cast continuous shade on the chosen part of the site, sunrise and sunset times in Toronto can be approximately taken as the daytime hours for this design project. Table 4 shows the sunrise and sunset times for Toronto's Eastern Time Zone in 2009. The data calculated and collected through an online sunrise and sunset calculator (Time and Data AS, 2009) an organization offering services in time zone calculating and seasonal calculation. Based on the data collected in Table 4 an estimation of solar hours for the chosen site can be summarized as follows: Toronto

averaged less than nine daylight hours (37.5\% daily) at the chosen part of the site in January 2009; 10 hours, 41.7\% in February; 11 hours, 45.8\% in March; 13 hours, 54.2\% in April; 14 hours, $58.3 \%$ in May; 15.5 hours,64.6\% in June; 15 hours, $62.5 \%$ in July; 14 hours, $58.3 \%$ in August; 12 hours, $50 \%$ in September; 11 hours, $45.8 \%$ in October; 9 hours, $37.5 \%$ in November; and 8 hours, $33.3 \%$ in December. As shown in the bar graph (Figure 40) daily solar radiation at the site is higher in the summer than in the winter. The best months for solar radiation and long solar hours are May, June, July and August during a calendar year. 

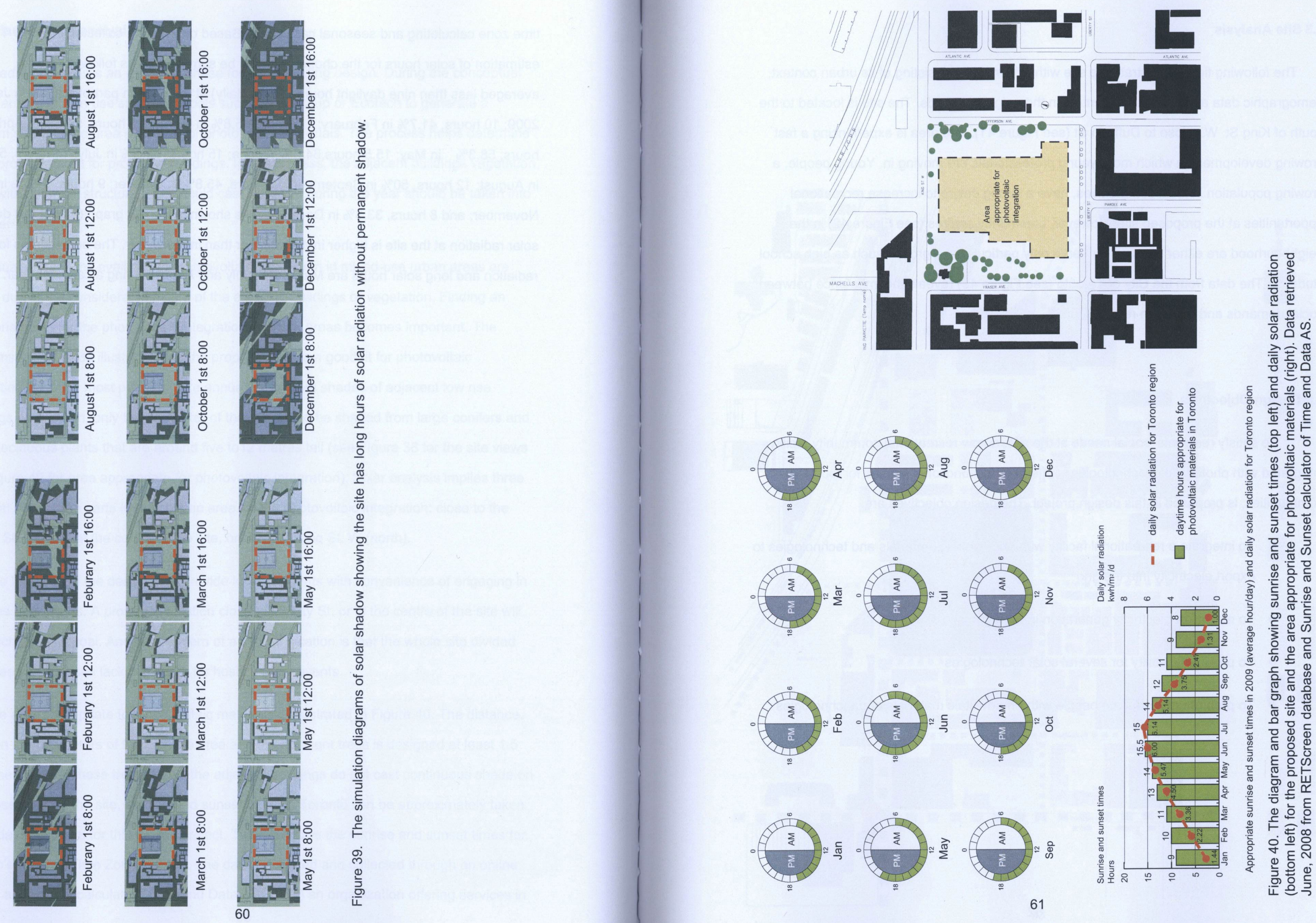


\subsection{Site Analysis}

The following figures illustrate the site with information consisting of its urban context, demographic data and community centres in the neighbourhoods. The site is located to the south of King St. W., close to Dufferin St (see Figure 41). The area is experiencing a fast growing development in which more young professionals are moving in. Young people, a growing population in local communities, have a strong desire to increase recreational opportunities at the proposed site. However, community centres (see Figure 42) in the neighbourhood are either too small or serve only particular age groups such as high school students. The data from the City of Toronto (see Figure 43) reveals the imbalance between social demands and supply in recent years.

\subsection{Design Objectives}

To satisfy residents' social needs at the site, a new recreational community facility -integrated with photovoltaic technologies -- offering multifunctional spaces for local communities, is proposed in this design project. The design objectives are:

- To integrate a recreational facility with photovoltaic materials and technologies to export electricity into the grid

- To maximize electricity generation in the proposed site

- To provide flexibility for several solar technologies

- To promote and educate people with photovoltaic materials and technologies

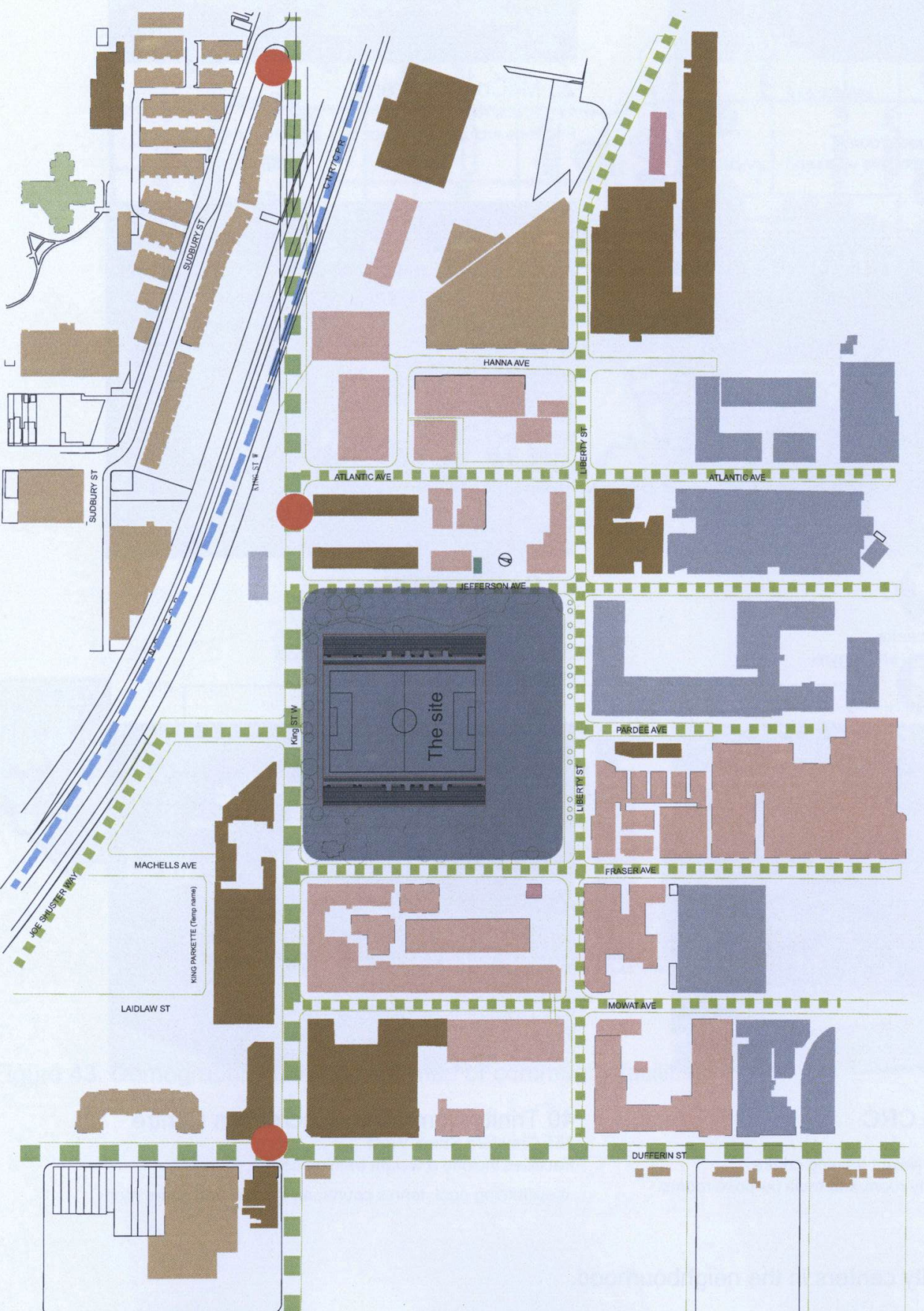




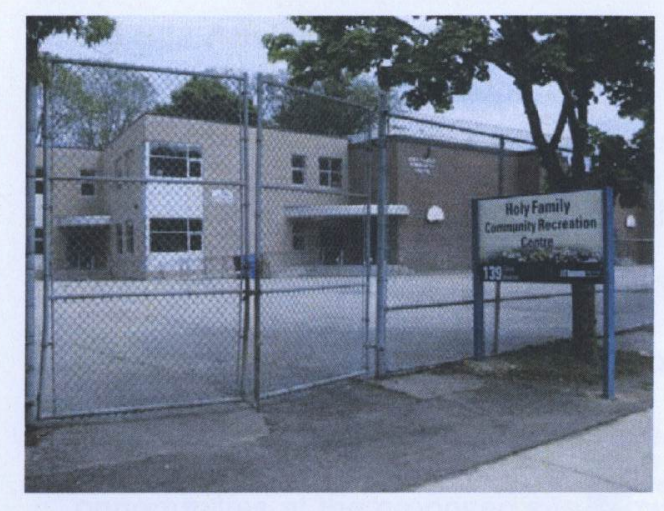

16 Holy Family

Facilities include multi purpose rooms,

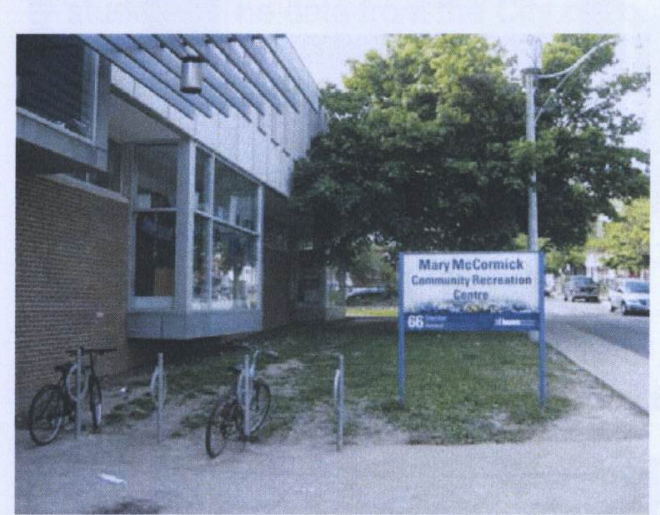

21 Mary McComick RC

Facilities include a fitness centre,
swimming pool, weight room, and a gym

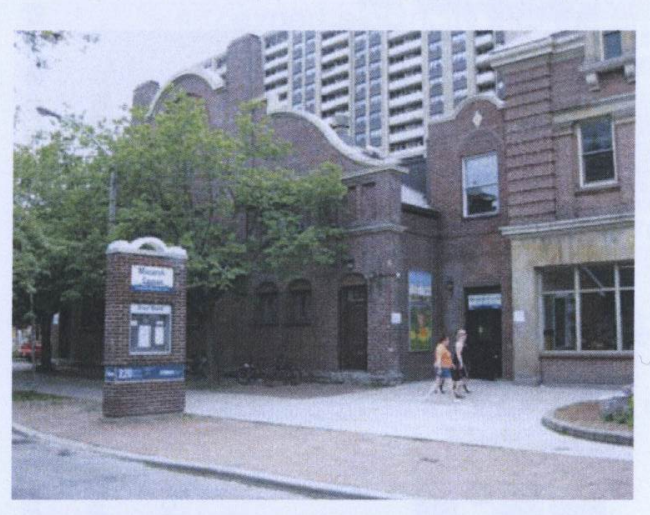

22 Masaryk Cowan CRC

Facilities include a gym, a weight training centre.

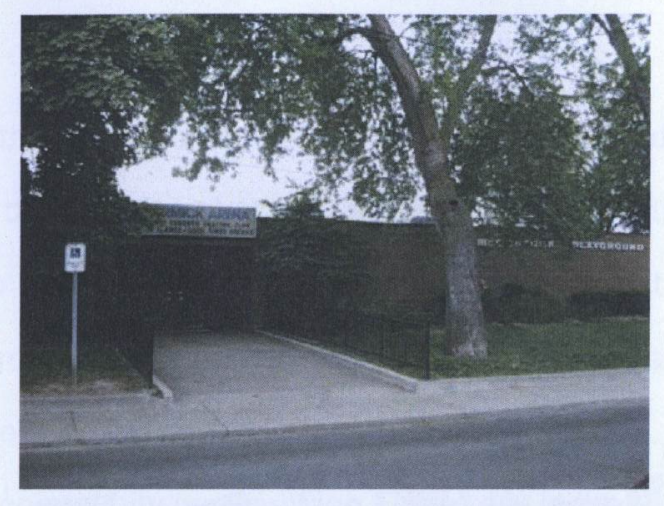

25 McComick Arena

Facilities include an indoor and an outdoor ice rink

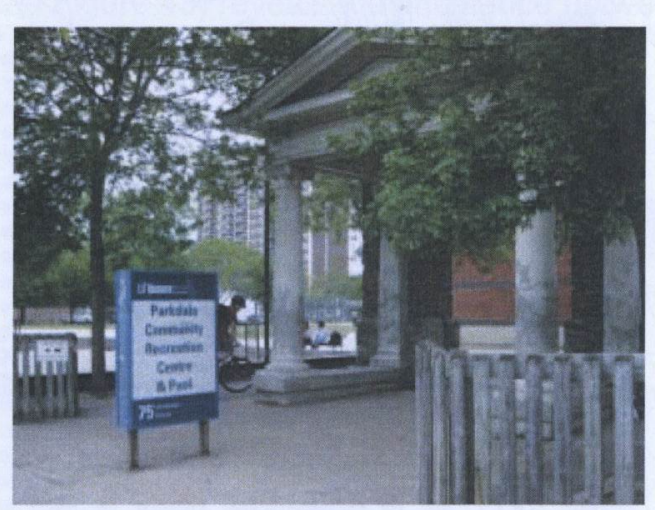

27 Parkdale CRC

Facilities include multi purpose rooms,

2 gyms, and 2 indoor swimming pooss

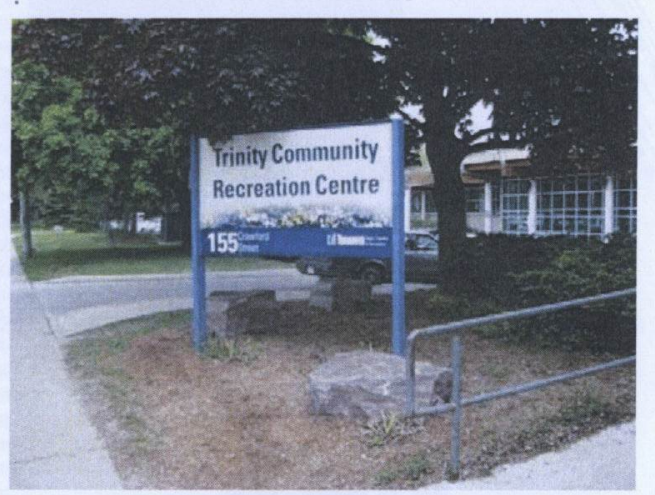

40 Trinity Community Recreation Centre Facilities include a weight training centre.
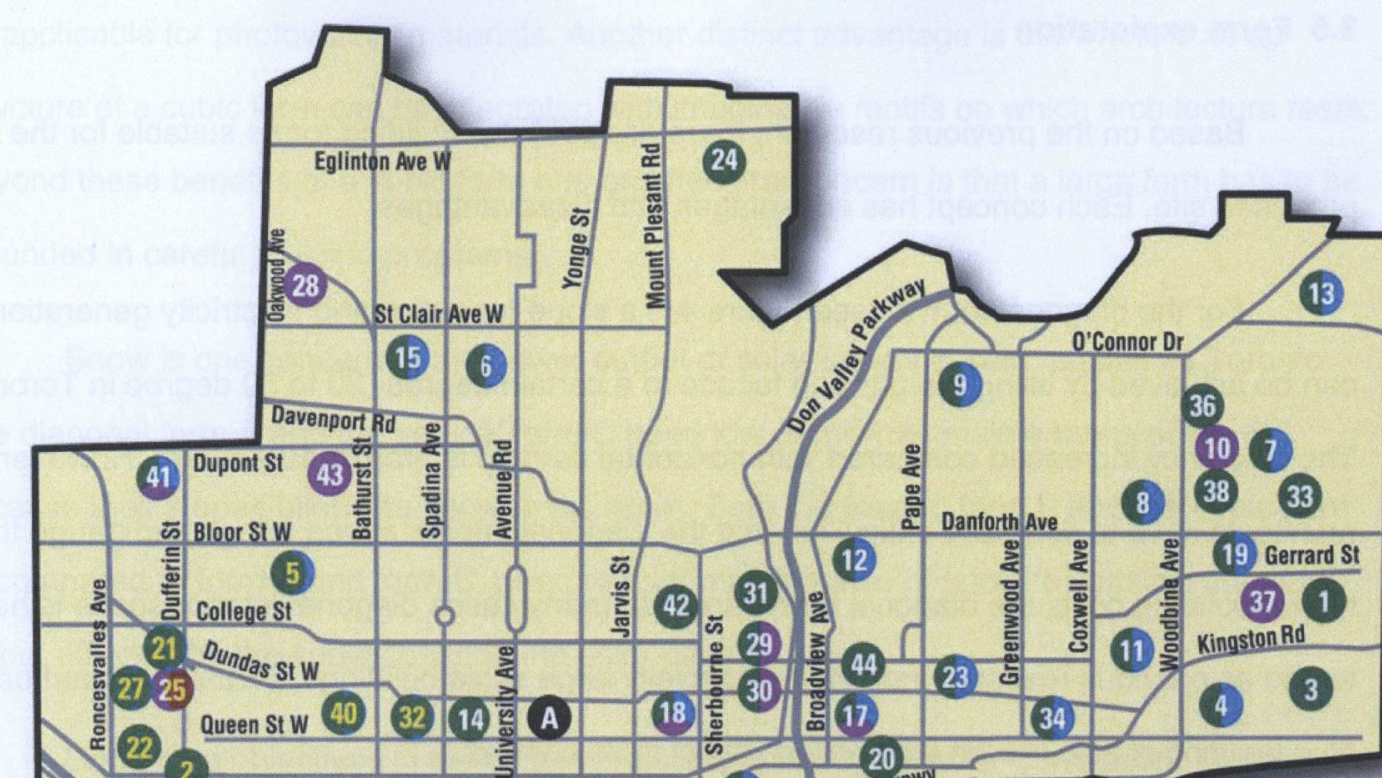

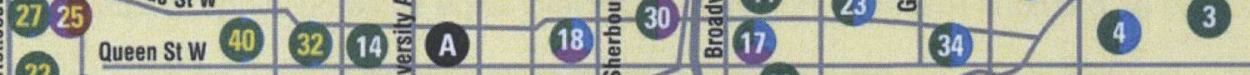

16 King St W(26) FrontstW

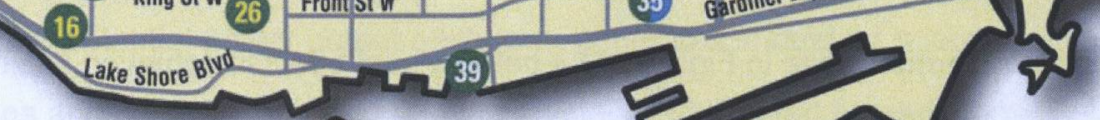

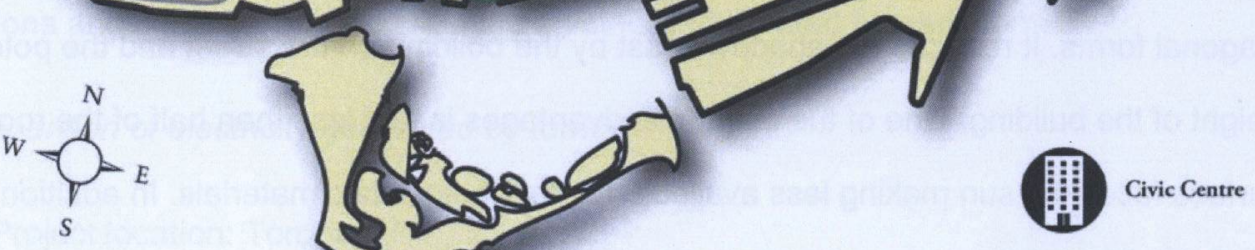

$0=$
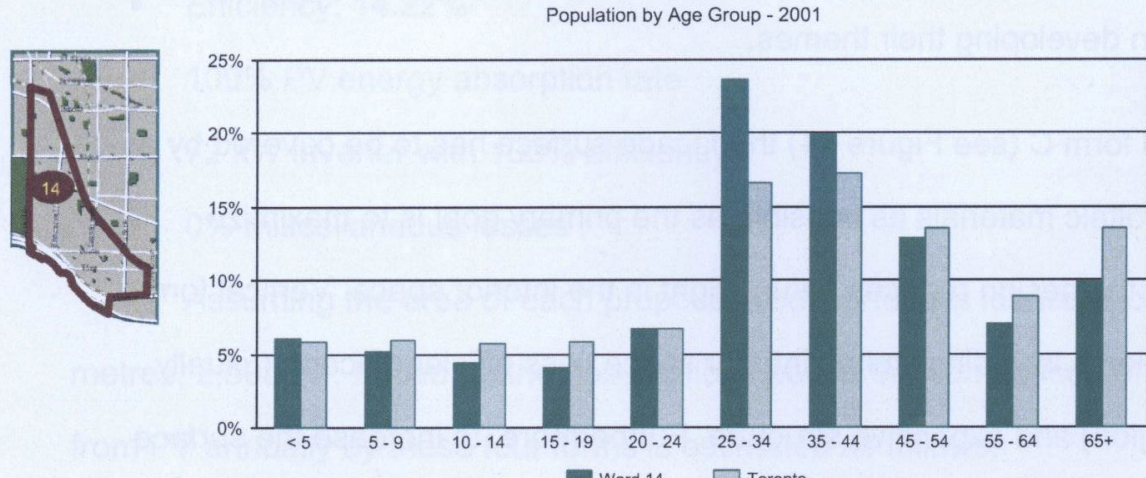

(9)

$20 \begin{aligned} & \text { Swimming Pool } \\ & \text { (indoors \& outdoors) }\end{aligned}$ 


\subsection{Form exploration}

Based on the previous research, there are potential building forms suitable for the proposed site. Each concept has advantages and disadvantages.

For the diagonal form A (see Figure 44) a slope for optimizing electricity generation can be achieved by tilting the building facade to a certain degree- 20 to 30 degree in Toronto. The efficiency increased compared with horizontal surface is around 10 percent. However, architects have to solve the difficulties that the diagonal interior space brings and gauge the higher building costs the diagonal form brings. In many cases diagonal interior space is hard to use as previous research indicates, especially large scale buildings. Visually, a giant dark blue building is also like an extraneous object to its context.

For waving forms B (see in Figure 44) a better visual effect is achieved easier than diagonal forms. It reduces the shadows cast by the building on the street and the potential height of the building. One of the major disadvantages is that less than half of the roofs surface faces the sun making less available for flat photovoltaic materials. In addition, the angle of slopes has to be designed to avoid shadows on the rear slope caused by the front slope. For other free forms the same problems exist for architects who tend to synthesize the building components in developing their themes.

For the vertical form C (see Figure 44) the facade surface has to be covered by as many powerful photovoltaic materials as possible as the primary goal is to maximize electricity. As a result, the design reduces natural light in the interior space. Vertical forms also raise design problems including limited interior space, less efficient facade (usually $60-70 \%$ in Toronto region) and expensive structure. Furthermore, to increase the surface area available for photovoltaic materials, the height of the building has to be high responsively which, in return, casts a large shadow over King St.

For the cubic form D (see Figure 44) the roof offers a fine surface to install various photovoltaic materials. The height of the cubic form can be lower to avoid casting large areas of shadow in comparison to the diagonal form and the vertical form. Some facades can also be applicable for photovoltaic materials. Another distinct advantage is the whole built-up structure of a cubic form can be integrated with imaginative motifs on which architecture rests Beyond these benefits of a cubic form one architectural concern is that a large form has to be grounded in careful building programs.

Snow is one concern to the power output of solar panels in cold regions as Toronto. The diagonal form $A$ and the vertical form $C$ need low or minimal maintenance of snow because their slopes allow the snow to fall down. Both the waving form $B$ and the cubic form $\mathrm{D}$, compared to form $\mathrm{A}$ and form $\mathrm{C}$, need regular maintenance of snow to stabilize the power output affected by the snow covering the solar panels.

One of the objectives in the design project is to maximize solar generation. To achieve this goal, the potential power output each form generates should be examined. The following calculations and comparisons describe the electricity generated by each form.

Comparison of electricity generated by forms:

- Project location: Toronto

- Solar module: Sharp NT-185u1 $(1575 \times 826$ × $46 \mathrm{~mm})$

- Efficiency: $14.22 \%$

- $100 \%$ PV energy absorption rate

- $72 \mathrm{~kW}$ inverter with $100 \%$ efficiency

- $0 \%$ miscellaneous losses

Assuming the area of each proposed roof surface is identical to 50 metres $\times 50$ metres, $2,500 \mathrm{~m}^{2}$. Based on the assumptions above the comparison of energy generated from PV annually by these four forms is estimated as follows: 


\begin{tabular}{|c|c|c|c|c|}
\hline & $\begin{array}{l}\text { Roof surface available } \\
\text { for photovoltaic } \\
\text { materials }\end{array}$ & $\begin{array}{c}\text { Slope } \\
\text { (degree) }\end{array}$ & $\begin{array}{l}\text { Azimuth Angle } \\
\text { (degree) }\end{array}$ & $\begin{array}{l}\text { Electricity generated } \\
\text { estimated annually } \\
\text { (MWh) }\end{array}$ \\
\hline $\begin{array}{l}\text { Diagonal } \\
\text { form (A) }\end{array}$ & $\begin{array}{l}50 \mathrm{~m} \text { (width) } \times 50 \mathrm{~m} \\
\text { (Length); around } 1700 \\
\text { units of PV panel }\end{array}$ & 30 & 10 & 459 \\
\hline $\begin{array}{l}\text { Waving } \\
\text { form (B) }\end{array}$ & $\begin{array}{l}\text { Less than } 25 \mathrm{~m} \text { (width) } X \\
25 \mathrm{~m} \text { (Length) when } \\
\text { three tilted roof surface } \\
\text { toward the south; } \\
\text { around } 680 \text { units of PV } \\
\text { panel }\end{array}$ & 30 & 10 & 183.6 \\
\hline $\begin{array}{l}\text { Vertical } \\
\text { surface } \\
\text { (C) }\end{array}$ & $\begin{array}{l}50 \mathrm{~m} \text { (height) } \times 50 \mathrm{~m} \\
\text { (Length), around } 1700 \\
\text { units of PV panel }\end{array}$ & 90 & 10 & 324.7 \\
\hline $\begin{array}{l}\text { Horizontal } \\
\text { surface } \\
\text { (D) }\end{array}$ & $\begin{array}{l}50 \mathrm{~m} \text { (width) } \times 50 \mathrm{~m} \\
\text { (Length), around } 1700 \\
\text { units of PV panel }\end{array}$ & 0 & 10 & 416.5 \\
\hline
\end{tabular}
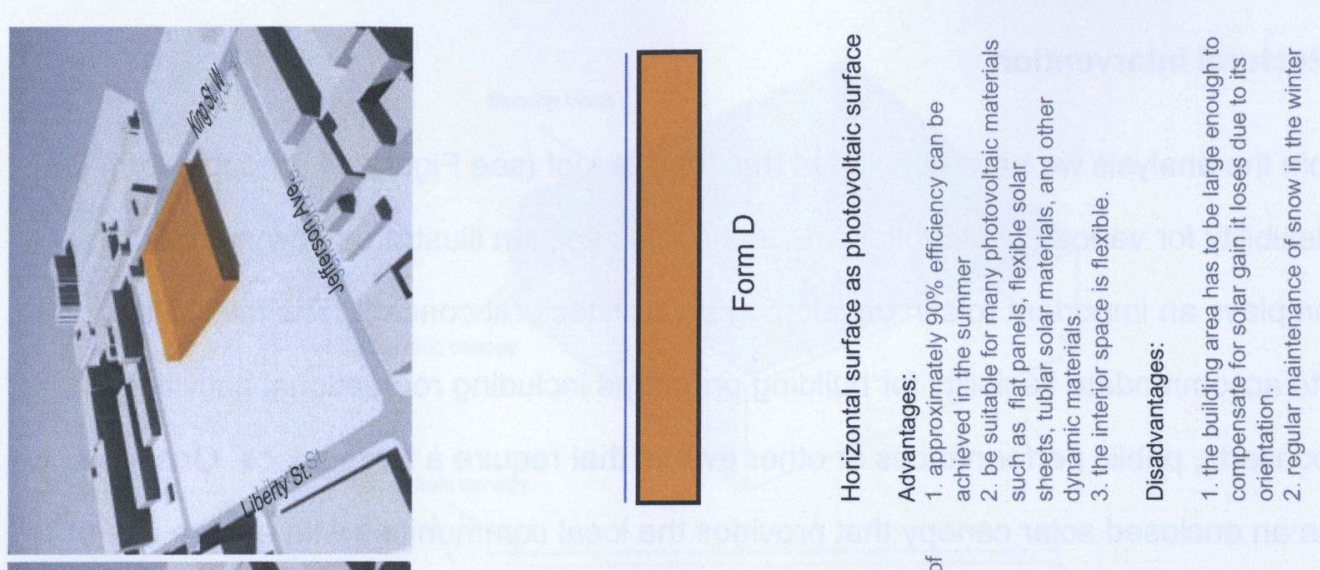

From the estimation we can conclude that diagonal form $A$ and horizontal form $D$ are appropriate options for this objective. However the height of diagonal form A reaches more than 29 metres when the building dimensions are 50 metres $X 50$ metres, which casts stress on pedestrians on King St, W. In addition, the massive diagonal building will be standing in an obtrusive position towards its neighbourhoods. Based on the analysis the author decided to choose the cubic form.
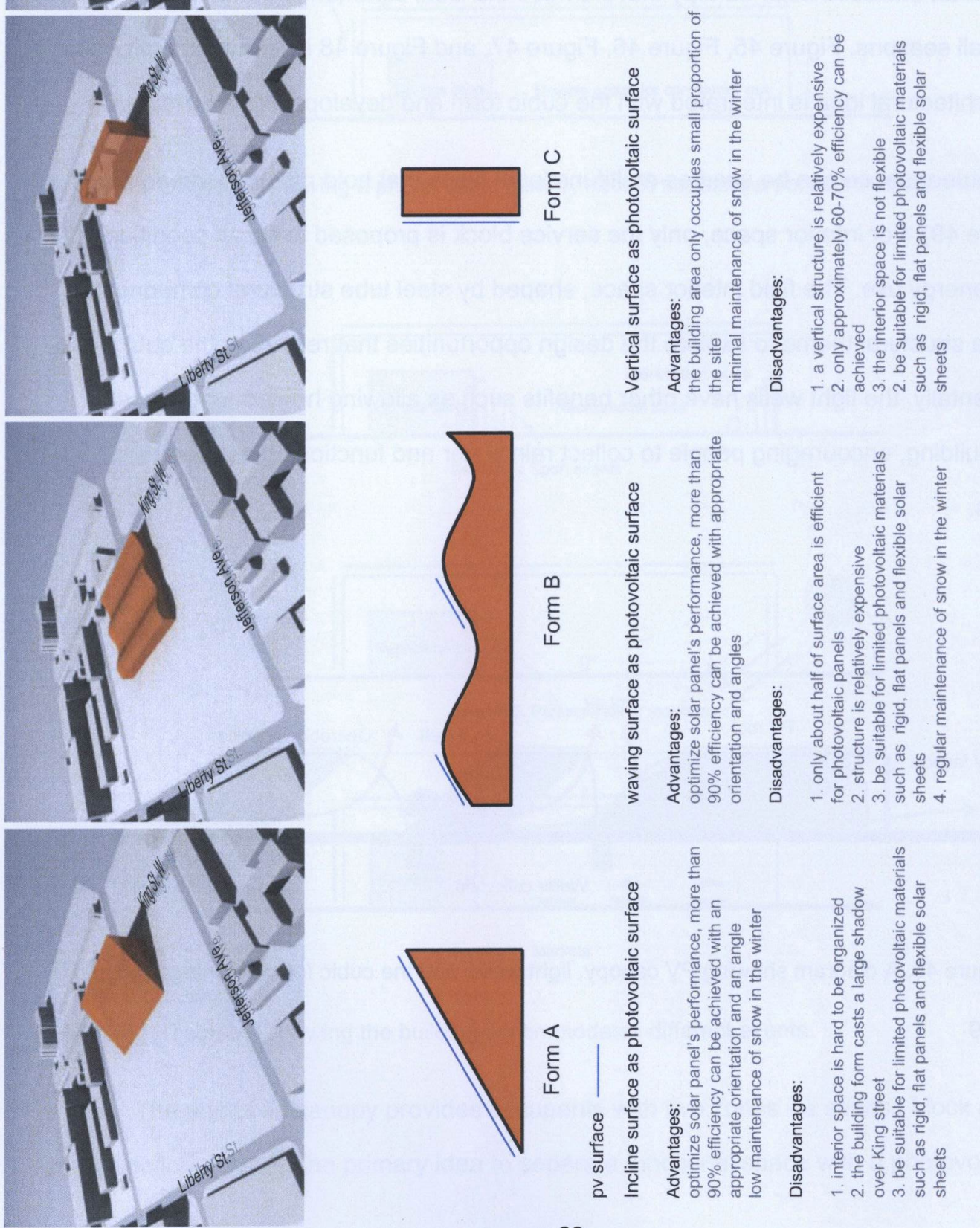


\subsection{Architectural intervention}

From the analysis we have concluded that the flat roof (see Figure 44 for cubic form D) provides flexibility for various photovoltaic materials. This section illustrates how architectural intervention plays an important role in developing an architectural concept. The facility is proposed to accommodate flexibility for building programs including recreational activities, markets, concerts, public performances or other events that require a large space. One idea is to design an enclosed solar canopy that provides the local communities with a large event space for all seasons. Figure 45, Figure 46, Figure 47, and Figure 48 illustrates the process that an architectural idea is integrated with the cubic form and develops into a building.

Outdoor space can be used as multifunctional fields that hold many sports activities (see Figure 49). For interior space, only the service block is proposed to be air conditioned to minimize energy use. The fluid interior space, shaped by steel tube structural components, develops a structural theme to explore the design opportunities that rest upon the cubic form. Environmentally, the light wells have other benefits such as allowing heated air to escape from the building, encouraging people to collect rain water and functioning as green courtyards.

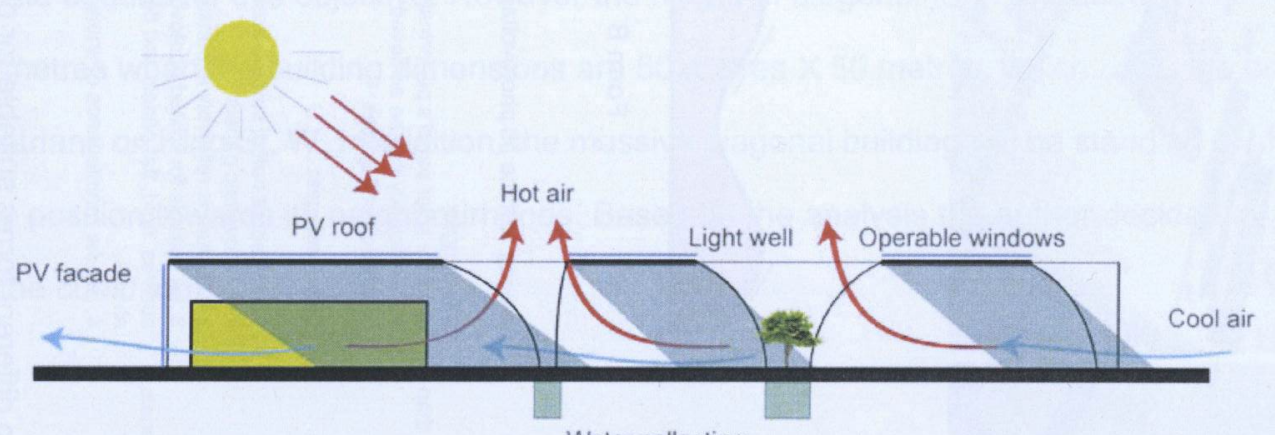

Water collection

Figure 45. A diagram showing PV canopy, light wells, and the cubic form are integrated into one building.

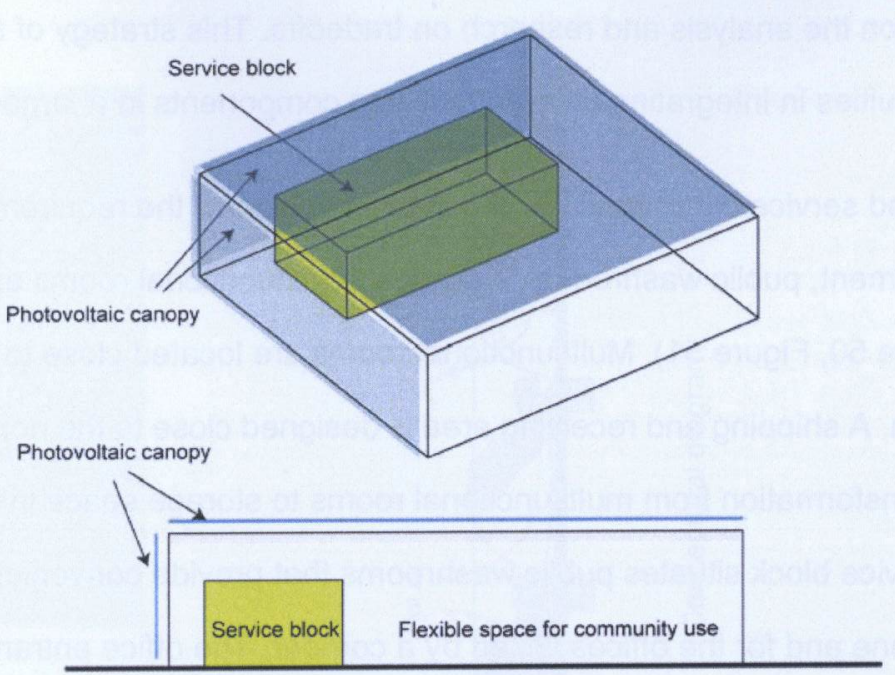

Figure 46. Diagrams showing a photovoltaic canopy accommodating a service block and flexible space for community use.

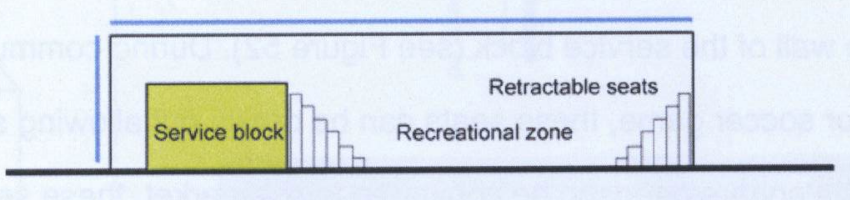

Season A. Sport events

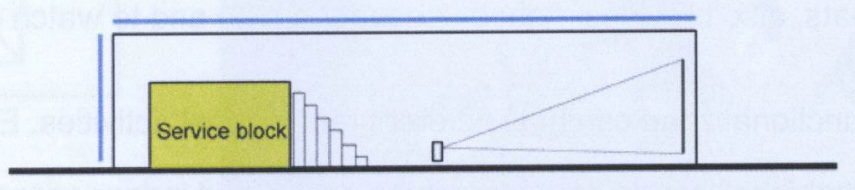

Season B. Performance or movie events

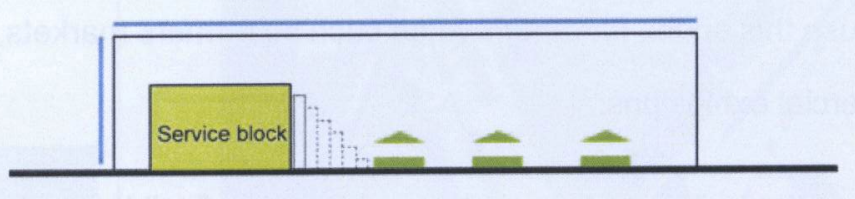

Season C. Markets

Figure 47. Diagrams showing the building accommodates different events.

The enclosed canopy provides occupants with two zones - a service block and a multifunctional zone. The primary idea to separate functional space with a photovoltaic 
canopy is based on the analysis and research on tradeoffs. This strategy of separation

reduces the difficulties in integrating different building components in a large-scale building.

A proposed service block consists of essential space for the requirements of building property management, public washrooms, storages, multifunctional rooms and a fitness centre (see Figure 50, Figure 51). Multifunctional rooms are located close to King St. W. to benefit circulation. A shipping and receiving area is designed close to the northwest entrance, allowing easy transformation from multifunctional rooms to storage space in the future. The middle of the service block situates public washrooms that provide convenience for the multifunctional zone and for the offices linked by a corridor. The office entrance is located at the west part of the building to maintain privacy.

The south part of the service block contains a mechanical room, an electrical room, a communication room and a fitness centre for local residents. Some retractable seats can be placed against the wall of the service block (see Figure 52). During community events like a basketball or indoor soccer game, these seats can be drawn out allowing spectators to enjoy the game. When the square needs to be converted into a market, these seats can be retracted to give additional space. The rooftop of the service block, linked by the spiral stair and retractable seats, also provides a good space for a café and to watch games.

The multifunctional zone can hold different recreational activities. Enough space is provided for two basketball courts, four badminton courts and indoor soccer fields at the same time. Public performances can also be held in the multifunctional zone. The local communities can use this space for other events such as farmers markets, small business markets or commercial exhibitions.

A key idea of the building's energy design is that the flexible internal space is not fully heated or cooled. In the summer it is ventilated by opening the facade instead of air conditioning, and in winter only the service block is heated and other space relies on passive solar gain. This idea aims to reduce the energy consumption of the whole building.

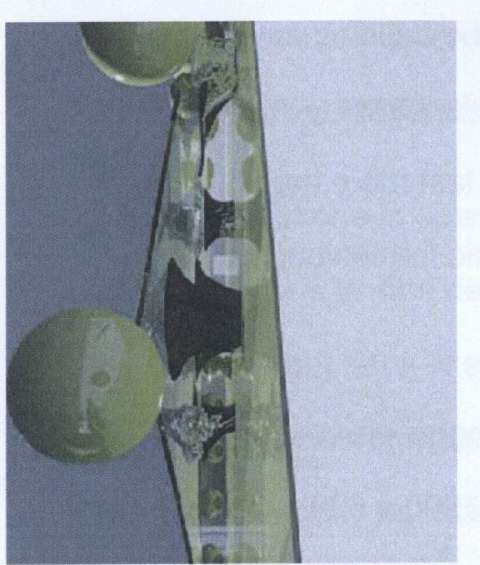

II
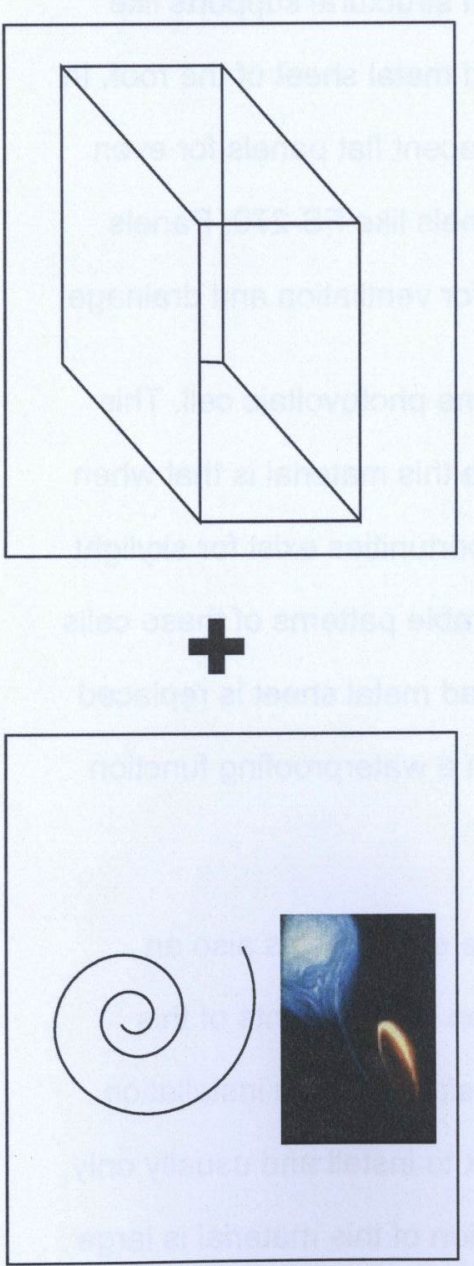
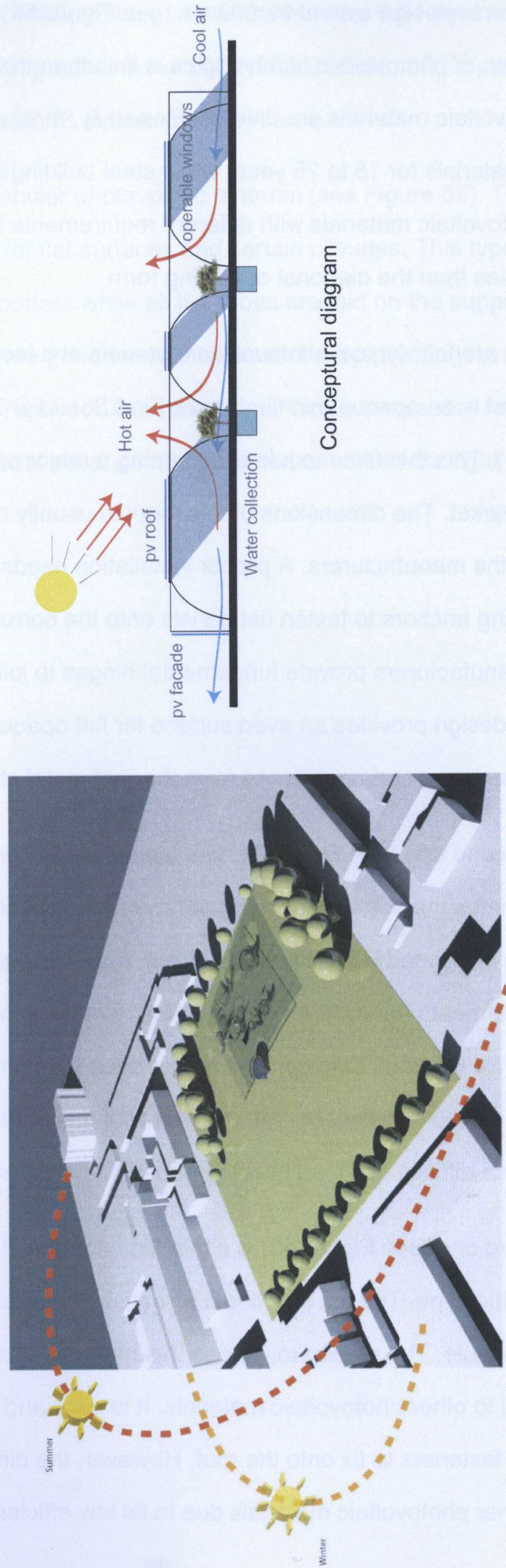
The idea to design a steel framework (see Figure 53) is driven by the facts that the average lifespan of photovoltaic technologies is less than that of the building and that the forms of photovoltaic materials are diverse. Generally, most manufacturers guarantee their photovoltaic materials for 15 to 25 years while steel buildings can last more than 50 years. For future photovoltaic materials with different requirements a cubic framework provides more possibilities than the diagonal or waving form.

There are four typical photovoltaic materials and technologies proposed in the project. The first is an opaque thin film panel, First Solar FS-270, $1200 \times 600 \times 6.8 \mathrm{~mm}, 70 \mathrm{~W}$ (see Figure 54). This thin film module is becoming a major player in the future of the photovoltaic market. The dimensions of this module usually range from 1000 to $2000 \mathrm{~mm}$ depending on the manufacturers. A proper installation needs extra structural supports like clips and framing anchors to fasten flat panels onto the corrugated metal sheet of the roof. In most cases manufacturers provide fundamental hinges to join adjacent flat panels for even surfaces. The design provides an even surface for flat opaque panels like FS-270. Panels have to be raised up a certain distance from the roof metal sheet for ventilation and drainage.

The second one (see Figure 54) is a typical mono-crystalline photovoltaic cell. This material dominates the photovoltaic market. The reason to choose this material is that when these cells are integrated into a flat glazing roof, many design opportunities exist for skylight and space underneath the roof. As the research reveals, considerable patterns of these cells are applicable for this roof. One concern is that once the corrugated metal sheet is replaced by this type of sealed translucent roof, the new roof has to take on a waterproofing function that will increase difficulties of maintaining photovoltaic panels.

The third one (see Figure 55) is a thin film, opaque, flexible sheet that is also an emergent product type. The flat roof can also satisfy the installation requirements of this photovoltaic module. The reason to choose this material is its considerably low installation cost compared to other photovoltaic materials. It is easy and quick to install and usually only requires small fasteners to fix onto the roof. However, the dimension of this material is large than that of other photovoltaic materials due to its low efficiency. For instance, SI-M2 288,
$300 \mathrm{Wp}$, from Solar Integrated is $5600 \mathrm{~mm}$ long and $900 \mathrm{~mm}$ wide, 5.04 square metres in area. The dimensions of poly-crystalline panels, Schott ASE-300-DGF/50, $300 \mathrm{Wp}$, are only $1892 \mathrm{~mm}$ long and $1283 \mathrm{~mm}$ wide, 2.43 square metres in area.

The last one is opaque tubular photovoltaic material (see Figure 55). The advantage of this material is its fine design for flat surfaces and certain climates. This type of material needs lightweight hook-like supporters while all the tubes are laid on the supporters. The gaps between tubular materials are good for ventilation and waterproofing. In addition, these materials are easily replaced or repaired. A bright roof surface is necessary for increase the performance of this tubular material because it is designed to absorb the light from reflection and diffusion. 

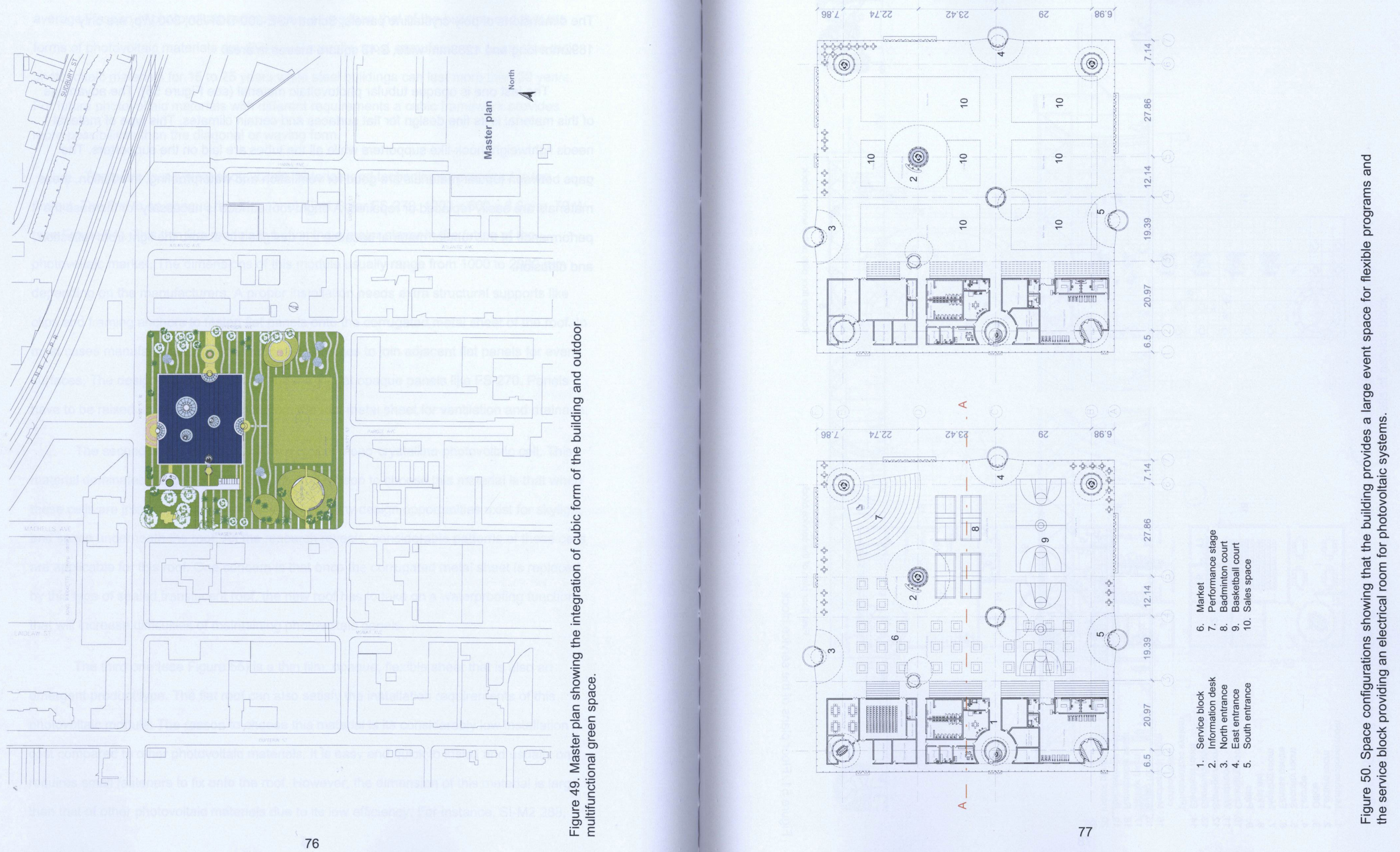

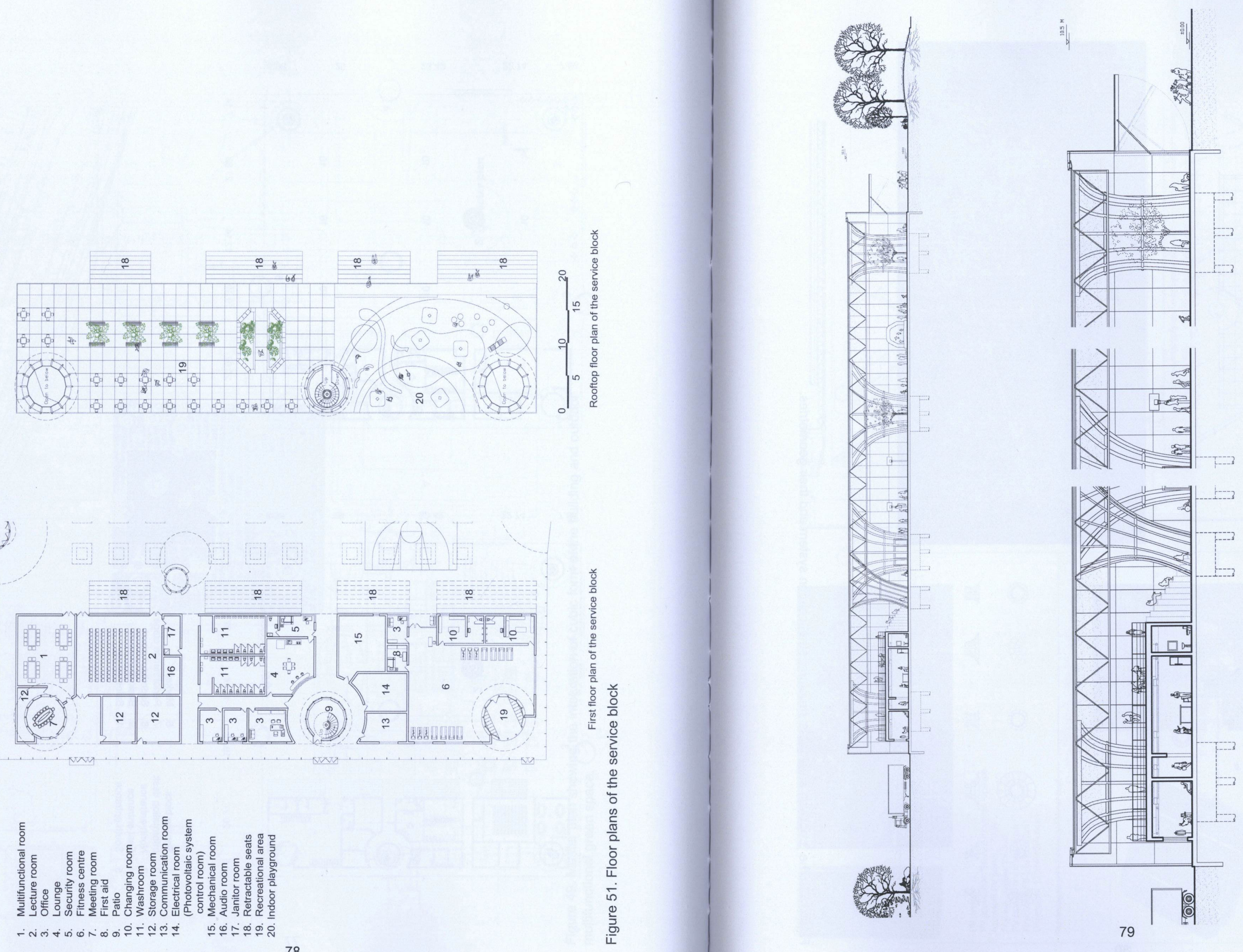
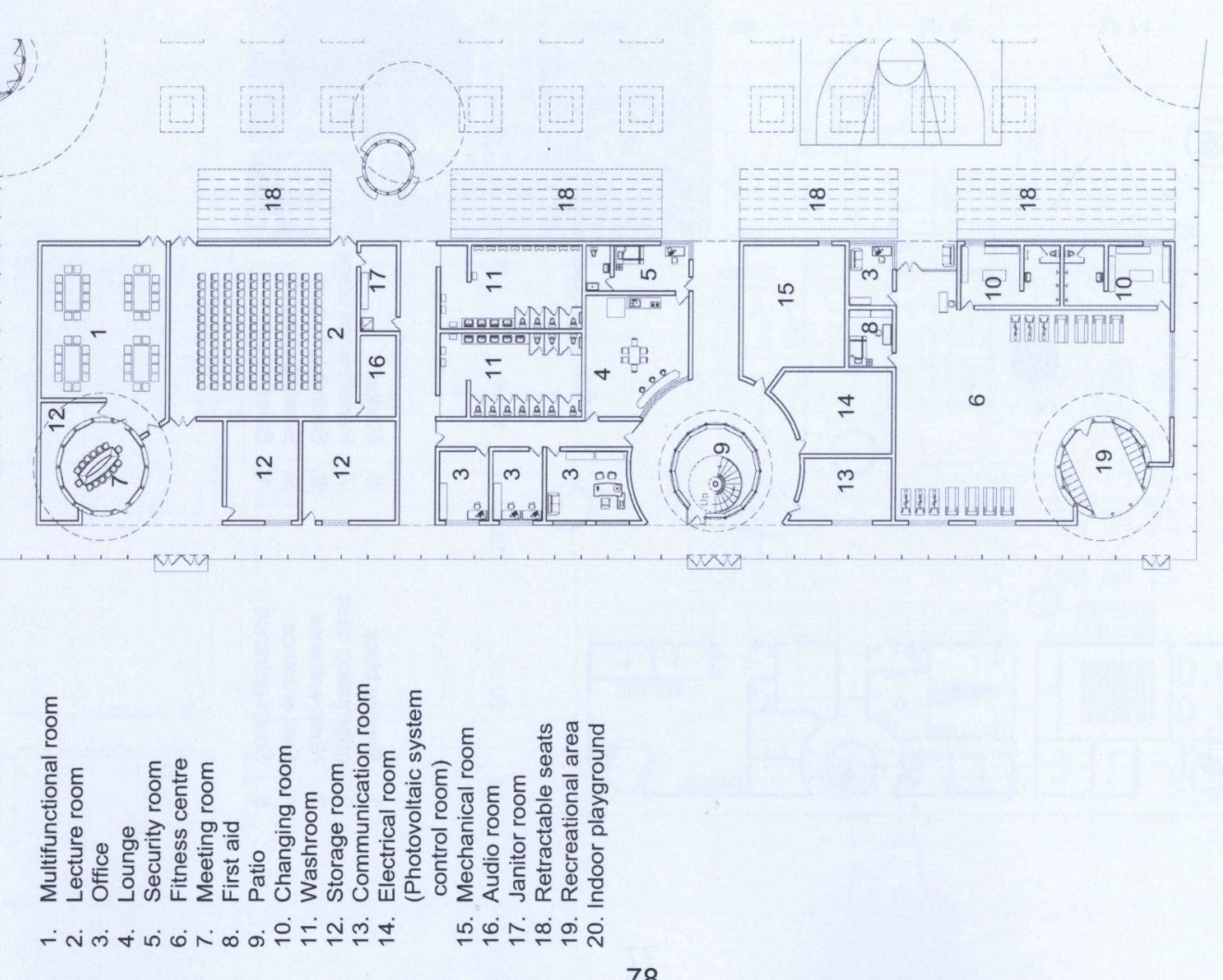

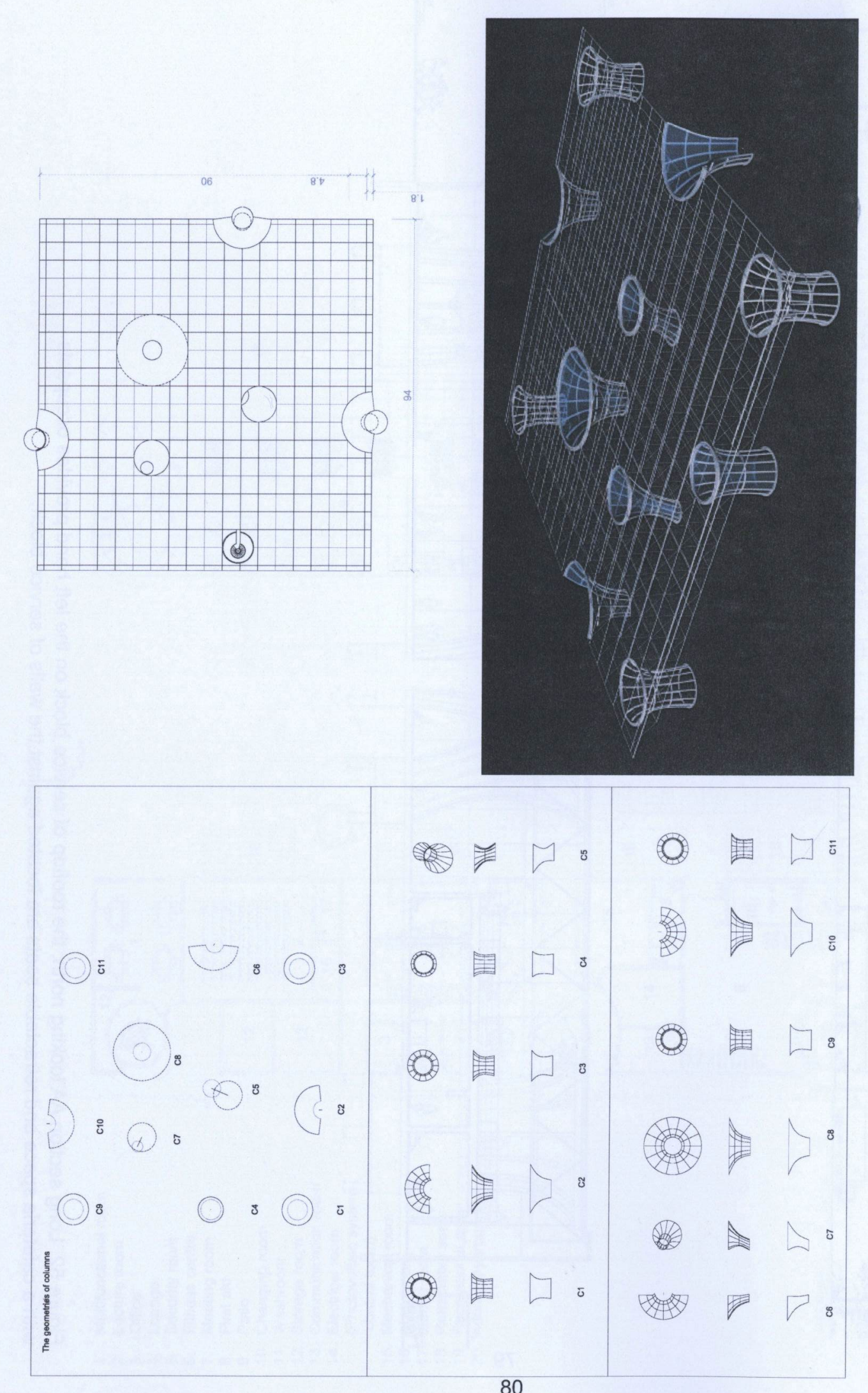
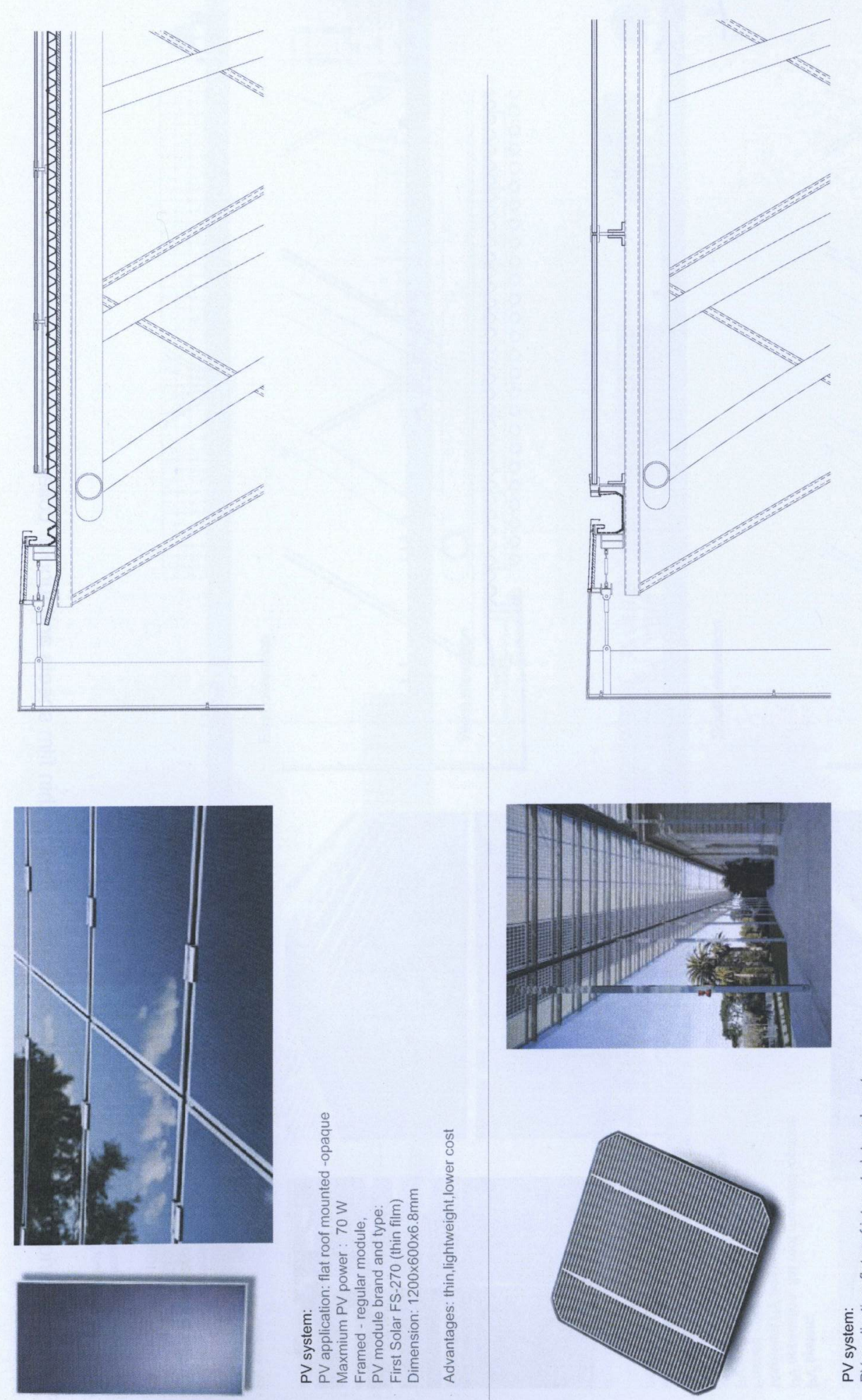

政

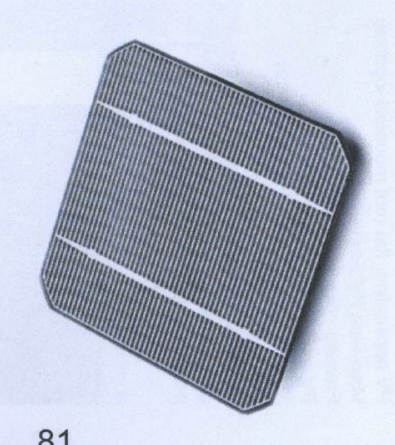



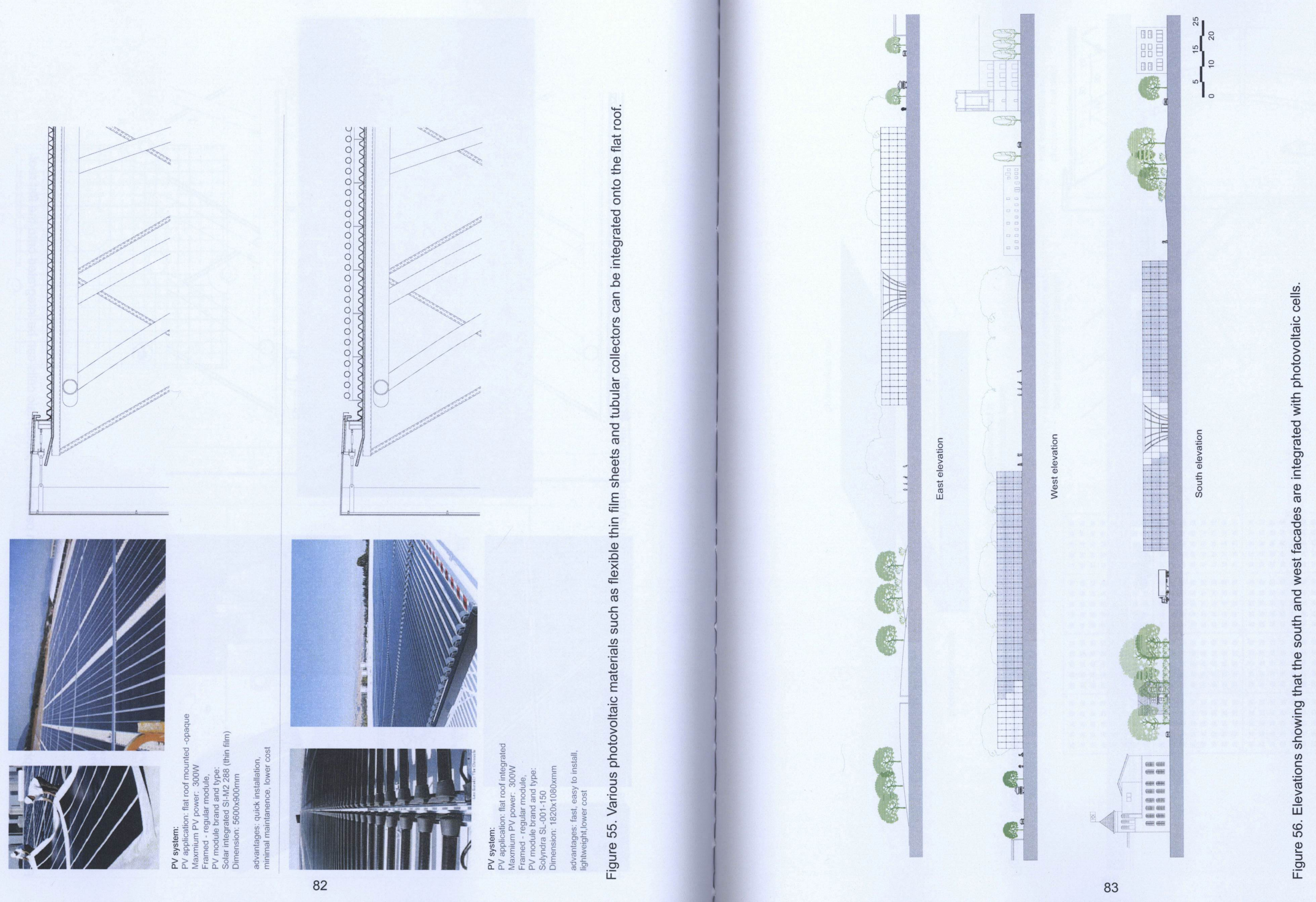

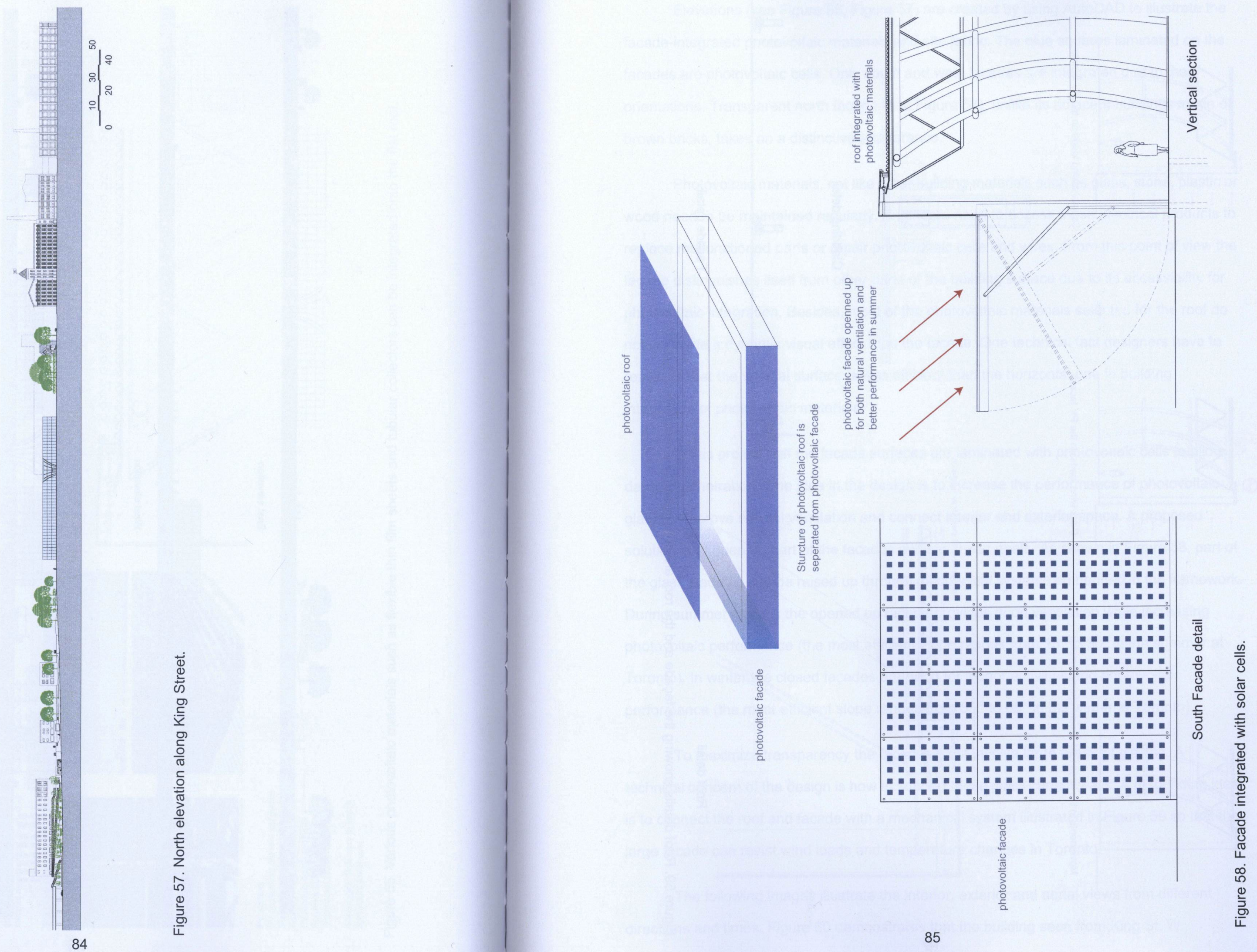

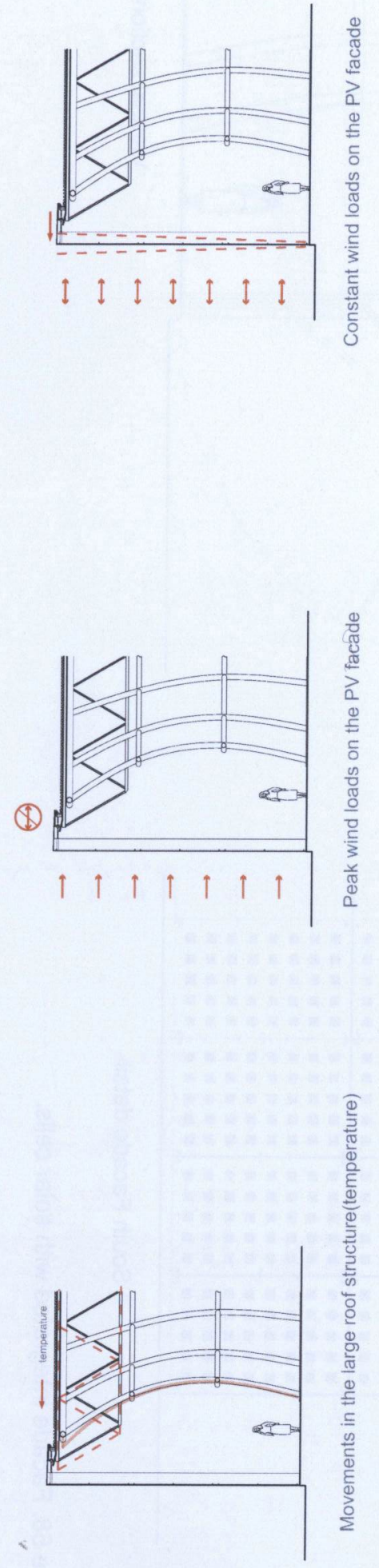

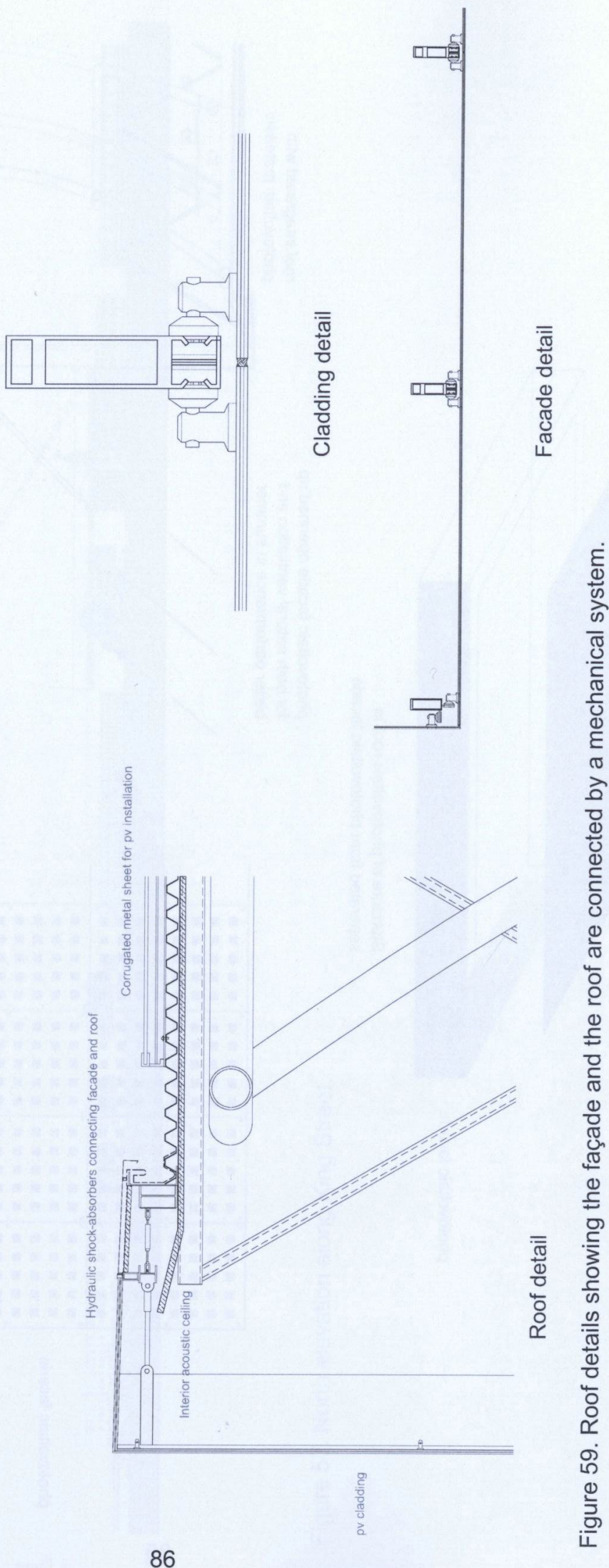

86
Elevations (see Figure 56, Figure 57) are created by using AutoCAD to illustrate the facade-integrated photovoltaic materials and site fabric. The blue squares laminated on the facades are photovoltaic cells. Only south and west facades are integrated due to their orientations. Transparent north facade (see Figure 57), unlike its adjacent buildings made of brown bricks, takes on a distinctive appearance.

Photovoltaic materials, not like other building materials such as glass, stone, plastic or wood need to be maintained regularly. Engineers need to access these electrical products to replace malfunctioned parts or repair photovoltaic cells and wires. From this point of view the façade distinguishes itself from other parts of the building surface due to its accessibility for photovoltaic integration. Besides, most of the photovoltaic materials selected for the roof do not generate a dynamic visual effect than the façade. One technical fact designers have to realize is that the vertical surface is less efficient than the horizontal one in building integration of photovoltaic materials.

In this project half the facade surfaces are laminated with photovoltaic cells to allow daylight penetration. One idea in the design is to increase the performance of photovoltaic glazing, improve natural ventilation and connect interior and exterior space. A proposed solution is to open up part of the facades achieve these goals. As shown in Figure 58, part of the glass cladding can be raised up through mechanical systems embedded in the framework. During summer months the opened up façade provides good ventilation while increasing photovoltaic performance (the most efficient slope ranges from $15^{\circ}$ to $30^{\circ}$ in the summer at Toronto). In winter the closed façades are good for indoor activities and photovoltaic performance (the most efficient slope ranges from $55^{\circ}$ to $65^{\circ}$ in the winter at Toronto)

To maximize transparency the facades must involve large areas of glazing. A technical concern of the design is how to support these glass curtain walls. A responding idea is to connect the roof and facade with a mechanical system illustrated in Figure 59 so that the large facade can resist wind loads and temperature changes in Toronto.

The following images illustrate the interior, exterior and aerial views from different directions and times. Figure 60 demonstrates that the building seen from King St. W. 
performs a transparent effect at night. In the service zone one of the ring-like steel columns contains a spiral stair for maintaining the photovoltaic roof and accessing the second floor of the service block. Figures 61 , Figure 62 and Figure 63 demonstrate that parts of the facades laminated with photovoltaic cells can be opened up to connect interior and exterior activities such as community markets. This design provides not only flexibility for space usage but an increase in performance of photovoltaic cells and natural ventilation for the building. Figure 64 illustrates that facades integrated with photovoltaic cells can be one visual component in architectural design. The roof, covered with corrugated metal sheets, provides opportunities for various photovoltaic technologies (see Figure 65).

\section{Project brief:}

Project location: Toronto, Ontario, Canada

Latitude: $43^{\circ} 38^{\prime} 20.20 " \mathrm{~N}$

Longitude: $79^{\circ} 25^{\prime} 22.87^{\prime \prime} \mathrm{W}$

Daily solar radiation: $1.0 \mathrm{Kw} / \mathrm{h} / \mathrm{m}^{2} / \mathrm{d}(\mathrm{Dec}$.) $6.0 \mathrm{Kw} / \mathrm{h} / \mathrm{m}^{2} / \mathrm{d}$ (June)

Wind speed: $3.3 \sim 4.8 \mathrm{~m} / \mathrm{s}$

Building Height:

$10.5 \mathrm{~m}$

Building dimension: 94 metres $\times 90$ metres

Building floor area: $8400 \mathrm{~m}^{2}$

Roof area: $\quad 7600 \mathrm{~m}^{2}$

Façade area: $\quad 560 \mathrm{~m}^{2}$

Façade PV area: $\quad 144 \mathrm{~m}^{2}$

Numbers of $P V$ panels: 4485

Numbers of PV cells: 2568(south façade) 2664 (west façade)
Service block height: 4 metres

Truss structural height: 3 metres

Electricity generation estimated annually:

1,070 Mwh (roof); 19Mwh(façade)

Proposed solar panels:

1. Sharp NT-185u1 $(1575 \times 826 \times 46$ $\mathrm{mm}), 185 \mathrm{Wp}$,

$14.22 \%$ efficiency

2. $Q$ cells mono-Si-Q6LM-1680

$(156 \mathrm{~mm} \times 156 \mathrm{~mm}) 4 \mathrm{Wp}$

$16.8 \%$ efficiency

$100 \%$ PV energy absorption rate

$72 \mathrm{~kW}$ inverter with $100 \%$ efficiency

$0 \%$ miscellaneous losses
Proposed structure: Steel truss system

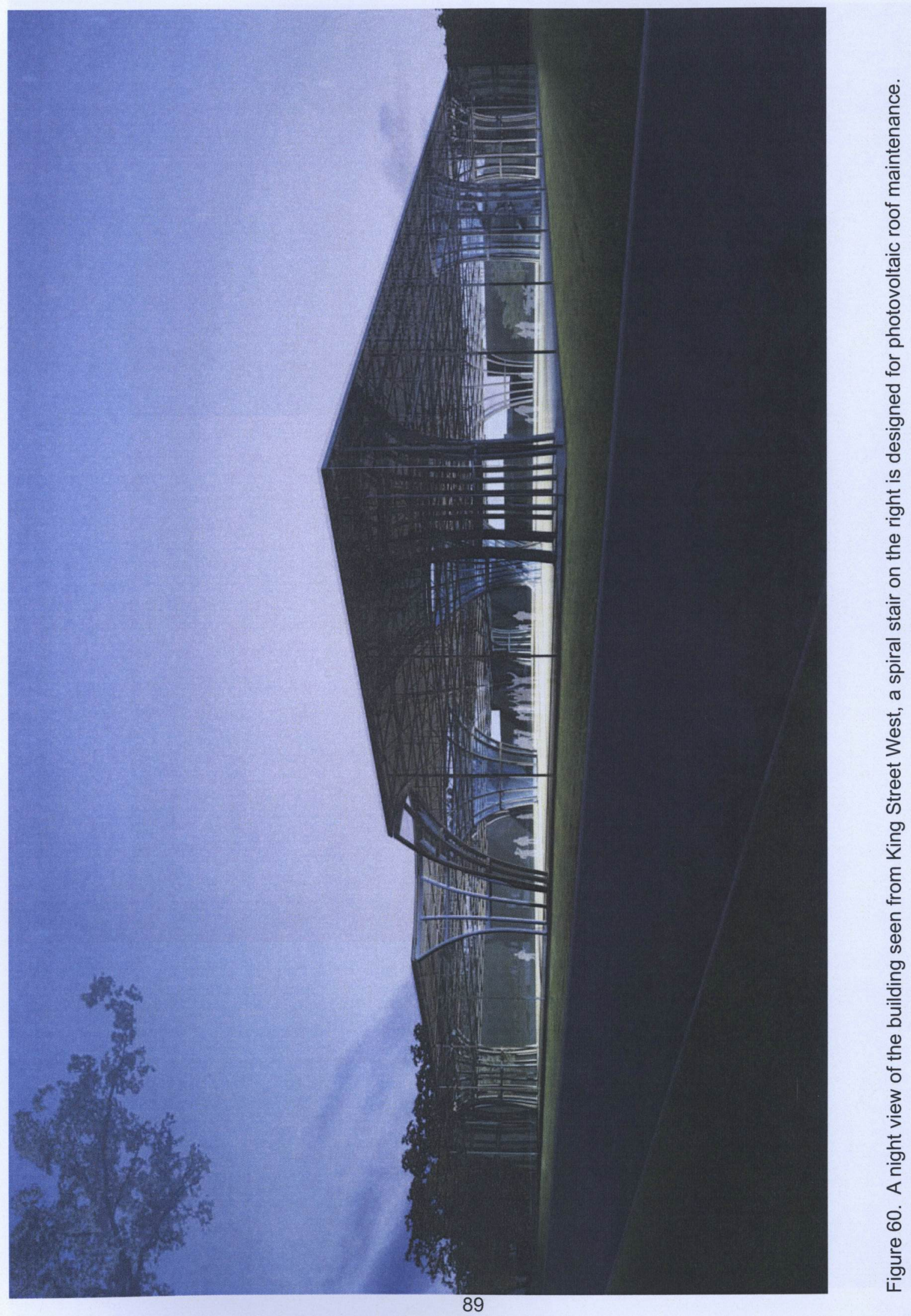



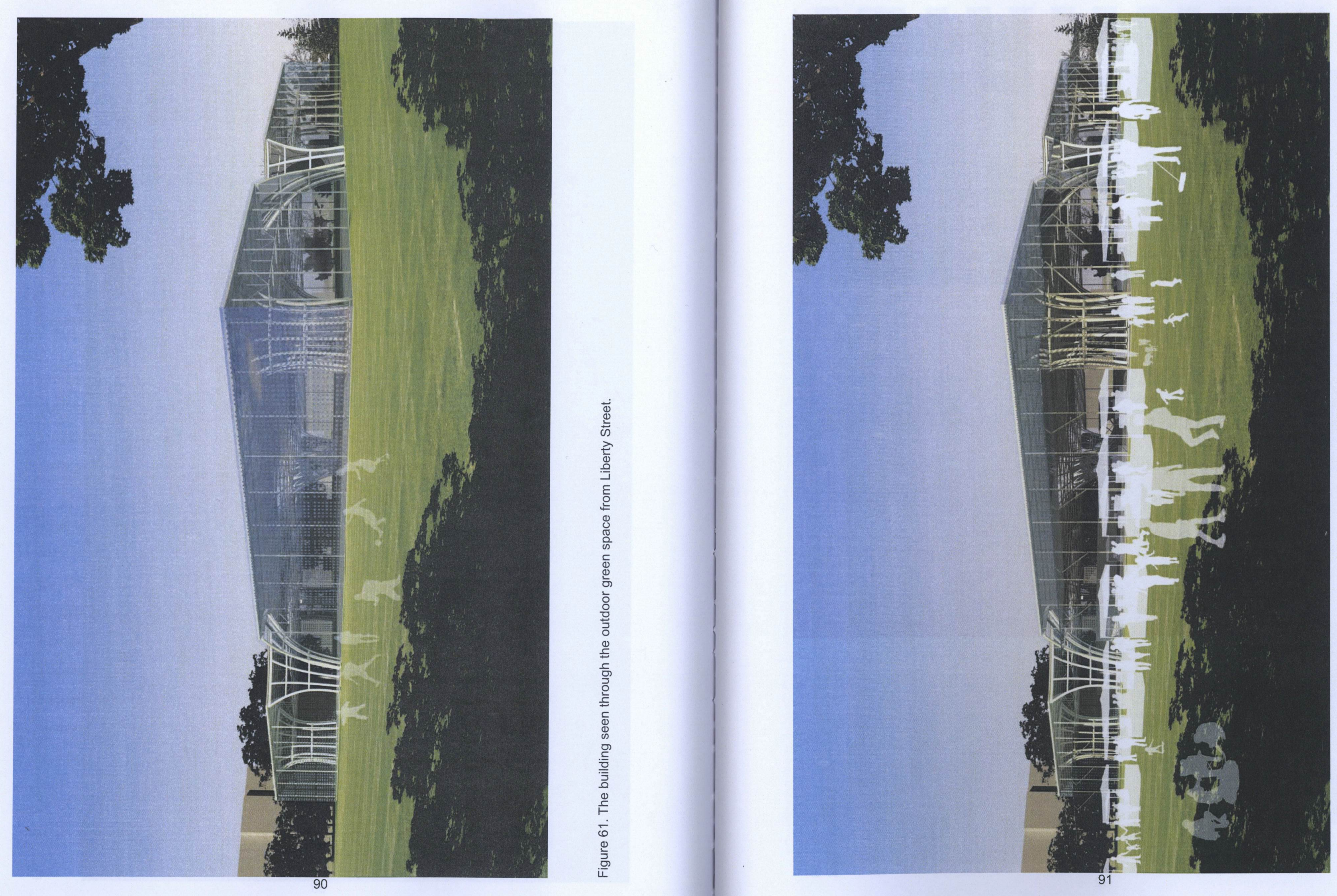


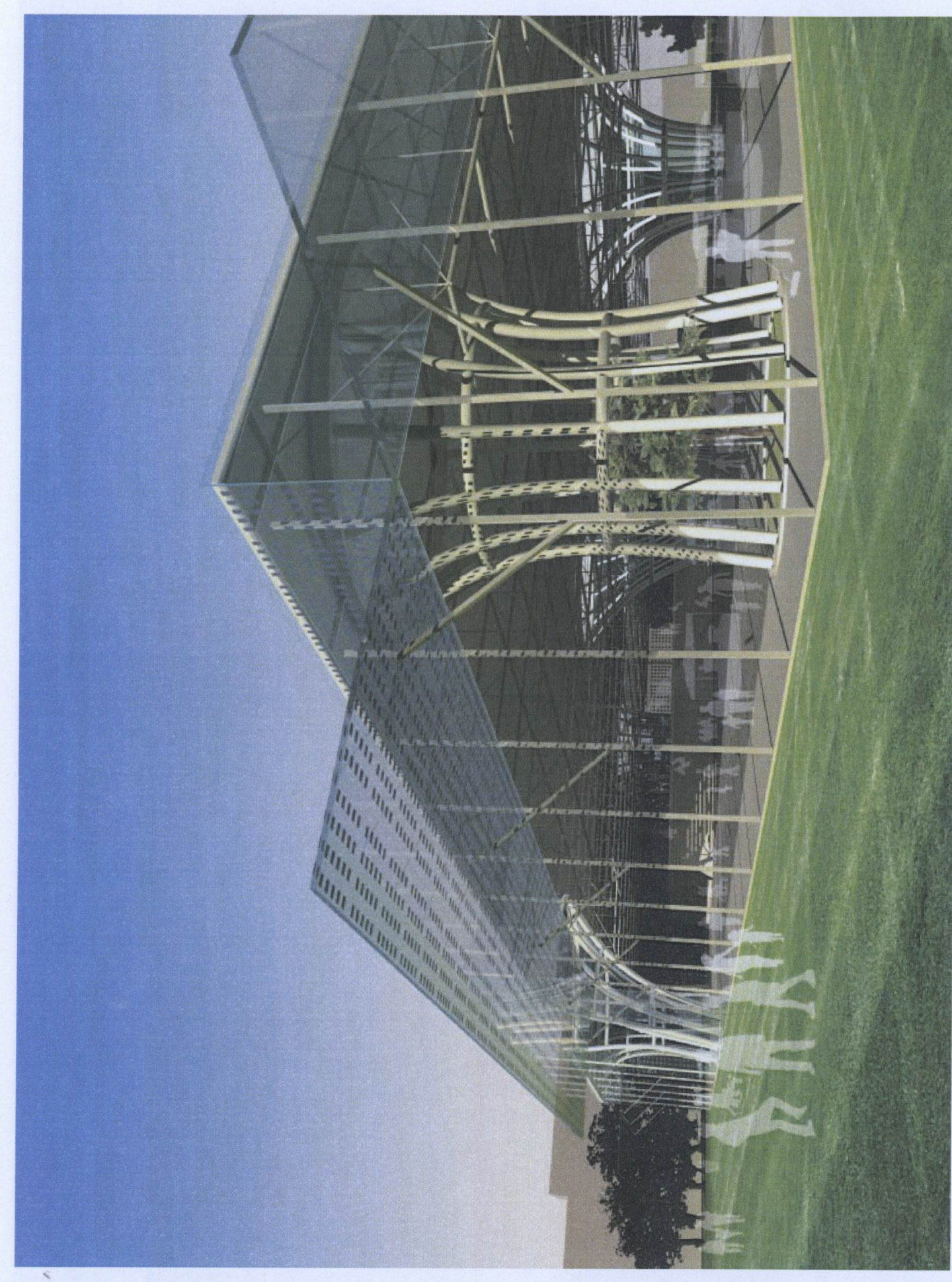

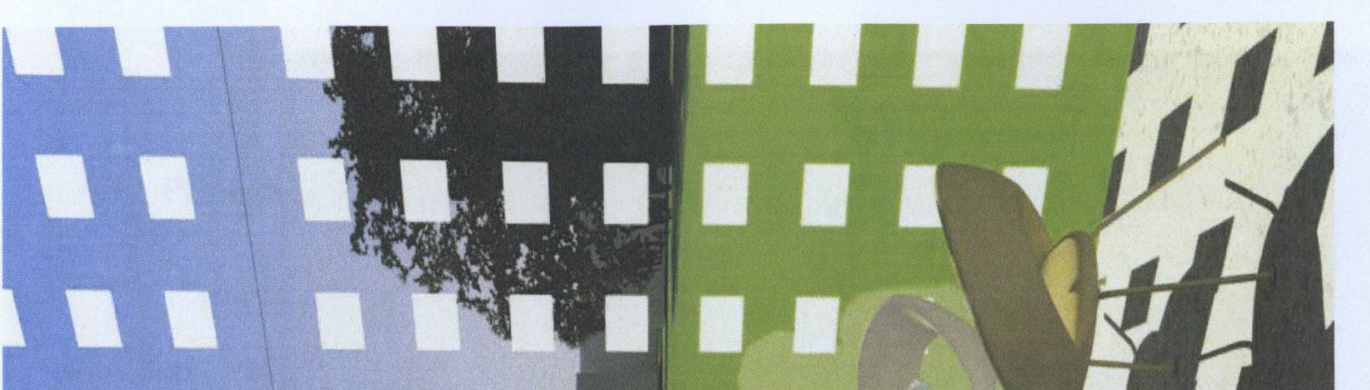
………

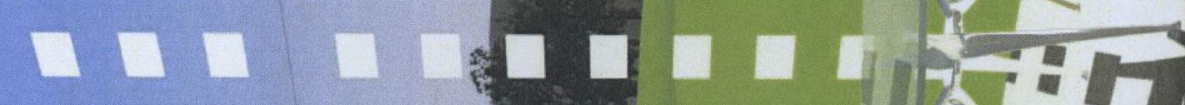

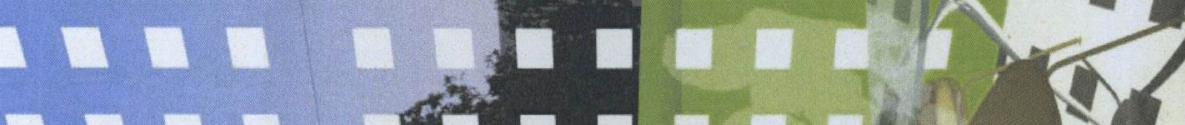

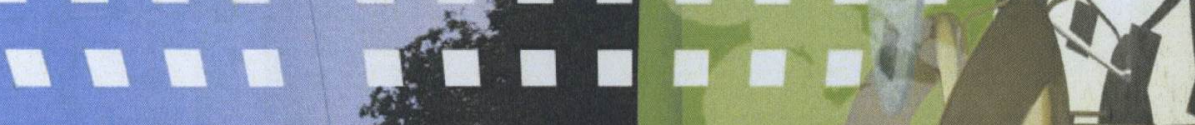
काषम

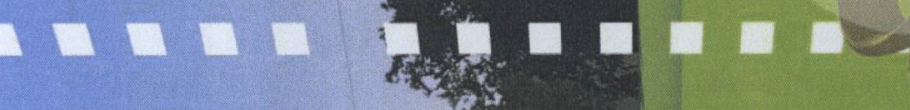

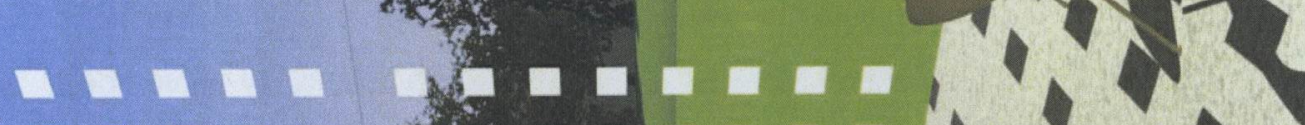

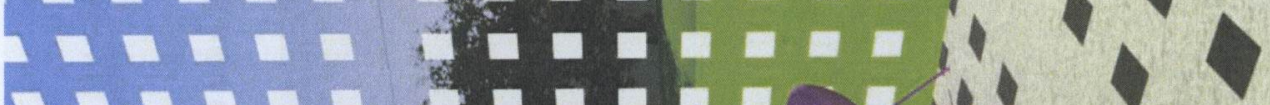

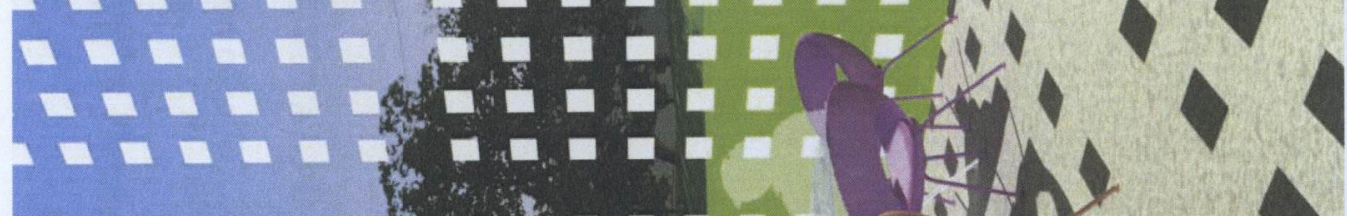

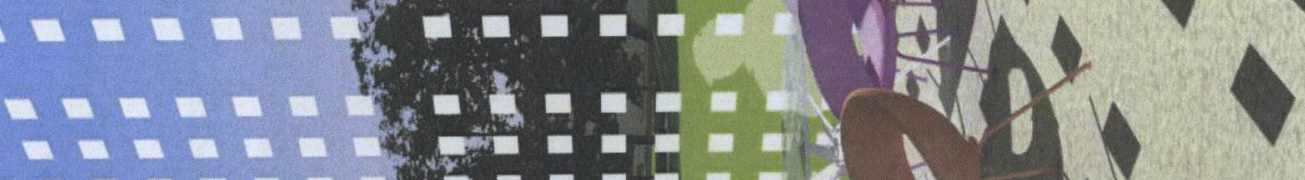

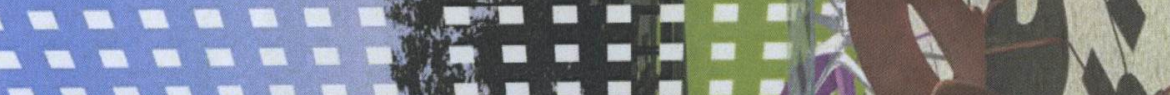

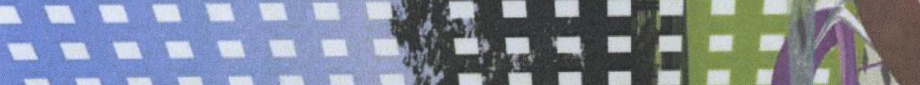

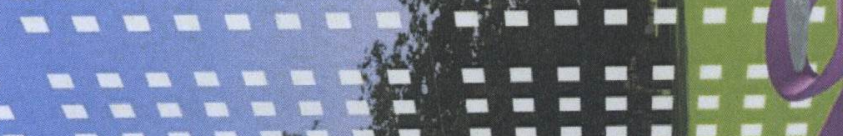

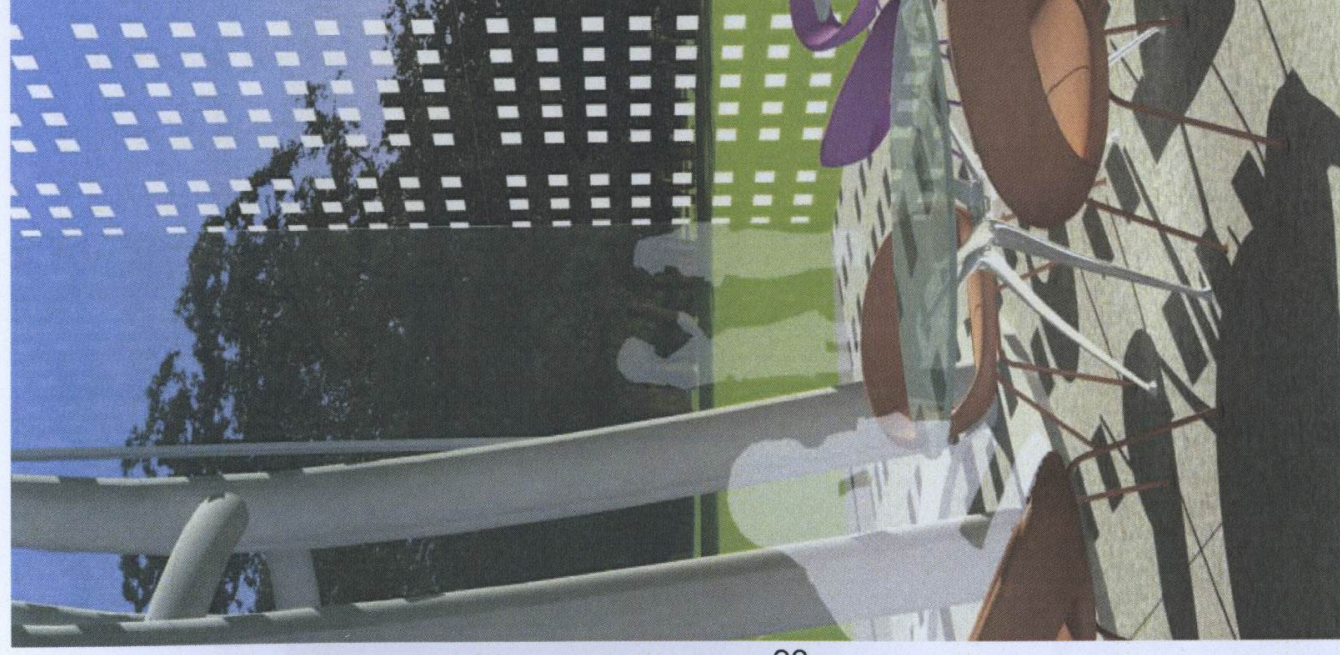




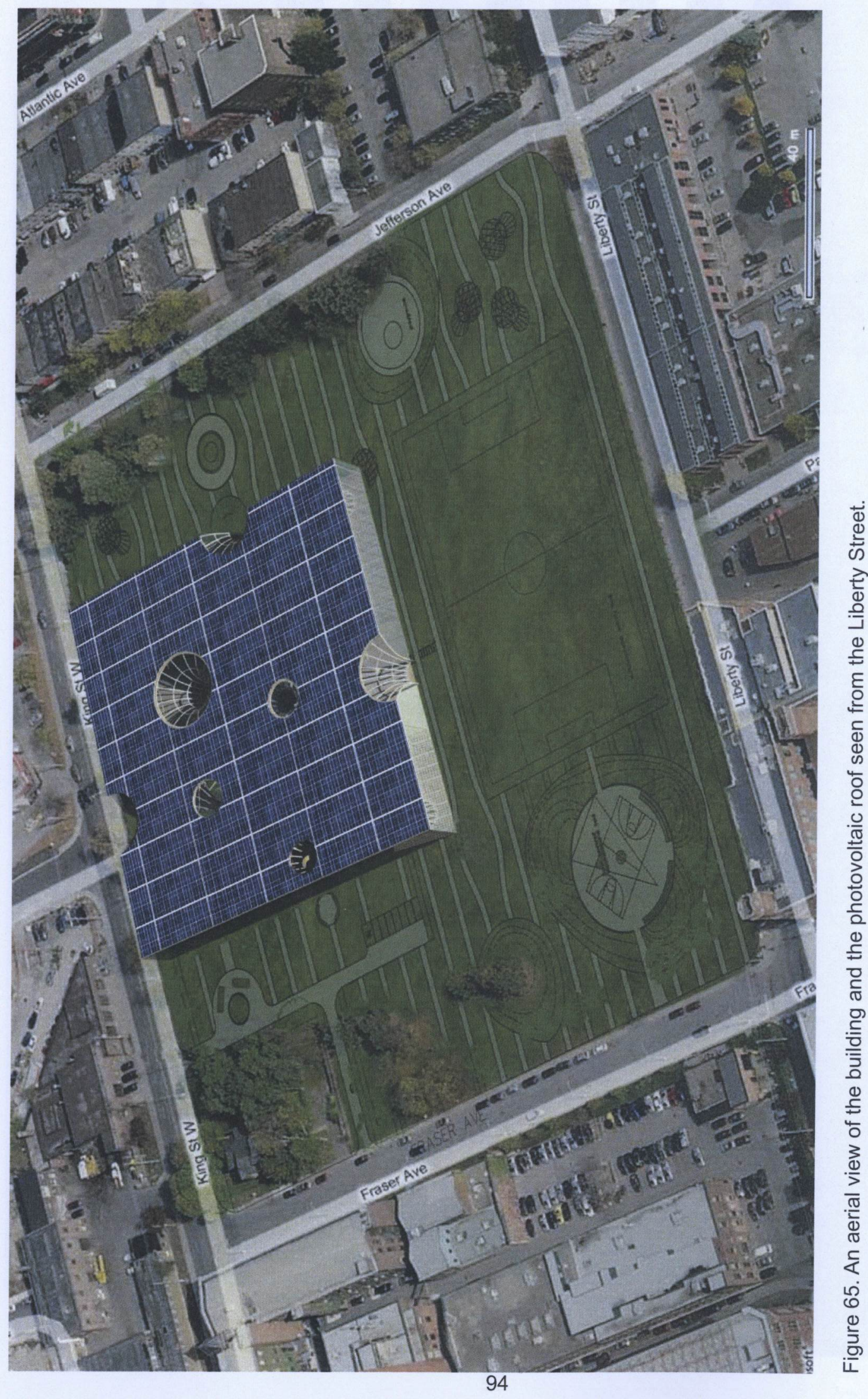

4.1 Principles for the building forms integrated with photovoltaic materials

The research and the design project revealed four general principles that influence the design of buildings integrated with photovoltaic materials. The principles discussed in this section are applicable to most photovoltaic integration in northern hemispheres. Generally, photovoltaic materials can be installed or integrated with various building surfaces including flat roofs, sloped roofs, free form roofs and exterior walls. The type of photovoltaic material is significant to the design process, affecting the form making, architectural ideas and detail design of photovoltaic integration.

For large scale photovoltaic integrations, accessibility, flexibility and separation from structure are critical in the design processes. These three criteria affect installation details and other design decisions. For small scale photovoltaic integration form making and building geometries vary. Understanding the general principles of photovoltaic integration helps to reduce the difficulties in the design process and achieve a successful architectural solution for photovoltaic components.

Principle 1: For small-scale buildings integrated with photovoltaic materials

Generally, buildings with simple functions, low energy consumption, simple structures and small floor areas are considered small-scale buildings. Based on this definition, many types of buildings fall in to this category, including houses, bus stations, and garages. Architects need to identify them during the conceptual design process.

Diversity of the building forms is one major feature in small-scale buildings. For photovoltaic integration of small-scale buildings, the construction cost of structure supporting free form is not as significant as that of large scale buildings. In addition, the negative influence of diagonal space can be easily offset by adjusting floor height or interior space. 
Solar modules installed on the roof are more efficient and economical than solar tiles. However additional racks of framework must be built to accommodate the solar modules. Efficiency and performance is reduced in the summer when solar tiles are used on the roof because there is no air convection.

If flat opaque photovoltaic materials are to be mounted on the roof as an additional layer without a waterproofing function, then the roof must be designed with complete functions, such as moisture protection, thermal insulation and noise protection. If a tilted circular roof integrated with photovoltaic materials is visible to the public, the margin between photovoltaic array and the roof edges produces a visual concern. Flexible thin film photovoltaic materials are usually not designed to take on as much static load as roofs do; therefore a supporting structure is needed if flexible thin film sheets are installed on the building roof.

If opaque photovoltaic panels replace conventional building façades, then insulation layers should be considered. This is especially important in colder climates. If translucent photovoltaic panels (amorphous panels, solar cells or other micro photovoltaic cells) replace one part of the building façade, then the built-form will take on a dark glaze-like appearance. Designers should select other building components to balance the appearance of photovoltaic materials.

Principle 2: For large-scale buildings integrated with photovoltaic materials

Building programs and functions take priority over photovoltaic materials to create building structures. It is important that the structure should be designed to accommodate the building programs first.

Separation between structure supporting photovoltaic materials and other building components will reduce the potential difficulties of integrating photovoltaic materials into building forms. This principle implies that design building components like porches, stands, canopies or other independent infrastructures that support photovoltaic materials is a priority.
In cold climates, an enclosed interior space provides occupants with more opportunities of activities than an open structure.

A steel structure is an important option for large scale photovoltaic integration where large spans are needed. The steel truss system, ranging from 20 metres to more than 100 metres, is an economical solution for large spaces. In some cases, timber can be also used. However, the short span of timber combined with fire safety requirements limit timber's application as a structural component.

A sealed roof surface with appropriate photovoltaic panels is preferable if waterproofing function has to be considered in the design. This may result in a thicker roof layering and higher construction cost because a sealed roof needs to bear dynamic and static loads. If an independent canopy is integrated with photovoltaic panels, the roof can be designed into a saw tooth roof to increase performance of photovoltaic panels. If a large-scale building roof is integrated with flat photovoltaic panels, better air convection will improve the performance of the materials in the winter.

If a large structural glazing is integrated with photovoltaic cells, a suitable glazing structure such as a truss system should be considered because the glass panes integrated with the photovoltaic modules are thicker than normal glazing façade. If the design objective is to achieve high performance of photovoltaic panels, then designing a semi-transparent photovoltaic façade will not achieve this goal because of its low efficiency. In addition, façade integration costs twice as much as roof integration

If it is difficult to transform a building form into a diagonal form or free form, then a cubic form with a flat roof may be an alternative. The structure of a flat roof is simpler as compared with other forms, which reduces the construction and electrical costs. If solar modules are designed with functions such as acoustic protection, thermo-protection and waterproofing, then the thickness of the modules must increase. 
Principle 3: Flexibility for a variety of solar technologies

Photovoltaic materials and technologies are advancing and architects should design an efficient framework that allows the integration of various photovoltaic materials.

Flexibility is built by roof surface angles, roof materials and photovoltaic materials. For angled surfaces, some flat photovoltaic materials are easily integrated; however, some tubular photovoltaic materials may not be easily mounted on an angled surface.

An exposed steel truss system is not as flexible as a flat roof covered with metal sheets or concrete slabs. Generally, customized solar panels are suitable for an exposed steel truss system. In addition, a truss system that is designed for one particular module type does not easily adapt to different module types.

The façade has the same limitations as the roof does. Once particular areas on the vertical surface are designated for selected photovoltaic materials, the possibility of replacing them with other modules with different dimensions is limited.

An enclosed flat roof can easily be installed with various solar modules.

\section{Principle 4: For facades integrated with photovoltaic cells}

Opaque photovoltaic cells can be laminated into double glazed panels to take on a semi-transparent appearance. The sandwich structure, its thickness usually ranging from 18 to $40 \mathrm{~mm}$, is heavier than single-layer glazed panels. If a sandwich glazed system is designed then a stable structural system must be carefully considered. When designing transparent facades, it is extremely important that the weight of the glazing be taken into account.

\subsection{Summary of research}

The primary goal of this thesis was to explore the relationship between building forms and photovoltaic systems. Through analyzing the interaction between a photovoltaic systems performance and building forms, mostly in small scale residential and commercial buildings, it discusses the implications for the creative architectural integration of photovoltaic materials.

The intent was to provide recommendations for decision making in the primary design phrase of photovoltaic integration. The principles are applied to the design of the Lamport Stadium recreational facility -- a proposed project located in Toronto. The proposed design expresses an idea to transform public facilities into solar electricity generators not only technically but also aesthetically.

In the decision making, processes of design, availability, accessibility and perceptibility of building surfaces for photovoltaic materials were significant. The features of the proposed design also demonstrate that considerable design opportunities exist even though rigid building forms have been determined through rational analysis.

The thesis project demonstrates that architectural integration of photovoltaic materials can achieve unity, harmony and creativity. A successful architectural integration of photovoltaic materials relies on comprehending diverse photovoltaic materiality and technologies as well as the interaction between materials and building forms.

\subsection{Limitations of the study}

Because of limited information collected and analyzed in this thesis, only majo photovoltaic materials and technologies such as flat photovoltaic panel, tubular thin film collectors and flexible thin film panels are included. New photovoltaic technologies like semi-spherical materials, due to their experimental stages, are not included in the research. 
materials has not been explored thoroughly. Whether building types influence building

surfaces applicable to photovoltaic materials remains unclear.

The geographical locations for the case studies and the design project are limited to the countries in northern hemisphere such as Austria, Canada, China, Germany, Japan and U.S. Therefore the implications and principles applied to the proposed design may be not suitable for equatorial areas and the southern hemisphere.

\section{Appendix A}

Table 1

Dimensions and architectural properties of selected solar panels

\begin{tabular}{|c|c|c|c|c|c|c|c|}
\hline \multirow{3}{*}{$\begin{array}{l}\text { Manufactures } \\
\text { BP solar }\end{array}$} & \multirow[t]{2}{*}{ Modules } & \multirow[t]{2}{*}{ Cell Tech } & \multirow{2}{*}{$\begin{array}{l}\text { Capacity } \\
\text { Watt }\end{array}$} & \multirow{2}{*}{$\begin{array}{l}\text { Length } \\
\mathrm{mm}\end{array}$} & $\frac{\text { Width }}{\mathrm{mm}}$ & \multicolumn{2}{|c|}{ Thickness Weight } \\
\hline & & & & & $\mathrm{mm}$ & $\mathrm{k}$ & \\
\hline & $s \times 3200 B$ & Multicrystalline & 200 & 1680 & 837 & 50 & 17.2 \\
\hline \multirow{14}{*}{ wmw.bp.com } & sx3200w & Multicystalline & 200 & 1680 & 837 & 50 & 17.2 \\
\hline & sX3195N & Multicystalline & 195 & 1680 & 837 & 50 & 17.2 \\
\hline & s×3195B & Multicystalline & 195 & 1680 & 837 & 50 & 17.2 \\
\hline & $s \times 31900 \mathrm{~B}$ & Multicystalline & 190 & 1680 & 837 & 50 & 17.2 \\
\hline & sx3190w & Multicystalline & 190 & 1680 & 837 & 50 & 17.2 \\
\hline & BP4175B & Monocrystalline & 175 & 1593 & 790 & 50 & 15.4 \\
\hline & BP41751 & Monocrystalline & 175 & 1587 & 828.4 & 50 & 15.4 \\
\hline & BP4175N & Monocrystalline & 175 & 1593 & 790 & 50 & 15.4 \\
\hline & BP1751 & Polycrystalline & 175 & 1587 & 828.4 & 50 & 15.4 \\
\hline & BP175B & Polycrystalline & 175 & 1593 & 790 & 50 & 15.4 \\
\hline & BPSX $160 \mathrm{~B}$ & Polycrystalline & 160 & 1593 & 790 & 50 & 15.4 \\
\hline & $s \times 3140 J$ & Polycystalline & 140 & 1510 & 674 & 50 & 12 \\
\hline & BP $3125 \mathrm{~J}$ & Polycrystalline & 125 & 1510 & 674 & 50 & 12.1 \\
\hline & $\mathrm{s} \times 380 \mathrm{~J}$ & Polycrystalline & 125 & 1209 & 537 & 50 & 7.7 \\
\hline \multirow[t]{7}{*}{ Canadian Solar } & All-Black CS5A & Mono & 160/170/180 & 1595 & 801 & 40 & 15.5 \\
\hline & CS5P & Mono & $\begin{array}{r}200 / 12101 / 220 / \\
230 / 240\end{array}$ & 1602 & 1061 & 40 & \\
\hline & CSGA & Silicon & $\begin{array}{l}150 / 160 / 170 \\
\end{array}$ & 1324 & 982 & 40 & 16 \\
\hline & CS6P & Grade Silicon & $\begin{aligned} 170 / 1800 \\
200\end{aligned}$ & 1638 & 982 & 40 & 18.5 \\
\hline & CS6P & Poly(Mono) & $\begin{array}{r}2000121012201 \\
230 / 240\end{array}$ & $\quad 1638$ & 982 & 40 & 18.5 \\
\hline & & $\begin{array}{l}\text { Crystalline(Mono } \\
\text { or poly (Mon }\end{array}$ & & $\begin{array}{r}100 \times 100(\min ) \\
2000 \times 3000(\max \end{array}$ & & & \\
\hline & BIPV & $125 / 156 \mathrm{~mm})$ & 55-115 & & & & $5 \mathrm{~kg} / \mathrm{sqm}$ \\
\hline \multirow[t]{8}{*}{ Centennial Solar } & BIPV & $\begin{array}{l}\text { Thin } \\
\text { Film(transparent) }\end{array}$ & 96 & 1204 & 2004 & 17 & 105 \\
\hline & & $\begin{array}{l}\text { Thin } \\
\text { Film(transparent) }\end{array}$ & 96 & 1184 & & 34 & 112 \\
\hline & OPAK-1-L & Thin Film(opaque) & 29 & 1027 & 627 & 17 & 27 \\
\hline & THRU-1-L & Film(transparent) & 25 & 1027 & 627 & 17 & 27 \\
\hline & ITHRRU-1-1-O & Filin(transparent) & & 1007 & 607 & $32 / 34$ & $24 / 29$ \\
\hline & $\begin{array}{l}\text { CS1818/190/200/ } \\
211 / 201 / 230\end{array}$ & Polycrystalline & $\begin{array}{l}180 / 1900 / 200 / \\
210 / 202 / 230\end{array}$ & 1647 & 991 & 46 & 22 \\
\hline & $\begin{array}{l}\text { CS1115/120/125/ } \\
1301 / 53 / 40\end{array}$ & & $\begin{array}{l}115 / 120 / 125 / \\
130 / 135 / 41\end{array}$ & & & 35 & 13 \\
\hline & $\begin{array}{l}\text { CS4OT } \\
\text { CST }\end{array}$ & Thin film(opaque) & 40 & 1005 & 605 & 34 & 6.3 \\
\hline \multirow{2}{*}{$\begin{array}{l}\text { First Solar } \\
\text { http://ww. firstsolar.com/ }\end{array}$} & FS260/262/265/ & & 60/62.5/65/6 & & & & \\
\hline & & Thin film & $\begin{array}{l}7.5 / 70772.57 / 7 \\
5 / 77.5 \\
\end{array}$ & 1200 & 600 & 6.8 & 12 \\
\hline \multicolumn{3}{|l|}{ GE http://gepower.com/ } & 60/200 & 1507/1485 & $446 / 981$ & $52 / 35$ & $18 / 39$ \\
\hline \multirow{3}{*}{$\begin{array}{l}\text { Isofoton } \\
\text { http://www.isofoton.com/ }\end{array}$} & $\mid \mathrm{S}-160 / 165 / 17$ & 7 isi Monocrystall & $65 / 170 / 175$ & 1600 & 790 & 40 & 14.4 \\
\hline & & & 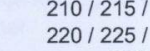 & & & & \\
\hline & $\mid \mathrm{S}-210 / 215 / 22$ & 21: i Monocrystalline & 230 & 1600 & 1047 & 40 & 18.5 \\
\hline
\end{tabular}




\begin{tabular}{|c|c|c|c|c|c|c|c|}
\hline & ISF-205/2 & 2 si Monocrystalline & $\begin{array}{r}205 / 210 / \\
215 / 220 \\
\end{array}$ & 1667 & 994 & 40 & 18.8 \\
\hline $\begin{array}{l}\text { Kyocera } \\
\text { hitt:///www.kyocerasolar.co } \\
\mathrm{m} /\end{array}$ & ${ }_{0}^{\mathrm{KCCKD}}$ & Multicystalline & $\begin{array}{l}401501 / 55 / 85 / \\
130 / 1351801 \\
2055 / 210\end{array}$ & $\begin{array}{l}526 / 640 / 752 / 10 \\
00 / 142211105111 \\
501 / 1501 / 1501\end{array}$ & 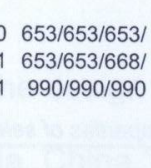 & 35.6 & \\
\hline Q-Cells & $\begin{array}{l}\text { CX 35-65 } \\
\text { SN2 } \\
\text { SL1 } \\
\text { BIPV }\end{array}$ & $\begin{array}{l}\text { Thin film } \\
\text { Micromorph thin filn } \\
\text { CIGS thin film } \\
\text { Mono/Multicrystallin }\end{array}$ & $\begin{array}{r}35-60 \\
125-145 \\
60-85 \\
3.44 \\
\end{array}$ & $\begin{array}{r}1200 \\
1684 \\
1190 \\
156 \\
\end{array}$ & $\begin{array}{r}600 \\
1056 \\
630 \\
156\end{array}$ & $\begin{array}{l}6.8 \\
8.4 \\
7.4\end{array}$ & $\begin{array}{l}12 \\
32 \\
13.2\end{array}$ \\
\hline
\end{tabular}

Note. The data in this table are collected from some manufacturers' websites. The Selection of photovottaic

chart. Only photovoltaic products for $U S S$ and Canada regions are chosen if the manuffacturers have variou

products for different regions.
Table 2

Photovoltaic Applications of Different Building Types

\begin{tabular}{|c|c|c|c|c|c|c|c|}
\hline \multicolumn{2}{|c|}{ Building types } & \multirow{2}{*}{$\begin{array}{c}\begin{array}{c}\text { Envelope suitable for } \\
\text { integration }\end{array} \\
\text { Windows, walls, roofs }\end{array}$} & \multirow{2}{*}{$\begin{array}{c}\text { Photovoltaic } \\
\text { Application }\end{array}$} & \multirow{2}{*}{$\begin{array}{c}\text { Name of project } \\
\begin{array}{c}\text { Wilmersdorfer } \\
\text { Straße }\end{array}\end{array}$} & \multirow{2}{*}{$\begin{array}{l}\text { Year } \\
2001\end{array}$} & \multirow{2}{*}{$\begin{array}{l}\text { Country } \\
\text { Germany }\end{array}$} & \multirow{2}{*}{ 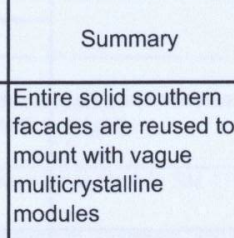 } \\
\hline & Apartments & & & & & & \\
\hline & Houses & Windows, walls, roofs & \begin{tabular}{|l} 
Inclined roof \\
integrated
\end{tabular} & $\begin{array}{l}\text { Villa Garten } \\
\text { Shin-Matsudo }\end{array}$ & 1999 & Japan & $\begin{array}{l}\text { Roofs have major } \\
\text { potentials for } \\
\text { photovoltaic } \\
\text { integration. }\end{array}$ \\
\hline \multirow[t]{3}{*}{$\begin{array}{l}\text { Commerical } \\
\text { buildings }\end{array}$} & Hotels & Windows, walls, roofs & $\begin{array}{l}\text { Facade integratec } \\
\text { in fixed } \\
\text { sunscreens }\end{array}$ & $\begin{array}{l}\text { Sun screen } \\
\text { Leeuwenhorst } \\
\text { Congres } \\
\text { Centrum }\end{array}$ & 1998 & Netherlands & $\begin{array}{l}\text { Conference hotel is a } \\
\text { multi-story building. } \\
\text { ldeas of photovoltaic } \\
\text { integraion seems to be } \\
\text { difficultly used in } \\
\text { hotles. }\end{array}$ \\
\hline & Shops & Windows, walls, roofs & \begin{tabular}{|l} 
Flat roof- \\
mounted \& ballast \\
fixing \\
Incined roof- \\
transparent roof
\end{tabular} & \begin{tabular}{|l|} 
"Madrid-2 La \\
Vaguada" \\
Commercial and \\
leisure Center
\end{tabular} & 2007 & Spain & $\begin{array}{l}\text { Roofs have major } \\
\text { potentials for } \\
\text { photovoltaic } \\
\text { integration. }\end{array}$ \\
\hline & Offices & Windows, walls, roofs & $\begin{array}{l}\text { Façade- } \\
\text { integrated in fixed } \\
\text { sunscreens, } \\
\text { Facade- } \\
\text { transparent PV } \\
\text { facade, } \\
\text { Facagade- } \\
\text { integrated other, } \\
\text { Inclined roof- } \\
\text { transparent roof }\end{array}$ & $\begin{array}{l}\text { |sofoton } \\
\text { Headquarters }\end{array}$ & 2005 & Spain & $\begin{array}{l}\text { Great potentials for } \\
\text { phhotovoltaic } \\
\text { integration. Semi- } \\
\text { transparant and oquue } \\
\text { materials can all be } \\
\text { ussed in silimar } \\
\text { projects. }\end{array}$ \\
\hline Transportation & \begin{tabular}{|l} 
Bus \\
Stations
\end{tabular} & roof & Roof integrated & \begin{tabular}{|l} 
Vauxhall Cross \\
Transport \\
Interchange
\end{tabular} & 2004 & UK & $\begin{array}{l}\text { Opportunities for form- } \\
\text { making and } \\
\text { photoloftaic } \\
\text { integration in } \\
\text { transportation projects }\end{array}$ \\
\hline \multirow[b]{2}{*}{$\begin{array}{l}\text { Institutional } \\
\text { buildings }\end{array}$} & $\begin{array}{l}\text { Research } \\
\text { facilities }\end{array}$ & Windows, walls, roofs & Façade integratec & $\begin{array}{l}\text { The OpTIC } \\
\text { Centre }\end{array}$ & 2004 & UK & $\begin{array}{l}\text { Particular } \\
\text { requirements on } \\
\text { interior daylight and } \\
\text { ventilation provide } \\
\text { opportunties for } \\
\text { facadd and roof } \\
\text { integration }\end{array}$ \\
\hline & $\begin{array}{l}\text { Colleges/u } \\
\text { niversities }\end{array}$ & Windows, walls, roofs & $\begin{array}{l}\text { Roof integrated, } \\
\text { Façadeintegrated } \\
\text { other }\end{array}$ & 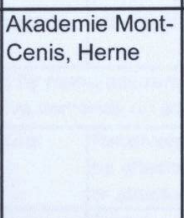 & 1999 & Germany & $\begin{array}{l}\text { Multifinctional center, } \\
\text { the seperartion of of } \\
\text { building kkins and } \\
\text { functional space make } \\
\text { photovotallic } \\
\text { integration and form- } \\
\text { making easier. }\end{array}$ \\
\hline
\end{tabular}




\begin{tabular}{|c|c|c|c|c|c|c|c|}
\hline & Schools & Windows, walls, roofs & Roof integrated & $\begin{array}{l}\text { Morschwiller } \\
\text { School }\end{array}$ & 2005 & France & 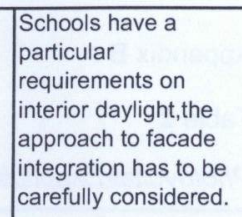 \\
\hline & Libraries & Windows, walls, roofs & $\begin{array}{l}\text { Facade integratec } \\
\text { in movable } \\
\text { sunscreen }\end{array}$ & $\begin{array}{l}\text { Leicester } \\
\text { University } \\
\text { Library }\end{array}$ & 2007 & UKK & \begin{tabular}{|l} 
Interior daylight qualitit \\
is one major concern \\
when the facade in is \\
integrated with \\
photovoltaics
\end{tabular} \\
\hline \multirow{3}{*}{ Public buildings } & Museums & Walls, roofs & $\begin{array}{l}\text { Façade mounted, } \\
\text { Flat roof mounted } \\
\& \text { mechanical } \\
\text { fixing }\end{array}$ & $\begin{array}{l}\text { The Museum of } \\
\text { Science \& } \\
\text { Technology in } \\
\text { Malmö }\end{array}$ & 2006 & Sweden & \begin{tabular}{|l} 
Roofs and facades alll \\
have mamojpotentials \\
tor photovottaic \\
integration.
\end{tabular} \\
\hline & Hospitals & Windows, walls, roofs & $\begin{array}{l}\text { Façade integratec } \\
\text { in fixed } \\
\text { sunscreens }\end{array}$ & $\begin{array}{l}\text { Sanitary } \\
\text { complex of the } \\
\text { Alzzeimer } \\
\text { Project }\end{array}$ & 2007 & Spain & \begin{tabular}{|l} 
Interior daylight quality \\
is one major concern \\
when the facade is \\
integrated wite \\
photovoltaics
\end{tabular} \\
\hline & Stadiums & Windows, walls, roofs & $\begin{array}{l}\text { Façade integrated } \\
\text { in movable } \\
\text { sunscreens }\end{array}$ & EWE Arena & 2006 & Germany & $\begin{array}{l}\text { Circular facade was } \\
\text { used to install a two } \\
\text { dimentitinal tracking } \\
\text { system }\end{array}$ \\
\hline Religious & Churches & Walls, roofs & $\begin{array}{l}\text { Inclined roof } \\
\text { integrated }\end{array}$ & Carlow Church* & 2001 & Germany & $\begin{array}{l}\text { The size and color of } \\
\text { photovoltaic modules } \\
\text { have to be adjusted to } \\
\text { suit sensitive } \\
\text { heritages. }\end{array}$ \\
\hline \begin{tabular}{|l} 
Insudustrial \\
buildings
\end{tabular} & factories & Windows, walls, roofs & Façade integrated & $\begin{array}{l}\text { Kyocera Mita } \\
\text { Hirakata factory }\end{array}$ & 2006 & Japan & $\begin{array}{l}\text { Solar modules are } \\
\text { integrated the facade } \\
\text { of entrance as an } \\
\text { independent } \\
\text { component. }\end{array}$ \\
\hline
\end{tabular}

Note. The purpose of this table is to explore the photovoltaic applications of different building types. Most of Project data and information of the PV-UP-SCALE consotium and IEA PVPS Task 10.Some projects marked by * are retrived from Hermannstofert. Rub, C. (2005).Solar Design:Phtovoltaics for Old Buildings, Urban Space, Landscapes.
Appendix C

Table 3

\begin{tabular}{|c|c|c|c|c|c|}
\hline \multicolumn{3}{|c|}{ Technical and architectonic aspects } & Thin film modules (rigid) & $\begin{array}{l}\text { Thin film modules } \\
\text { (micror-crystalline, } \\
\text { flexible) }\end{array}$ & $\begin{array}{c}\text { Crystalline silicon modules } \\
\text { (rigid) }\end{array}$ \\
\hline \multicolumn{3}{|l|}{ Typical products } & \begin{tabular}{|l} 
Nanosolar SolarPlyTM \\
(Nanosolar.US) \\
www.nnanosolar.com
\end{tabular} & 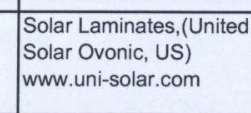 & $\begin{array}{l}\text { Sunways Solar Module SM } 170 \\
\text { U, } \\
\text { polycrystalline,(Sunways,Gema } \\
\text { nvy www sunways com }\end{array}$ \\
\hline \multicolumn{3}{|l|}{$\begin{array}{l}\text { Photovoltaic } \\
\text { technologies }\end{array}$} & $\begin{array}{l}\text { CoTe, a-Si, A-Situc-Si } \\
\text { ITandem, CIGS }\end{array}$ & Amorphous silicon (a-si) & 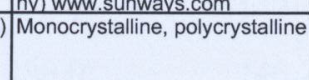 \\
\hline \multirow{13}{*}{ Architectural } & \multirow{4}{*}{ Form making } & Fixed angles & $\begin{array}{l}\text { Fit. This approach is more } \\
\text { sutiable for optimizing } \\
\text { electricity output with rigid } \\
\text { thin film modules. }\end{array}$ & $\begin{array}{l}\text { Portable. Low efficiency } \\
\text { is the maxar irssue } \\
\text { lurrenty when } \\
\text { integrated into buildings. }\end{array}$ & $\begin{array}{l}\text { Fiti.Perormancen price ratio is } \\
\text { the best, recentity compared } \\
\text { with thin flim }\end{array}$ \\
\hline & & Tracking system & 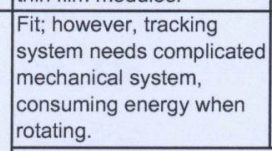 & $\begin{array}{l}\text { Fit. Low efficieincy is is the } \\
\text { major issue currenty } \\
\text { when integrated into } \\
\text { buildings. }\end{array}$ & $\begin{array}{l}\text { Fit. Heavy supporting structure } \\
\text { needs to be considered. }\end{array}$ \\
\hline & & & $\begin{array}{l}\text { MII researchers are testinn } \\
\text { propose a tinted glasss, fun } \\
\text { around its edges. These ph } \\
\text { curtain walls, and skylights }\end{array}$ & 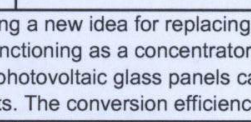 & 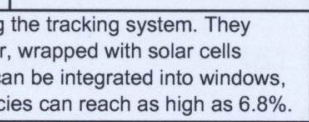 \\
\hline & & Mixed angles & $\begin{array}{l}\text { Need to consider the form' } \\
\text { sangles of curve, and the } \\
\text { size of module }\end{array}$ & $\begin{array}{l}\text { Low efficiency is the } \\
\text { maij issue when } \\
\text { integrated into buildings. }\end{array}$ & $\begin{array}{l}\text { Forr's curve needs to be } \\
\text { careffllly considered, in } \\
\text { cooperation with engineers }\end{array}$ \\
\hline & \multirow{3}{*}{$\begin{array}{c}\text { suitable building } \\
\text { components }\end{array}$} & Roofs & Suttable & \begin{tabular}{|l}
$\begin{array}{l}\text { Suitable, some products } \\
\text { such as solar shingles } \\
\text { can be intergated into a } \\
\text { roof coverere with } \\
\text { rtaditional tiles }\end{array}$ \\
\end{tabular} & Suitable \\
\hline & & \begin{tabular}{|l} 
Windows \\
\end{tabular} & $\begin{array}{l}\text { Not suitable because of } \\
\text { the opaque materials }\end{array}$ & \begin{tabular}{|l|}
$\begin{array}{l}\text { Suitable for windows } \\
\text { integration }\end{array}$ \\
\end{tabular} & Not suitable \\
\hline & & Others & \begin{tabular}{|l} 
Suitable \\
Suitable for independent \\
landscape components \\
such as bus stop canopies
\end{tabular} & \begin{tabular}{|l} 
Not suitable \\
Suitable generally for \\
curved surfaces such as \\
soof tiles; some \\
transparent products are \\
suitable for interior.
\end{tabular} & $\begin{array}{l}\text { Suitable } \\
\text { Suitable for landscape } \\
\text { structures }\end{array}$ \\
\hline & \multirow{4}{*}{ Visual elements } & Transparency & $\begin{array}{l}\text { Semi-transparent or } \\
\text { opaque }\end{array}$ & $\begin{array}{l}\text { Semi-transparent or } \\
\text { opaque }\end{array}$ & 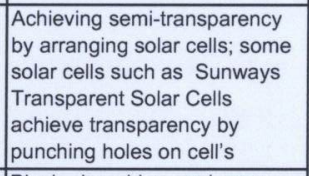 \\
\hline & & Colour & \begin{tabular}{|l} 
Black (CIS), deep blue, \\
and green (CdTe). \\
Colours can be adjusted \\
to new enhanced solar \\
modules while reaching \\
high efficiency (Covalent \\
\end{tabular} & $\begin{array}{l}\begin{array}{l}\text { lack, } \\
\text { brown(amorphous } \\
\text { silicon) }\end{array} \\
\end{array}$ & Black, deep blue, and green. \\
\hline & & Material weight & \begin{tabular}{|l|}
$\begin{array}{l}\text { Range from } 20 \text { to } 30 \\
\text { kg/panel }\end{array}$ \\
\end{tabular} & $\begin{array}{l}\text { Range from } 5 \text { to10 } \mathrm{kg} / \\
\text { piece, some products }\end{array}$ & Range from 20 to30 kg/ panel \\
\hline & & Cover materials & Necessary & 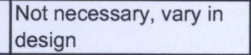 & Necessary \\
\hline & \multirow[t]{2}{*}{ Collaboration } & \begin{tabular}{|l} 
panel changeable \\
or cut to size
\end{tabular} & & \begin{tabular}{|l|}
$\begin{array}{l}\text { eenerarly,y products } \\
\text { have their own } \\
\text { dimensions . The size of } \\
\text { panels can be adjusted }\end{array}$ \\
\end{tabular} & $\begin{array}{l}\text { Some products can be cut to } \\
\text { size. }\end{array}$ \\
\hline & & \begin{tabular}{|l} 
Collaboration with \\
professional
\end{tabular} & $\begin{array}{l}\text { Manufacturers, structural } \\
\text { engineers }\end{array}$ & & \begin{tabular}{|l|l} 
Manufacturers, structural \\
engineers
\end{tabular} \\
\hline \multirow[t]{3}{*}{ nical } & \multirow{3}{*}{ Structural issues } & Detail design & $\begin{array}{l}\text { Gernally provided by man } \\
\text { distinctive dema }\end{array}$ & $\begin{array}{l}\text { nufacturers, detail design is } \\
\text { ands on solar panels. Case }\end{array}$ & $\begin{array}{l}\text { s needed when architects have } \\
\text { study: the GreenPix }\end{array}$ \\
\hline & & structural support & $\begin{array}{l}\text { Need strong structural } \\
\text { supporit such as } \\
\text { aluminum, steel }\end{array}$ & $\begin{array}{l}\begin{array}{l}\text { Relatively simple, can } \\
\text { be antached on the roof } \\
\text { or structures }\end{array} \\
\end{array}$ & $\begin{array}{l}\text { Need strong structural support } \\
\text { such as aluminum, steel }\end{array}$ \\
\hline & & $\begin{array}{l}\text { difficutitises in } \\
\text { asssembly }\end{array}$ & Easy & Easy & Easy \\
\hline
\end{tabular}




\begin{tabular}{|c|c|c|c|c|c|}
\hline \multirow[t]{5}{*}{ | Technical } & \multirow{4}{*}{ Thermal } & insulation layer & \begin{tabular}{|l} 
Need extra insulation layer \\
if installed on facades or \\
roofs
\end{tabular} & 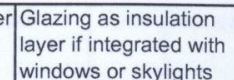 & \begin{tabular}{|l} 
Need extra insulation layer if \\
installed on facades or roofs
\end{tabular} \\
\hline & & $\begin{array}{l}\text { enironmental } \\
\text { temperature }\end{array}$ & \begin{tabular}{|l|} 
Low temperature will \\
increase performance
\end{tabular} & $-45^{\circ}$ to $+85^{\circ}$ & $\begin{array}{l}-45^{\circ} \text { to }+85^{\circ} \text { high temperature } \\
\text { will decrease performance }\end{array}$ \\
\hline & & \begin{tabular}{|l}
$\begin{array}{l}\text { Environmental } \\
\text { numiditity and } \\
\text { wantersenfor }\end{array}$ \\
\end{tabular} & \begin{tabular}{|l|} 
Protection from moisture \\
\end{tabular} & en needed; electrical devic & es should be insulated from rain \\
\hline & & 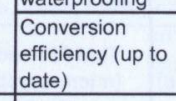 & $6-10 \%$ & $3 \sim 12 \%$ & 6-40\% \\
\hline & & & |Over 25 years & |over 25 years & Oover 25 years \\
\hline
\end{tabular}

\section{Appendix D}

Table 4

Sunrise and Sunset Times for Toronto Eastern Time Zone

\begin{tabular}{ll|llll} 
& & \multicolumn{2}{c}{ Length of day } & \multicolumn{2}{c}{ Solar noon } \\
Date Sunrise Sunset & This day Difference & Time Altitude & Distance \\
& & & & & $\left(10^{6} \mathrm{~km}\right)$
\end{tabular}

Jan 1, 2009 7:51 AM 4:51 PM 9h00m 20s + 48s 12:21 PM 23.4

147.096

Feb 1, 2009 7:34 AM 5:29 PM 9h 55m 04s + 2m 27s $\quad 12: 31$ PM 29.4

Mar 1, 2009 6:54 AM 6:06 PM $11 \mathrm{~h} 12 \mathrm{~m} \mathrm{44s} \mathrm{+} 2 \mathrm{~m} 57 \mathrm{~s} \quad 12: 30 \mathrm{PM} \quad 39.0^{\circ}$

148.248

Apr 1, 2009 6:59 AM 7:45 PM $12 \mathrm{~h} 45 \mathrm{~m} 47 \mathrm{~s}+2 \mathrm{~m} 59 \mathrm{~s} \quad 1: 21 \mathrm{PM} \quad 51.1^{\circ}$

149.511

May 1, 2009 6:10 AM 8:20 PM 14h 10m 40s $+2 \mathrm{~m} 35 \mathrm{~s} \quad$ 1:15 PM $61.6^{\circ}$

150.749

Jun 1, 2009 5:39 AM 8:52 PM 15h 13m 44s $+1 \mathrm{~m} 19 \mathrm{~s} \quad 1: 15 \mathrm{PM} \quad 68.5^{\circ}$

151.704

Jul 1, 2009 5:40 AM 9:03 PM 15h 22m 56s $\quad-40$ s 1:21 PM $69.4^{\circ}$

152.084

Aug 1, 2009 6:07 AM 8:40 PM 14h 33m 21s $-2 \mathrm{~m} 16 \mathrm{~s} \quad 1: 24 \mathrm{PM} \quad 64.2^{\circ}$

151.815

Sep 1.2009 6:41 AM 7:53 PM 13h 11m 13s $-2 \mathrm{~m} 52 \mathrm{~s} \quad 1: 17 \mathrm{PM} \quad 54.4^{\circ}$

150.944

Oct 1, 2009 7:15 AM 6:58 PM 11h 42m 48s $-2 \mathrm{~m} 57 \mathrm{~s} \quad 1: 07 \mathrm{PM} \quad 42.9^{\circ}$

149.742

Nov 1, 2009 6:54 AM 5.08 PM 10h 14m 22s $-2 \mathrm{~m} 39 \mathrm{~s} \quad 12: 01 \mathrm{PM} \quad 31.7^{\circ}$

148.452

Dec 1, 2009 7:31 AM 4:42 PM 9h 10m 20s $-1 \mathrm{~m} 27 \mathrm{~s} \quad 12: 07 \mathrm{PM} \quad 24.5^{\circ}$

147.498

Note. All times are in local time for Toronto (Eastern Time Zone). Data retrieved June, 2008 from Time and Date AS online Sunrise and Sunset Calculator,

http://www.timeanddate.com/worldclock/sunrise.html. 


\section{References}

Addington, M. \& Schodek, D. (2005). Smart materials and technologies. Oxford: Architectura Press.

Bettum, J. (2002, January). Skin deep: polymer composite materials in architecture. Architectural Design. 72. p.72-76.

Capon, D. S. (1999). Architectural theory (Volume Two): Le Corbusier's legacy: Principles of twentieth-century architectural theory arranged by category. New York : John Wiley.

Cericv, Vlatko. Algorithmic art. Retrieved November 11, 2008, from http://www.vceric.net

Chino, Mike. (2008, October). New solar captures entire spectrum of the rainbow. Retrieved

in November 2008, from http://www.inhabitat.com/2008/10/20/new-solar-material-cap tures-energy-from-every-colour-of-the-rainbow/

Colt Group. (2008). PV wall tracks the sun at the Oldenburg stadium EWE-Arena. Retrieved November, 2008, from http://www.coltgroup.com/projects/sports-stadia-leisure/ewearena/

Currie, M. J., Mapel, Jonathan K., Heidel,Timothy D., Goffri, Shalom, \& Baldo, Marc A. (2008, July). High-efficiency organic solar concentrators for photovoltaic materials. Science. 321. 226-228.

Fazio, M., Moffett, M. \& Wodehouse, L. (2008). A world history of architecture ( $2^{\text {nd }}$ ed. $)$ London: Laurence King.

Goetzberger, A., \& Hoffmann, V.U. (2005). Photovoltaic solar energy generation. London: Springer.

Green, M. A. (2006). Third generation photovoltaic materials: Advanced solar energy conversion. New York: Springer.

Giovannini, J. (2003). Turbulence House: Steven Holl joins high technology with the prefabricated in northern New Mexico. Architectural digest,60, 138-144.
Hermannsdorfer, I. \& Rub, C. (2005). Solar design: Photovoltaic materials for old buildings, urban space, landscapes. Berlin: Jovis.

Himanshu, D. (2004). A numerical and experimental study for generation of electric and thermal power with photovoltaic modules embedded in building facade. Concordia University. Masters Abstracts International, 43/03, p.914, 2005.

Hindrichs, D. U. \& Daniels, K. (Eds.). (2007). Plusminus $20^{\circ} / 40^{\circ}$ latitude : Sustainable building design in tropical and subtropical regions. Stuttgart: A. Menges.

International Energy Agency (IEA). (2007). PVPS Annual Report. Fribourg, Switzerland: IEA PVPS.

Jeska, S. (2007). Transparent plastics: design and technology. Basel, Boston: Birkhäuser KieranTimberlake.(2008). SmartWrap ${ }^{\mathrm{TM}}$ : Building Envelope of the Future. Retrieved November 20, 2008, from http://www.kierantimberlake.com/research/smartwrap_ research_1.html

London SE1 website team. (2008, March). Solar panels at City Hall - are they worth the money? Retrieved November 11, 2008, from http://www.london-se1.co.uk/news/ view/ 3176

Luque, A. \& Hegedus, S. (Eds). (2003). Handbook of photovoltaic science and engineering. Hoboken, NJ: Wiley.

Markvart, T. \& Castaner, L. (2003). Practical handbook of photovoltaic materials fundamentals and applications. New York: Elsevier Advanced Technology.

Pearson, C. A. (2006,June). Antoine Predock rides high with the gold medal. Architectural Record, 6. pp. 212-213.

Speck, L. W. (2007).Technology, sustainability, and cultural identity. New York: Edizion Press 
Steadman, P. (2008). The evolution of designs: Biological analogy in architecture and the applied arts (revised ed.) New York: Routledge.

Smith, N. J., Merna, T., \& Jobling, P. (2006). Managing risk in construction projects.

Ternoey, S. (2003). Diffusion of innovations $\left(5^{\text {th }}\right.$ ed.). New York: Free Press.

Time and data AS. (2009). Sunrise and Sunset Calculator. Retrieved September 15, 2009, from http:// www.timeanddate.com/worldclock/sunrise.html.

Western Regional Climate Center. (2008). Climate of New Mexico. Retrieved in November 10 , 2008, from http://www.wrcc.dri.edu/narratives/NEWMEXICO.htm

Wieditz ,T. (2007). Liberty Village: The Makeover of Toronto's King and Dufferin Area.

Retrieved in May 20, 2009, from http://www.urbancentre.utoronto.ca/pdfs/research bulletins/CUCSRB32-WieditzJan07.pdf 